Portland State University

PDXScholar

$1-1-1979$

\title{
An exploratory analysis of the response of urban police to labor radicalism
}

Dennis Earl Hoffman

Portland State University

Follow this and additional works at: https://pdxscholar.library.pdx.edu/open_access_etds Let us know how access to this document benefits you.

\section{Recommended Citation}

Hoffman, Dennis Earl, "An exploratory analysis of the response of urban police to labor radicalism" (1979). Dissertations and Theses. Paper 408.

https://doi.org/10.15760/etd.408

This Dissertation is brought to you for free and open access. It has been accepted for inclusion in Dissertations and Theses by an authorized administrator of PDXScholar. Please contact us if we can make this document more accessible: pdxscholar@pdx.edu. 


\section{AN EXPLORATORY ANALYSIS \\ OF THE RESPONSE OF URBAN POLICE}

TO LABOR RADICALISM

by

DENNIS EARL HOFFMAN

A dissertation submitted in partial fulfillment

of the requirements for the degree of

DOCTOR OF PHILOSOPHY

in

URBAN STUDIES

Portland State University

1979

(c) Dennis E. Hoffman, 1979 
TO THE OFFICE OF GRADUATE STUDIES AND RESEARCH:

The members of the Committee approve the dissertation of Dennis Earl Hoffman presented on August 23, 1979.

Don C. Gibbons, Chairman
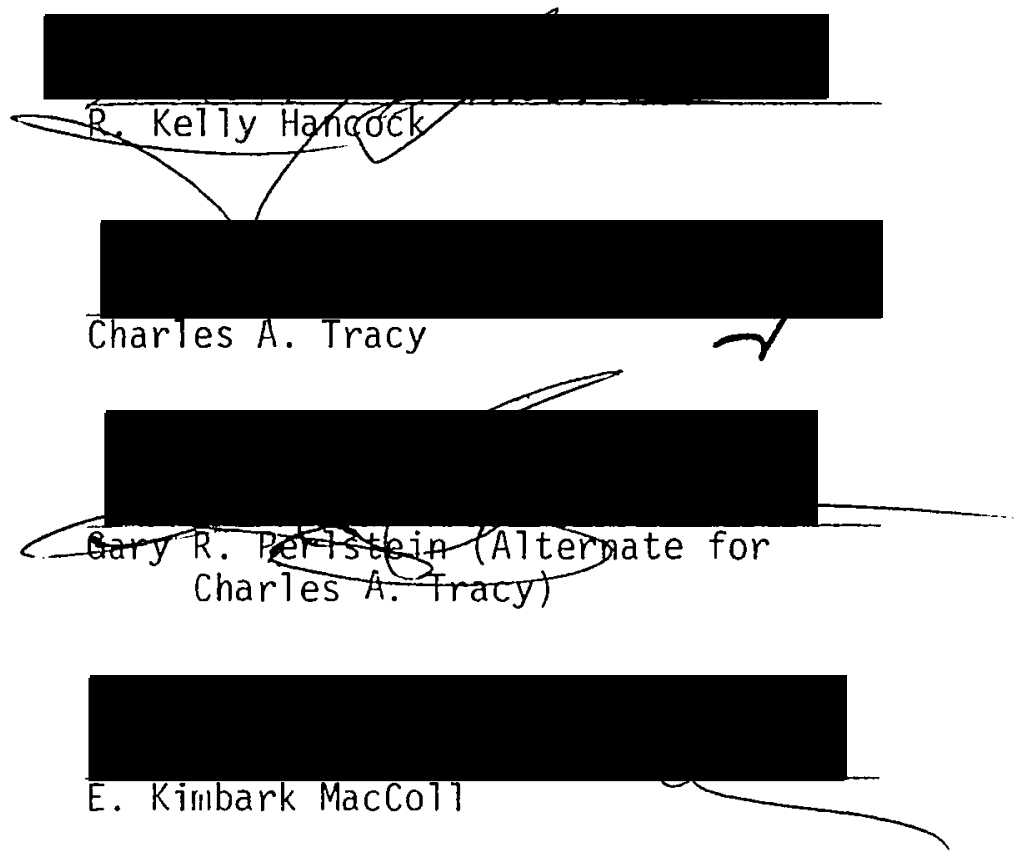

APPROVED:

Charles D. Bolton, Acting Dean, School of Urban Affairs

Stanley Rauch, Dean of Graduate Studies and Research 


\section{ACKNOWLEDGEMENTS}

This dissertation is the product of the combined efforts of a number of individuals. Don C. Gibbons, R. Kelly Hancock, Charles A. Tracy, E. Kimbark MacColl, and Gary R. Perlstein provided the much needed criticism and encouragement; William Appleman Williams, David Horowitz, and David Greenterg furnished the necessary insight and advice; Kathryn Grove added the requisite typing and technical expertise; and Colleen Hoffman supplied the essential love and financiai supporí. I would especially like to single out Don C. Gibbons and R. Kelly Hancock for their contributions. The intellectualism of both of these men served as an exemplary model for an aspiring scholar during three years of doctoral studies. 
TABLE OF CONTENTS

PAGE

ACKNOWLEDGEMENTS ................................

LIST OF TABLES ............................. vi

\author{
INTRODUCTION
}

CHAPTER

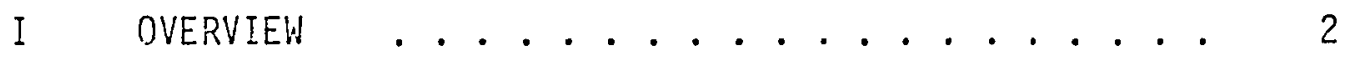

\title{
THEORETICAL FRAMEWORK
}

II A NEO-MARXIAN FRAMEWORK FOR THE ANALYSIS OF THE RESPONSE OF URBAN POLICE TO LABOR RADICALISM . . 17

THEY SHDOT WOBBLIES, DON'T THEY?

III THE SEATTLE AND PORTLAND POLICE AND THE LABOR RADICALS, 1912-1920 ............ 62

IV THE SEATTLE POLICE AND THE POTLATCH RIOTS . . 77

$\checkmark$ ROWDYISM, REFORM, RIOT, AND REPRESSION IN PORTLAND 96

VI POLICE REGULATION OF THE UREETIPLOYED: AN INTERLUDE BETHEEN INDUSTRIAL SKIRMISHES AND CLASS CONFRONTATION .................. 128

VII FROH LOCAL TO NATIONAL CONTROL OF THE CITY POLICE? 145

VIII POLICING THE SEATTLE GENERAL STRIKE . . . . . . 176

IX THE "RED" HUNTING MOVEMENT AND RED SQUADS . . . . 206 
CHAPTER

PAGE

CONCLUSIONS

$X$ CHECKING SOME PROPOSITIONS ABOUT THE POLICING

OF LABOR WARS ............... 240

BIBLIOGRAPHY ................. 264

APPENDIX A . . . . . . . . . . . . 278

APPENDIX B ............................ 280 


\section{LIST OF TABLES}

TABLE

P.AGE

I Vagrancy Arrests Made By Portland Police, $1912-1917$.................. 138 
INTRODUCTION 
CHAPTER I

OVERVIEW

Social Science and Police Studies

Social scientists examining the police role have typically assumed that the individual police officer or department is relatively free to implement social policy as he/she or it sees fit. This assumption is reflected in many police studies which stress the importance of police chiefs, police discretion, and police personalities as being the decisive factors in police behavior. Nonetheless, it is rather incredible that social scientists have believed that a highly stratified society would permit people drawn from the working class such as the police to formulate and to control major social policy. ${ }^{1}$

A more tenable approach to studying the police would be to examine police behavior in terms of the place of the police in class conflict. This approach would focus mainly on how conditions outside of police organizations have shaped police response. Sidney Harring has emphasized the importance of conflict in historical studies of the police:

An historical analysis of the police institution must begin with a specific understanding of power relations, economic interests, and class conflict within particular communities. ... The structure of the police institution, the ways in which it is controlled, and the policies that it adopts change over time as the interests of those in positions of power change. 2 
To date there have been few attempts to systematically collect and analyze data on the police role in any kind of class conflict. A potentially rich area of study involves the police response to the pitched battles fought between labor radicals and the dominant political and economic interests. Two key empirical issues in this area are: 1) What do the police do in times of worker rebelition and revolution? and 2) Why do they act the way that they do?

These type of queries have rarely been subjected to critical examination. Such a task was undertaken in this dissertation. More specifically, this dissertation was an exploratory study of the response of the urban police to labor radicalism. The purposes of the inquiry were to develop a conceptual framework that allowed for a more precise examination of police response than is currently feasible and to apply the framework in a comparative analysis of the responses of the city police in Portland, Oregon and Seattle, Washington to radical labor unrest during the period of 1912-1920. An exploratory approach was necessary because the theoretical work pertaining to police response is not sufficiently developed yet to generate rigorous hypotheses for testing. Additionally, the literature on this subject is limited and widely spread about in articles and books in the fields of labor history, policy history, urban history, criminology and criminal justice; these studies have yet to be combined into a single conceptual scheme. Hence, it was imperative to first systematize the knowledge of the area and to formulate "working" propositions; this made it possible to then conduct a more definitive investigation of the cases of the Portland and Seattle police. 
The product of this approach is a dissertation in three main parts. In part one, a theoretical framework is explicated for the analys is of the police response to labor radicalism. The second part consists of an empirical study of the response of the Seattle and Portland police to the protest and unrest of labor radicals in 1912-1920. Finally, in the concluding section, the theoretical concepts and propositions in the first part of the dissertation are checked in terms of their applicability to the empirical data in the second part.

Construction of a Theoretical Framework

By combining Marxian theory with some empirical evidence from the scattered information on the police and labor, a framework was constructed for the analysis of the police response to labor radicalism. The framework was labeled "neo-Marxian" since it drew heavily from the conceptual work of Roberta Ash Garner, Charles Tilly, Harvey Molotch, and others who have revised and expanded on Marx's writings in the area of political economy and social control. The Marxian theory of class conflict, in particular, was relied upon heavily in the development of the framework. The version of the Marxian theory of class conflict used in this dissertation stresses that conflict between social $\mathrm{classes}$ is rooted in contradictions in the capitalist mode of production. The chief contradiction of capitalism is the contradiction between "socialized production" (i.e., production by a collectivity of workers as opposed to production by individuals) and "capitalist appropriation" (i.e., the owner of the means of production appropriates to himself/herself the 
product and most of the profits derived from it, even though the product was produced through the labor of other persons). This contradiction is manifested in the conflict between the working and the capitalist classes.*

In addition, some ideas in the framework were borrowed from the resource mobilization perspective of llayer Zald, John PlcCarthy, and Anthony öberschall and from the police studies of James Q. Wilson, Jerome Skolnick, Samuel Walker, and Donald Black. The resource mobilization perspective is an approach to the study of social movements which emphasizes the social process by which a discontented group or organization assembles and utilizes resources in the pursuit of collective goals. As for the empirical research on the police that was utilized in the construction of the framework, it pertained to police professionalism, police-community relations, and the mobilization of the law.

The focus of the framework developed in this study was on improving the capacity to foreciell the police response to labor radicalism and on enhancing the understanding of processual relationships between the main conceptua? units. Given the exploratory nature of this study, high precision in prediction and powerfur explanation were neither sought nor achieved. Rather, the conceptual part of the dissertation explicated a theoretical base upon which others can build.

*For a more detailed conceptualization of this version of Marxist theory, see Charles H. Anderson, The Political Economy of Social Class, (Englewood Cliffs, N.J.: Prentice-HalT, Inc., 1974), pp. $46-75$. 
As a whole, the framework was organized in the following way. First, the main units of analysis, namely police response and labor radicalism, were defined. A conceptualization of four pivotal areas of inquiry--linkages between class power, state power, and police response; patterns of labor discontent and police response; community influence on police response; and the factor of the police in police response was then developed. Finally, 22 "working" proposition were stated.

\section{Application of the Framework}

The cases of the Seattle and Portland police and their response to the activities of labor radicals in 1912-1920 were examined in the second part of this research. In light of the fact that the police response to radical labor movements is a relatively unexplored area, the intensive study of these two cases seems to be a useful way to check the propositions in the framework and to stimulate the creation of new propositions.

The discussion of police actions vis a vis labor radicals in Seattle and Portland begins with a broad overview of the organization and functioning of the police in both cities along with a brief description of the Wobblies* and the other labor radicals with whom the police dealt on a regular basis from 1912-1920. This chapter is followed by six chapters which focus on different time periods and explore various facets of the relationship between the police and labor radicals in Seattle and Portland.

*Wobbly is a nickname for a member of the Industrial Workers of the World labor organization. 
It should be stressed at the outset that the type of study conducted in the second part of the dissertation mainily leads to insights; it does not "test" hypotheses. Among other things, the cases of Portland and Seattile may not be entirely representative of the police response to labor radicalism. Other police encounters with labor radicals in other cities, and in other time periods may not have been so intense, colorful, and violent as the clashes between the police and the Wobblies in Seattle and Portland. Then, too, data from only two cases provide an inadequate basis for drawing conclusive generalizations about any kind of social phenomena. Hence, the reader should keep in mind the proviso that more carefully controlled studies will be needed to determine whether the findings that emerged have a more general applicability than for Portland and Seattle and for oniy the period of 1912-1920.

Summary

In this brief introduction it has been contended that a perspective emphasizing class analys is is necessary in order to adequately study the police. Also, it has been suggested that the foundation for this perspective should be Marxian social theory and that many of the building blocks can be drawn together from a number of areas of study. In short, the position taken in this dissertation is that a synthetic, multidisciplinary approach is most useful for inquiries into the police response to labor radicalism.

This chapter also included a delineation of the basic features of a comparative study of police response which constitutes the second part of the dissertation. An unstated, yet implicit point in 
the conduct of this inquiry into the actions of the Seattle and Portland police is that social scientists must perform more empirical analyses of the police as well as other functionaries of the criminai justice system if they are to make more substantial contributions to the understanding of societal reactions to protest, crime, and other forms of social disorder than they have made in the past.

In general, the thrust of this introductory chapter is that there is little solid information on how the police respond to challenges to the social order by labor radicals. Furtherimore, much of what we think we know about the police comes from studies that underestimate the importance of political, economic, and social factors in influencing police behavior. The way to resolve these problems is not for all social scientists to convert to Marxism. Rather, the best approcs seems to be for social scientists to begin to critically grapple with the subject matter in some of these inchoate areas, such as the police response to labor radicalism, which seem to fall between or at the intersections of academic disciplines and intellectual fields. 


\section{REFERENCES--CHAPTER I}

1. John F. Galliher, "Explanations of Police Behavior: A Critical Review and Analysis," in Arthur Niederhoffer and Abraham S. Blumberg (eds.), The Ambivalent Force, Second Edition (Hinsda7e, 111.: The Dryden Press, 1976), pp. 65-72.

2. Sidney Harring, "The Development of the Police Institution in the United States," Crime and Social Justice 5 (SpringSummer, 1976), p. 58 . 
THEORETICAL FRAMEWORK 


\section{CHAPTER II}

\section{A NEO-MARXIAN FRAMEWORK FOR THE ANALYSIS OF THE RESPONSE OF URBAN POLICE TO LABOR RADICALISM}

\section{Definition of Terms}

Those who have investigated police encounters with labor organizations largely have ignored the problems associated with defining key terms. These scholars have been more given to narrating and recorjing police involvement in labor conflicts than to dissecting the conceptual units used in their analyses. Yet, some attention must be paid to definitional matters in the study of police-labor interaction. "Police response" and "labor radicalism" are two terms that must be defined before one can even commence a Sefious exploration of the police and labor.

Let us begin with police response. This term embraces both the mobilization of resources by the police and the collective and individual actions of the police. The distinction between mobilization and collective action should be underscored. Police mobilization involves the process of acquiring and marshalling resources needed for action. An example of the mobilization of resources would be the police petitioning the city council to authorize the hiring of more police officers for the purpose of maintaining order at demonstrations. 
The mobilization of the police can be broken down into these components: a) accumulating resources (e.g., labor power, weapons, goods, etc.) and b) increasing claims on resources. These components apply to the mobilization of any group. ${ }^{1}$ Accumulating resources consists of aggregating manpower, money, and other resources in a police department. The second component includes reducing competing claims on resources, altering the organization's program of action, and making police workers more satisfied with their job in order to build commitment to the police occupation.

Besides mobilizing resources, the police may use resources and act together in the pursuit of a set of interests. Collective action by the police can be analyzed on three levels: policy, strategy, and tactics. Like other authorities, the police take at least three policy stances vis a vis labor and other contenders for power. These are: a) facilitation; b) toleration; and c) repression. ${ }^{2}$ A policy of facilitation lowers the contenders' costs for mobilization and collective action and makes it easier for the contenders to achieve their goals. An example of a facilitative policy would be the disarming of strikebreakers by the police. When a policy of toleration is in operation, the police are neutral and impartial in their actions. Allowing strikers to picket while at the same time protecting strikebreakers exemplifies a tolerant police policy.

Repression merits special consideration since it is a term that frequently has been used to describe police behavior in situations of conflict between the forces of capital and labor. With a repressive policy, the police check, subdue, or put down labor unrest 
through the use of force or other types of pressure. If the police are bent on repressing radical labor or other contenders for power, they have the option of working on an organization's mobilization processes or on its collective action. ${ }^{3}$ Measures such as suspending newspapers and forbidding assemblies exemplify the anti-mobilization approach. Enforcing court orders which outlaw particular organizations and arresting participants in demenstrations are ways of raising the costs of collective action.

With regard to police strategy, police organizations possess certain general ways of coping with the crime problem. Policing strategies refer to an orientation toward allocating resources to afford the maximum support to police policy. Peter llanning and John Van Maanen among many others have identified "reactive," "proactive," and "preventive" strategies as being basic forms of police work. ${ }^{4}$ Reactive strategies are the most commonly employed by the police. ${ }^{5}$ In these, the police respond to a citizen complaint after the crime or the trouble has already occurred. Conversely, police action happens prior to or simultaneously with crime commission in proactive strategies. Proactive police strategies are initiated by the police themselves. The utilization of decoys and drug raids are two examples of proactive police work. Preventive strategies are similar to proactive ones in terms of the timing of police action. Yet they differ from proactive strategies in that preventive strategies are geared toward anticipated acts of 1 awbreaking. The hardening of the potential targets of criminals through the use of locks, alarms, and other hardware is a prime example of a preventive strategy. 
How do policing strategies relate to labor unrest? Basically, law enforcement personnel use the same strategies to police conflict between capital and labor except that in dealing with labor they may prohibit or prevent citizens from behaving in legal ways, whereas in fighting crime they control and/or prevent cit:zens from behaving in illegal ways. The work of reserve and auxiliary police reflects a reactive strategy for handling labor disturbances. These police wait until a labor disturbance breaks out before taking action. Regular or full-time police can also be reactive in responding to calls for assistance from either labor or management. Proactive strategies are exemplified by police raids on labor union halls and policeinitiated riots that disrupt or end meetings of workers. Intelligence gathering operations that are geared to allow the police the opportunity to forestall, defuse, or delimit the actions of labor and/or management and special police activities that are aimed at controlling working class youth are representative of preventive strategies.

Tactics are another aspect of police response. A poiice tactic is a specific method for accomplishing an intended effect. Some examples of tactics that have been used in situations involving labor are as follows:

1. Isolate and ignore protesting workers.

2. Divide off areas that might be used by workers to meet, to protest, etc.

3. Deny workers access to an area.

4. Disperse workers at a rally or other gathering.

5. Arrest leaders at a gathering of workers. 
6. Search premises without warrants and arrest workers on suspicion.

7. Assault and/or shoot participants in meetings, riots, demonstrations, etc.*

Turning to "labor radicalism," it also must be addressed in specific terms. Historically, radicalism has been the exception rather than the rule over the course of labor relations in the United States. Reformism ia: been the normal course of labor affairs as union representatives have adjusted to the prerogatives of capitalist management and have been interested mainly in piecemeal, pragmatic gains rather than in drastic social change.

In spite of the reformist character of the labor movement, there have been roughly three phases of labor radicalism in the United States. ${ }^{6}$ The first phase extended from around 1870 until the early years of the twentieth century. A hodgepodge of industrial armies, working class political parties, industrial quasi-unions, and anarchist groups formed the backbone of this first current of labor radicalism. The marches for jobs and food as well as the other agitational activities of these pro-labor collectivities often were crushed by the combined power of the militia, federal troops, private vigilantes, and city police.

The second phase of labor radicalism started around 1909 and continued through World War I. Labor radicals, who were active in this phase, sought to replace the capitalist system with a cooperative

*!lany of these examples have been borrowed from Raymond $M$. Momboisse's Riots, Revolts, and Insurrections (Springfield, Mass.: Charles C. Thomas Publisher, 1967) and modified to fit the situations in which the police and labor radicals have encountered one another. 
or socialist system. The: Industrial Workers of the World (I.W.W.) stands out as the archetype of working class radicalism in this period. The I.W.W. held that any step taken by the workers at the point of production that improved wages, reduced hours, or otherwise brought about a transfer of power from the dominant class to the working class should be a vital part of labor's arsenal. Direct action took a variety of forms, including free-speech fights* and general strikes. ${ }^{\star *}$ The ferment of radical activities in this period was snuffed out, in part, by the actions of federal, state, and local police forces.

The third phase of labor radicalism followed on the heels of the Depression when workers in the mass production industries formed industrial unions. Their efforts in various cities coalesced in the organizing drive of the Congress of Industrial Organizations (C.I.0.). Formed in 1935, the C.I.0. involved approximately half a million workers in "sit down strikes"*** and organized about four million workers into unions in the years 1936-1937. By the end of World War II,

* Free speech fights consisted of Wobblies standing on top of soap boxes or on street corners, haranguing working class crowds about the inequities of capitalism. Police attempts to stop Wobbly speakers often were foiled because as soon as one speaker was taken into custody another would take his or her place in spouting ideas on the injustice of a private property system.

**The I.W.W.'s notion about a general strike was that when a sufficient number of workers had been organized, it would be possible to seize an entire industry by striking.

$\star \star \star$ In a sit down strike the workers stop work but stay in the workplace instead of picketing outside of the plant or mill. 
however, the militancy of the C.I.0. had faded. The police appear to have been connected with the demise of C.I.0. radicalism just as they were with the termination of other forms of labor radicalism in earlier phases.*

Generalizing from these three phases of radicalism in the labor movement, labor radicalism may be defined as a nonconventional, militant approach to economic and industrial problems characterized by extreme dissatisfaction with the status quo. This definition is stated in general terms in order to encompass the actions of labor radicals in all three phases. It must be recognized that this definition stresses the approach or the method used by labor radicals to achieve their goals. This emphasis upon "means" in defining radicalism is in contrast to the usual emphasis that has been placed upon "ends." Typically, social scientists have defined radicalism as a desire to make extreme or fundamental changes in the social structure of society.

With regard to the phenomenon of labor radicalism, the traditional attention paid to ends does not seem to be entirely appropriate because the repertoires of action of early pro-labor collectivities, the I.W.W., and the C.I.0. appear to be the most useful characteristic in distinguishing labor radicalism from labor reformism. In point of fact, it seems that the most significant difference between labor radicals and labor reformers has been that the marches, general

*The deradicalization of the C.I.0. also was partially due to the C.I.0.'s own organizational goals and its relationship to big business and government. For a more complete discussion of this point, see C. Wright Mills, The New Men of Power (New York: Harcourt Brace Jovanovich, Inc., 1948). 
strikes, and sit-down strikes of the radicals have taken place outside of the acceptable limits of protest, whereas most of the practices and actions of the A.F.L. and other reformist organizations have occurred within institutionally legitimate channels. This emphasis on means rather than ends is not meant to discount the anarchist, syndicalist, socialist, and communist ideas have been part of the thinking of labor radicals; instead, this emphasis is necessary in order to capture the actual importance of action in the history of labor radicalism.

\section{Linkages Between Class Power, State Power, and Police Response}

In analyzing the police response to labor radicalism it is imperative to include a theoretical conceptualization of the police function. In general, the police function in the United States has been described in police studies as consisting of the components of "order maintenance" and "law enforcement." The former term refers to peace-keeping activities, while the latter relates to crimefighting activities. James Q. Wilson was the first social scientist to identify these two functions as being central to the police role. ${ }^{7}$ Numerous other classification schemes have been devised to capture the essence of the police function since the pubtication of his Varieties of Police Behavior, but most of these differ only slightly from Wilson's original work.

In terms of the sources of influence on the police, a substantial portion of the police literature has been devoted to examining phenomena such as discretion, subcultural values, attitudes, administrative ethos, and styles of police work which pertain to law 
enforcement personnel and organizations.* In addition, the idea that the police are subjected to pressures from a host of special interests has been a standard feature of most of the theoretical work on the police. The influence of political parties and racketeer orgarizations has often been stressed in this regard, while the power of legitimate economic interests over the police has been given short shrift by conventional or non-Marxist scholars. Still another common feature of police studies is the recognition that the police operate in a governmental framework whose purposes are diffuse and often contradictory. This is held to be the case because a variety of public institutions operating at different levels of government and possessing conflicting goals have some influence on the police role.

A Marxian position on the police function is similar to the traditional perspective in some ways, yet markedly different from it in other respects. ifarxists, while conceding that there is a large amount of routine peace-keeping involved in policing, maintain that the requisite of defending the class system is at the heart of the police function. Stated another way, a Marxian conceptualization of the police posits that the class system is at the core of capitalist society protected, in part, by the armor of the state through the capacity of the police to use force. ${ }^{8}$

What is most unique about a ilarxist analysis of the police is that class relations are singled out as being the preeminent force involved in the structuring of the police function. From a Marxist

*A useful summary of some of the most important studies on these topics can be found in Don C. Gibbons' Society, Crime, and Criminal Careers, 3rd ed. (Englewood Cliffs, N.J.: Prentice-Hall, 1977), pp. 49-78. 
perspective, social classes are largely determined by the productive relations into which human beings are either born or enter with little freedom of choice. ${ }^{9}$ Crucial, insofar as the police function is concerned, are the relations among social classes and the relations between specific classes, the government, and the police. The pivotal ideas of Marxian social theory can be developed more concretely by examining some of the ways of looking at the relationship between the capitalist class, city government; and police response to labor unrest. To begin with, it appears that police intervention has been to the detriment of labor and to the benefit of the capitalist class. A review by Philip Taft and Philip Ross of American labor-management disputes makes it clear that the police, troops, and plant guards have done the bulk of the killing and wounding. In a sketch of the usual circumstances in which persons died in labor violence during the nineteenth and twentieth centuries, Taft and Ross summarized their findings in these words:

Facing inflexible opposition, union leaders and their members frequently found that nnthing, neither peaceful persuasion nor the heads of gc rernment, could move the employer towards recngnition. Frustration and desperation impelled pickets to react to strikebreakers with anger. Many violent outbreaks followed efforts of strikers to restrain the entry of strikebreakers and raw materials into the struck plant. Such conduct, obviously illegal, opened the opportunity for forceful police measures. In the long run, the employer's side was better equipped for success. The use of force by pickets was illegal on its face, but the action of the police and company guards were in vindication of the employer's rights. 10

Why have the police so often sided with the capitalist class? A number of studies have addressed this question. In some cases, the 
question is at least implicitly raised, but no evidence is presented to resolve it. Melvyn Dubofsky's treatment of the response of the Paterson, New Jersey police to the I.W.W., 11 indicated that the police arrested three I.W.W. leaders and closed every hall in town to the strikers only one day after the start of the city's silk mill strike. The next day the police arrested Frederick Sumner Boyd, a socialist, for having read the "free speech clause" of the New Jersey state constitution at a strike meeting. When Police Chief Bimson asked Boyd what law he had been reading, Boyd informed him: "Why chief, that was the Constitution of New Jersey."12 Moreover, during the same strike, Big Bill Haywood, the fabled I.W.W. leader, was denied the right to speak in Paterson by the police. Haywood and approximately 1,000 men and women marched to Haledon, a smal1 township outside of Paterson, in order to hold a meeting. A few feet short of the Haledon line, the marchers were met by the Paterson police who improperiy arrested Haywood and another I.W.W. member for disturbing the peace, acting disorderly, and holding an unlawful assembly.

Dubofsky depicted the police as acting in accordance with the interests of the employing class. Still, the reader is left up in the air over the burning question of, "what forces influenced the police to behave the way that they did?" Did the police receive their marching orders from a mayor who was beholden to the capitalist class? Were some of the police under tine employ of the mill owners? Dubofsky never tells us. 
Explanation by accusation is another way of dealing with the relationship between the capitalist class and the police. Wyndham Mortimer's description of the "Battle of Bulls Run" in 1937 between the officers in the Flint, !lichigan police department and the members of the United Auto Workers Union exemplifies this approach. ${ }^{13}$ According to Mortimer, the Flint police precipitated the first violence during a sit-down strike when they stopped a truck carrying food to the strikers inside Fisher Plant Number Two. Next, the police attempted to force their way into the plant, thus starting the "Battle of Bulls Run." The strikers inside the plant responded by drenching the police with high-pressure fire hoses and by pelting them with bottles, automobile door hinges, and other objects. After several charges by the police and six hours of water-fighting by the strikers and some gun-play by the police, the flint police withdrew from the scene.

The reason for the police behavior in the "Battle of Bulls Run," in Mortimer's view, was the the police and the entire city government were "subservient" to the General Motors Corporation. 14 Rather than supporting his explanation by limning the facets of the relationship between the police and General Motors, Mortimer allowed his accusation to stand unsupported.

A third approach to studying the influence of the capitalist class on the police might be termed the "personnel-overlap view." Proponents of this view hold that the linkages between the economically dominant class and the state lie in particular positionholders. ${ }^{15}$ sidney Harring and Lorraine :ICMullin utilized this 
approach in their investigation of the Buffalo, New York police. ${ }^{16}$ They argued that the business-related occupational backgrounds of the mayors and police commissioners in Buffalo accounted for the police repression of labor unrest.

By itself this approach provides oniy a partial resolution to the issue under consideration. Once the investigator ascertains that the position-holders are members of the dominant class, he/she still must examine their behavior in regard to issues and conflicts in order to determine whether or not power was actually exercised in accordance with material interests. Then too, the researcher must also find out how often the position-holders have been successful in overcoming opposition from other groups. 17

Despite the limitations of the personnel-overlap approach, it is very useful in ferreting out the material interests of those who are responsible for the formulation of police policy. Hence, the following proposition seems suitable for exploration:

I. Police policy-makers, who have business occupational backgrounds, are predisposed to favor a policy of repression of labor radicalism.

A fourth way to look at the relationship between the capitalist class and the police is to search for ideological convergence between the two. This approach assumes that if the police and the dominant class share the same attitudes, then police actions will benefit the capitalist class. A prime example of this approach can be found in Herbert Gutman's inspection of the causes of the Tompkins Square Riot in New York City in 1874. ${ }^{18}$ The New York police, under the 
direction of conservative businessmen and powerful political figures who were serving as Police Commissioners, attacked a rally in Tompkins Square of workers who were calling for enlarged public works to aid the increasing numbers of jobless workers. Gutman reported that mounted police charged the peaceful gathering of workers repeatedly, riding down and clubbing men, women, and children in a very brutal display of the abuse of police power.

To explain the riotous behavior on the part of the police, Gutman stressed police attitudes toward urban workers. His thesis was that both the police and the propertied urban classes adhered to the belief system of laissez-faire capitalism. One drawback of Gutman's work is that he did not provide any evidence that the rank-and-file police who administered the beatings to workers subscribed to the notions of a free market and individualism and opposed the concept of public responsibility. Instead he presented only pro-capitalism statements from high ranking police officials and newspaper reporters. In addition, Gutman neglected to identify the criteria he used for deciding that ideology was the crucial factor underiying police behavior. Although he indicated that the Police Board was mainly comprised of wealthy entrepreneurs and powerful political figures, Gutman implicitly relegated material interests to secondary importance and elevated ideology to the level of being the primary cause of the riot without providing a justification for his choice.

Notwithstanding the pitfalls of the ideological convergence approach, it seems plausible that: 
II. The more similarity between the belief systems of line police officers and the capitalist class, the more likely that the police will implement a policy of repression of labor radicalism.

In addition to these first three approaches to the study of the relationship between police behavior and the capitalist class, there are other ways in which the interests of the dominant class can influence police response. The political party affiliation of elected officials in city government is another bridge between the capitalist class and police operations. ${ }^{19}$ Political parties have served as mechanisms through which both the capitalists and the workers have sought to control the mayor's office and the city council. Controlling these areas, in turn, has meant that a social class possibly could exert influence on the police since the mayor in many cities has had the formal responsibility of making police policy and the city council has typically allocated resources and drafted ordinances defining illegal conduct.

With regard to the Democratic Party, Roger Lane indicated that there was a split on the Boston City Council in 1878 over the practice of allowing police officers to be contracted out to employers during strikes. ${ }^{20}$ Lane reported that the workers' influence in the Democratic Party was responsible for the divisions on the Council.

The working class had a fairly strong hold over the police and other municipal agencies in cities where the Socialist Party was powerful in the first part of the twentieth century. James Weinstein found that in 1912 alone Socialists held "some 1200 public offices in 340 municipalities from coast to coast, among them 79 mayors in 24 
states."21 One of the distinguishing marks of these socialist-run cities was the curbing of police hostility toward strikers. The city government of :1i lwaukee, Hiscons in in 1910-1911 is an example of worker influence on police practices. Labor gained access to the police when Emil Seidel, a Socialist, and a Socialist-dominated administration were elected to office in 1910. During his term as mayor, Seidel made it a point to see that the police respected strikers' rights. 22

As for the Republican Party, it has commonly been presumed that police operations are most likely to favor the capitalist class when the Republican Party dominates city government. However, studies that support this assumption are difficult to uncover. In fact, Gutman found that a Republican mayor refused to heed the demands from the business community to suppress labor disorders in Paterson, New Jersey in the 1870s. ${ }^{23}$ Moreover, the findings from Harring and Mcilution's study of Buffalo police seem to show that political party was not an important determinant of police behavior. ${ }^{24}$ Instead, they asserted that political power shifted between Republicans and Democrats regularly, but power was always held by businessmen and police response was always somewhat repressive.

In vielw of the findings from these empirical studies, a rather pessimistic assessment of the effects of the major political parties on police policy seems in order. This assessment can be expressed in the form of a "nu11" statement.

III. There will be no major differences between the police policy pertaining to radical labor in a Republican-controlled municipal administration and police policy in a Democratic-controlled municipal administration. 
Another linkage between class interests and the police derives from the way that municipal government is structured. Cyril Robinson presented a sophisticated explanation of why the police, who have been drawn from the working class, supported labor at times in the nineteenth century, but were so often used by the capitalist class to put down strikes and other types of action sponsored by the working class in the twentieth century. 25 According to him, at one time the working class, through its ability to capture electoral majorities, was able to exert considerable influence on the mayor and, in turn, on the police who were under the mayor's authority. Robinson took the position that the structural aspects of police reform contributed to the tendency of the police to side with the capitalist class. Specifically, he stated that the creation of civil service and administrative police boards weakened the control of the mayors over the police and, in effect, insulated the police from the working class. Robinson's explanation is supported in James Richardson's analysis of civil service, municipal reform, and the police. 26 Richardson cited civil service, the city manager and commission forms of government, and at-large elections as all reducing the capacity of the working class to direct police actions.*

*The working class did not passively allow their political power to be taken from them. In the early 1900s Socialists opposed attempts to institute city manager or comission forms of government and attempts to substitute nonpartisan city-wide elections for ward-based elections to city councils and school boards. For a more complete description of working class resistance to the municipal reform movement, see Bruce Stave (ed.), Socialism and the Cities (Port Washington, N.Y.: Kennikat Press, 1975). 
Based on the thinking of Robinson and Richardson, it can be expected that:

IV. The process of institutionalizing reforms in municipal government promotes a police policy of repression of labor radicalism.

Up to this point, the discussion has dwelled upon the dependence of municipal government on class interests. This is only a partial explanation of the relationship between class and state power. A first step toward a more flexible description of the interplay of class and state interests is to realize that municipal authorities may possess and exercise power that is relatively independent of the capitalist class even though the general purpose of the state is to preserve the coherence of capitalist society as a whole. Stated another way, there are times when the political power of the state is "endowed with a movement of its own." 27

Andrew Hopkins has gone so far as to state that big business has had to give ground to "other" interests under some circumstances. $\star 28$ He made this assertion in connection with a discussion of the problem of accounting for criminal laws such as antitrust laws which are inimical to the interests of powerful groups. According to Hopkins, the way to deal with this problem is simple--admit that business interests can be and sometimes are over-ridden by other classes, organizations, and institutions. ${ }^{29}$

*Stephen D. Krasner's interpretation of U.S. oil policy toward the Middle East supports the view that the state can be an autonomous force. Krasner's analysis of four select episodes involving the U.S. government in the !1iddle East during the period of 1951 through the 1970s indicated that the government has endorsed policies that have been opposed by the oil industry. For a more detailed account of the state as an autonomous entity, see Stephen D. Krasner, "A Statist Interpretation of American 0il Poijcy Toward the Middle East," Political Science Quarterly, 95 (Spring, 1979), pp. 77-97. 
This same line of reasoning is applicable to understanding the police response to labor unrest. When one discovers instances where police policy and actions are harmful to the capitalist class, there should be a search for antagonisms between class and state interests.* Clashes between the capitalist class and governmental authorities can be expected to have a moderating effect on police policy. The following relationship between class-state conflict and police response should hold:

V. A high level of conflict between class and state interests promotes a police policy of toleration of labor radicalism.

Patterns of Labor Discontent and Police Response

Collective action by radical labor unions and other organs of the working class has probably affected police organizations and behavior in a variety of ways. For one thing, the modern urban police system in the United States was created partially in reaction to the labor-related disorders of the 1830s, 1840s, and 1850s. Beyond this fact, however, not much attention has been given to studying the ways in which working class organizations have altered the structure and activities of porice institutions.

In part, this void in our knowledge about the impact of working class collective action on the police is due to the "fallacy of elitism"** which is reflected in many police studies. This

*A more fully developed discussion of state activities that may threaten the class system can be found in Roberta Ash Garner's Social Change (Chicago: Rand McNally Publishing Company, 1977), pp. 259-262.

**The fallacy of elitism consists of conceiving human groups in terms of the upper strata. See David Hackett Fisher, Historians Fallacies (New York: Harper and Row, 1970), pp. 230-232. 
fallacy has been prominent in the writings of police experts such as August Vollmer, 0. W. Wilson, and James Q. Wilson. These authors have tended to conceptualize the development of the police in terms of the ability of police administrators to dominate all aspects of police work.

To counteract the elitism in police studies, scholars need to look into the ways in which the power of an insurgent, organized working class can be a determinant of police response. Charles Tilly's observations on the relationship between the power of movement organizations and the actions of authorities provide some insight into this matter. ${ }^{30} \mathrm{He}$ averred that power begets respect from authorities. In other words, if a labor union has a considerable amount of power (i.e., a large membership and/or the ability to exercise major say on issues deemed of importance to its interests), the authorities will at least tolerate the union's activities for fear of incurring losses or costs from confrontations. Conversely, if organized labor is weak, it is likely to receive the "full force of the law."

Data from at least two studies suggest that the type of policy the police follow may be related to the perceived likelihood that labor can apply its resources to make its interests prevail over those of the capitalist class. Claude Hoffman discovered that there was an "amassing" of police during a "reign of terror" against the United Auto Workers' local 663 in Anderson, Indiana in 1937.31 One gets the impression from reading Hoffman's narrative that a sort 
of "Thermidorian reaction"* took place in Anderson at a time of retrenchment for labor following the defeat of local 663's sitdown strike. A similar situation has been described by Gutman in his treatment of the Tompkins Square outrage. ${ }^{32}$ Gutman portrayed the period after the Tompkins Square Riot as one of extreme police repression.

The main theme in the empirical research as well as in Tilly's conceptual work can be expressed in this hypothesis:

VI. A dramatic decline in the power of a radical labor organization can lead to a police policy of repression.

A qualification should be added to this discussion of police response and labor power. Police response may depend on the stability of the political-economic system. While certain policies, strategies, and tactics can be anticipated when a system is stable, other types of police response may occur during a "revolutionary situation." A revolutionary situation or a state of "dual power" might begin when a government previousiy under the control of a single, sovereign polity becomes partially controlled by workers who mobilize into a power bloc that rivals the official government. 33 In a revolutionary situation labor itself may exercise enough control over the state apparatus to determine police policy. Under a state of dual pover, police policy may be markedly different from what it is under usual conditions.

*The term "Thermidor" is the name given to the warmest season of the year by the leaders of the French Revolution. On 9th Termidor of the second year of the French Revolution (1794), the revolutionary leader Robespierre was deposed. The next day he was executed, thus ending one phase of revolution and commencing another phase. The period involving the suppression of radicals has been referred to as the "Thermidorian Reaction." See Leonard Broom and Philip Selznick, Sociology, 5th Ed. (New York: Harper and Row, 1973), p. 599. 
VII. Toleration and/or facilitation are likely to become adopted as police policies in a revolutionary situation.

Moving from poirice policies to police strategies, it should be stressed that social action by the working class may be a decisive force in molding police response. Donald Black's writings on the impact of social conflict on policing strategies provide an idea as to how labor-business conflict may be related to police strategy. ${ }^{34}$ He proposed that "government-initiated" or "proactive" strategies are disproportionately used by police when there is a high level of conflict between the "authority system and those subject to it." 35 According to $\mathrm{Black}$, this is so because proactive strategies contribute more to the perpetuation of systems of social stratification than do "citizen-initiated" or reactive strategies. He asserted that ideally decision-making in the form of citizen complaints cancels itself out in reactive strategies (i.e., citizen complaints are evenly distributed across groups in a stratified order), while a decision by the police to initiate action reflects police biases and to some extent the interests of those in superordinate positions of authority over the police.

With respect to labor-business conflict, some historical evidence lends credence to Black's predictions. The re have been several recorded instances where the police have concentrated on weakening labor's capacity to mobilize resources. For example, the police illegally confiscated a sound truck belonging to the United Auto Workers in Anderson, Indiana during one of the heated battles between the C.I.O. and the auto industry. ${ }^{36}$ Police also worked on labor's ability to 
mobilize resources during the prelude to the Tompkins Square affair in New York. ${ }^{37}$ The New York police first went on the offensive by turning down the parade route proposed by the organizers of the demonstration. Also, the Police Board ordered the patrolmen to arrest anyone trying to persuade workingmen to participate in the parade. After the parade was cancelled and a site was chosen for a street meeting, the Police Board intervened again by convincing the Department of Parks to void the permit to meet in Tompkins Square. Besides these examples of proactive strategy, police raids following the riot influenced workers to stay away from other meetings and organizing drives. All of these proactive efforts by the New York police occurred at a time of intense conflict involving labor radicals and big business.

By translating Black's authority-relations terminology into the language of class analysis and by extrapolating from the data in two related studies, the following proposition has been formulated:

VIII. The higher the level of labor unrest, the more likely it is that there will be an emphasis on proactive strategies.

Reactive strategies are also likely to be employed in times of worker dissatisfaction and agitation. These types of strategies tend to favor the dominant class because the creation and application of many laws that stipulate the forms of behavior that the police must deal with in reactive police work reflect the interests of the capitalist class. The historical record is repleie with instances where the police have enforced "special" laws that were designed to break strikes and to undermine cormunity support for organized labor. 
Criminal syndicalism laws* and city ordinances prohibiting freedom of speech are two blatant examples of these types of laws.

As for the application of laws already in existence, it is important to remember that discriminatory law enforcement is a result of differences in power and that decisions as to whose behavior is criminal are expressions of power. ${ }^{38}$ The extent to which some laws are enforced more frequently or more rigidly in regard to a given social class is, however, an empirical question.

To analyze the process whereby reactive strategies are brought into use, it is beneficial to take the Marxian thesis of the "criminalization of surplus labork* into account. Marxists contend that the capitalist class depends upon the existence of a relatively free, apolitical surplus labor force in order to break strikes and to keep wages low. It follows that attempts by radical labor unions to broaden the scope of their mobilization efforts and, as a consequence, to politicize portions of the surplus labor force are likely to be opposed by the capitalist class. This opposition may be reflected

* Criminal syndicalism laws defined almost every basic tenet of I.W.W. ideology as a crime. Hence, anyone who advocated Wobbly ideas by speech, writing, publication, or display became ipso facto a criminal. For a more complete discussion of criminal syndicalism laws, see Eldridge F. Dowe11, "A History of Criminal Syndicalism Legislation in the United States," The Johns Hopkins University Studies in Historical and Political Science Series, LVII, No. T (Battimore, T939).

**For a more thorough explication of the idea of the "criminalization of the surplus labor force," see Richard Henry Tawney, The Agrarian Problem in the Sixteenth Century (New York: Harper and Row, 1967). Steven Spitzer also stated a brief argument of this kind. See Steven Spitzer, "Toward a Marxian Theory of Deviance," Social Problems, 22, 5 (June, 1975), pp. 638-651. 
in the enforcement of laws covering types of behavior in which some people in the surplus labor force tend to engage. More specifica??y, the police may begin to treat potential union memibers who are also part of the surplus labor force as being criminals in order to impair the mobilization efforts of radical labor.

Sidney Harring conducted one of the few inquiries into the phenomenon of the criminalization of surplus labor. ${ }^{39}$ Harring described how the Buffalo police, acting under the Tramp Acts of 1885, indiscriminately arrested tramps, beggars, hobos, vagrants, unemployed persons, and workers. :lore importantly, he claimed that the Tramp Acts served as a tool for the police to repress Count Rybakowski's tramp army* which appealed to many of the groups whose members were arrested under the Tramp Acts.

Harring and McMulitin's analys is of labor unrest and the efforts of the police to control workers in Buffalo, New York from 1872-1900 contains empirical data that bear on the issue of discriminatory law enforcement. ${ }^{40}$ They discovered that the level of strike activity was positively related to the proportion of laborers arrested as opposed to persons of other occupations. Arrest rates for "plibiic order offenses,"** in particular, were reported to have been affected by fluctuations in the level of strike activity.

*Count Joseph Rybakowski's army consisted of Polish and Bohemian canal workers from Chicago, Illinois, who marched from there to Buffalo, Hew York, demanding jobs and public relief.

$\star \star V a g r a n c y$, tramps, disorderly conduct, and the like are examples of public order offenses. 
The following propositions summarize the relevant features of the conceptual and empirical work on the police and the utilization of reactive strategies in dealing with radical labor:

IX. A broadening of the scope of mobilization by labor is likely to be countered with the criminalization of segments of the surplus labor force by the police.

$x$. A high level of labor unrest is likely to be met with the criminalization of segments of the regular labor force.

The relationship between labor unrest and the use of preventive strategies appears to be quite different from the relationship between labor actions and other types of police strategies. Since a preventive strategy often involves police intervention into aspects of the lives of human beings--especially working class people--that had not previously been under the watch of the police, it is possible that there will be resentment and opposition on the part of the group or class of persons whose lives will be more closely regulated. 41 Hence, a time of labor unrest is hardly the most propitious moment to introduce preventive strategies. Rather, it is probable that:

$X I$. The lower the ievel of labor unrest, the greater the emphasis on preventive strategies.

Like collective action by the police, police mobilization may be affected by labor unrest. It is logical to assume that unrest may lead the police to accumulate more resources, to devise special plans, and to institutionalize organizational arrangements which facilitate the rapid deployment of police to the scene of labor problems . 
Harring and lfolfullin's study of the Buffalo police is one of the few sources of information on the interaction between labor's activities and police mobilization. 42 Their research highlighted the fact that the size of the Buffalo police department increased as more men and money poured into the agency to fight labor wars. They reported that "labor problems" were repeatedly cited as the reason for providing more resources to the police. Additionally, Harring and McMullin noted that there was an emphasis on a platoon system with a reserve to handle riots and labor disputes rather than on a patrol system for crime control.

To ascertain the generalizeability of findings from Harring and Mclullin's research, these two propositions need to be explored:

XII. The higher the level of labor unrest, the larger the size of the police department.

XIII. Special modifications in the organizational arrangements and practices of police departments are likely to accompany high levels of labor unrest.

Community Influence on Police Response

Community influence may be transmitted to the police through individua1s, groups, or organizations. Norms and standards, expectations about the selective enforcement of laws and pressures for changes in operating procedures, and input about the creation of laws and ordinances are a 11 components of community influence. The community influences the police either directly as in the situation of corporations paying the salaries of "special police"* or indirectly

*Special police were sworn and uniformed police with the full powers of the municipai police. They were hired, paid, and directed by private concerns. 
through the mayor's office and other units of government that are instrumental in determining police functions.

A key issue in the study of police-community relations centers on the relationship of community to other sources of influence on the police. Gutman emphasized that many historians have subscribed to the view that from the start, industrialists and big businessmen have had the social and political clout and prestige to match their economic power and that they controlled towns and police forces. 43 Stated another way, it has often been proposed that from the beginning in America, there has existed a close relationship between social status, political power, and economic class and that business interests have been able to direct police operations according to their every whim.

Two recently published studies cast doubt on the validity of this view. In one of the most comprehensive analyses of police-community relations in American Cities, Richardson identified the climate of community opinion toward a labor dispute, not economic class, as being the key factor in determining whose side the police were on. ${ }^{44}$ Gutman reached a similar conclusion in his more general inquiry on class, status, and community in industrializing America. ${ }^{45}$ He summarized his findings in the proposition that economic power was nni easily translated into social and political power in the nineteenth century.

Another important issue in police-cormunity relations involves the areas of policing that are most likely to be affected by community expectations and pressures. Wilson, in his classic study of police 
behavior, indicated that community choices tend to have a great effect on police personnel, budgets, pas levels, and organization. $46 \mathrm{He}$ strongly implied that, in general, the cormunity exercises more influence on police mobilization than on police policy regarding collective action by the police.

In another study, Wi Ison stressed that there is apt to be some conflict or difference of opinion about police operations in heterogeneous communities. 47 For example, racial or ethnic minority citizens may feel differentiy about proposals to add more police or to allow the police to use more powerful weaponry than white AngloAmerican citizens. The implication of this observation, while not entirely clear, may be that there is "strength in numbers" so far as the likelihood of minority groups influencing police functions is concerned.

Some data bearing on the subject of heterogeneous communities and influence over the police can be found in Gutman's research on Paterson, New Jersey. 48 He described the curious situation in Paterson where Benjamin Buckley, a Republican mayor, used his power over the police to suppress only violent labor disorders in the 1870s. This upset members of the economically dominant class who tried to pressure the city authorities to enlarge the police force and to limit the strikers' use of the streets and their freedom of action. But the Democratic Board of Aldermen upheld the Republican mayor on both counts. More than that, respected and powerfu? groups in the ethnically mixed Paterson community refused to support the industrialists in labor disputes. The "bottom line" in the case of 
Paterson seemed to be that the existence of vital subcultures among the immigrant and native American poor served as a source of staunch opposition to the power of the emerging upper class.

Based on the work of Wilson and Gutman, it can be expected that:

XIV. In heterogeneous communities, the presence of large numbers of economic and ethnic minorities may limit the capacity of the police to mobilize resources to use against labor.

One of the more interesting facets of the relationship between the community and police response involves the use of violent tactics by the police. Oberschall predicted that civilian casualties will be high during periods of "red scare" when public opinion favors the repression of discontented groups. 49 He impiied that more civilians are killed in these situations because social control agents know that they will not be held accountable for their actions by the community. Harring, Platt, Speiglman, and Takagi offered another explanation of police killings. According to them, political/power variables account for fluctuations in the rates of police killings. 50 To support this claim, they cited the dramatic increase in the number of civilian deaths (especially of black citizens) caused by the police between 1962 and 1969, a period of intense political struggle.

Both of these explanations have direci and clear applications to the study of the police response to labor problems. Although neither explanation is necessarily incongruent with the other one, each explanation emphasizes the importance of a certain type of 
factor in influencing police violence. The following proposition needs to be examined before any judgments can be made about the adequacy of the positions of Oberschall or Harring and his colleagues:

$X V$. The level of police violence against radical labor will be higher during periods of intense labor unrest than during periods of "Red Scare" (when public fear and hysteria about radicalism encourage repression.)*

The community's reaction to police violence is another potentially important aspect of community influence. Nilliam Gamson indicated that the best way for the authorities to maintain community support is to match their means of social control with the "trust orientation" of the opposition group. 51 He postulated that if the authorities use persuasion when dealing with groups that trusted them, sanctions and inducements with groups that were neutral, and insulation or repression with alienated groups, theri the authorities would minimize the chances of adverse community reaction. Conversely, when the authorities select means of social control that are incongruent with the status of the opposition group's trust orientation, then it becomes more costly for the authorities to deal with the opposition group because of negative community reaction. What costs are Tikely to accrue to the authorities? Ted Gurr provided some ideas on the costs of choosing incongruent means of social control. ${ }^{52}$ He maintained that inappropriate means of control,

* Labor unrest and public fear about radicalism may exist together. Hence, those interested in examining proposition 15 may need to search for periods when one of these phenomena was present and the other was not present. 
if used by the authorities, will enhance the legitimacy of discontented groups and detract from the legitimacy of the authorities in the eyes of the community. Some community groups, according to Gurr, may even respond to unnecessary police violence by assisting or joining in with the opposition group.

At least one piece of evidence seems to support the "sketchy" notions of Gamson and Gurr. From Irving Bernstein's account of the police response to the Ford Hunger March* in Dearborn, Michigan on March 7, 1932, it appears that police actions brought a result opposite to that which was planned. ${ }^{53}$ After a crowd of approximately 3,000 unemployed workingmen had peacefully paraded from downtown Detroit to the Dearborn city line, Dearborn police blocked the road and tried to stop the marchers with tear gas. Returning the fire with stones and lumps of frozen dirt, the demonstrators advanced further down the road until they reached an open field where speakers addressed the crowd. The police, licking their wounds, opened pointblack fire on the demonstrators with pistols and machine guns, killing three marchers and seriously wounding about 50 others. The Communist leaders of the March capitalized on the police "overkill" by producing a funeral extravaganza for the four martyrs. A band played the funeral dirge of the 1905 Russian Revolution, a cortege of 10,000 persons participated in a march to the cemetery, and a crowd of 30,000 gathered to hear Red orators verbally blast capitalism.

*The Ford Hunger March was a demonstration in favor of jobs, higher wages, fewer hours, and other improvements in working conditions. 
Research on the effects of the excessive use of police force on student demonstrators and others has documented similar outcomes. One study of Kent State University students' protest and sociopolitical activity before and after the "Kent State "lassacre" on ilay 4, 1970 lends support to the ideas of Gamson and Gurr. ${ }^{54}$ Utilizing self-reports of students' political activity, Raymond Adamek and Jerry Lewis collected data that indicated that exposure to extreme social control violence may have had a "radicalizing" effect on participants. In another study of the police and student demonstrators, Allen Barton found that the use of excessive force at Columbia University increased the sympathy of "third parties" (i.e., faculty and students) for the demonstrator's tactics. 55

For situations in which the police utilize incongruent means of control that are overly coercive, the net effect probably is to make the police task of controlling labor unrest more difficult. The next proposition, however, deals with an "intermediate" phase in the interactive process which links excessive police violence to the aggravation of police problems in dealing with labor.

$X V I$. The use of excessive force is likely to radicalize third parties to the class struggle between the capitalist and working classes.

But what if the community never learns about the police use of incongruent means of control or is misinformed about how social control is carried out? This is where the communications media come into the making of police response. Michael Lipsky has emphasized that the media are an extremely powerful community institution that affect the authorities' actions. ${ }^{56}$ The media grant or withhold publicity on 
police activities, select the information that most of the community will have on police-related issues, and decide what alternatives the community will consider in response to civic affairs.

What determines the ideas, issues, and choices that are presented by the media? From a strict Marxian viewpoint, it might be held that newspaper editors and other media representatives produce news that augments their own material interests. This is a somewhat vulgar and overly-deterministic stance. Harvey Molotch has developed a plainer conceptualization of the class bias of the media. 57 His basic position is that there are several reasons why the mass media in the United States have been under the control of the capitalist class. First, the owners of the newspapers and the television and radio stations are themselves either members of the capitalist class or aspire to such membership. Second, the revenues of the media are heavily dependent upon advertisements and grants from the capitalist class. Third, the capitalist class is the single most important social influence on the national government which, through its regulatory agencies and through the courts, controls the media. Fourth, the capitalist class is the most important force in structuring the national ideology through mechanisms such as education, voluntary associations, religious organizations, theatre, etc.--the other media that socialize news producers and news consumers .

In addition to material interests, community responses to media content must be examined if a full account of the relationship is to be given of the impact of the media on the police. While a 
newspaper may share the capitalist class's belief in the "free enterprise system," this belief may not become articulated in print. Then too, community members may not respond to a news article or an editorial in the manner desired by the editor. In short, the community or parts of it may resist manipulation by the media. Donald Sofchalk's analysis of the interplay between the police, the press, and the community following the Chicago Memorial Day Incident* is instructive in the regard of media influence. ${ }^{58}$ Prior to the Incident, public opinion favored labor. Yet, the public's reaction to the Incident was to hold the strikers and their C.I.0. leaders responsible for the violence that occurred. Sofchalk attributed this shift in community attitudes to the news media's unbalanced accounts of the event. The picture painted by the Chicago Daily Tribune and other local papers represented only the police version of what happened. Headlines such as "Riots Blamed on Red Chiefs" served to concentrate public attention on "outside" agitators and other "radicals" who had allegedly planned the entire affair. When one places the media's biased performance in historical perspective, the "power of the press" appears somewhat staggering. If Sofchaik's analys is is correct, then the decade's most spectacular, single occurrence of industrial war failed to provoke any support for labor, in part, because of the fallacious and misleading content of the Chicago newspapers!

*The Chicago Memorial Day Incident involved a clash between 1,500 workers on strike from the Little Steel plant and 300 members of the Chicago Police Department on Memorial Day, 1937. When several stones were thrown at the police, they responded by shooting 6 persons dead and by brutally attacking the workers with enough force to wound 58 persons. 
Another example of the ability of the press to shape public opinion is the encouragement offered for acts of police violence against tramps by the papers in Buffalo, New York in the 1890s.59 The Buffalo media were at least partially responsible for the public clamor for strengthened and more repressive anti-tramp measures. Still another case in point is the propaganda contest waged between the established newspapers and the Arbeiter Zeitung, an Anarchist paper, in Chicago in the 1880s. While the larger newspapers damned the A.F.L.'s campaign to win the eight hour day as "communism, lurid and rampant, "60 the Anarchist media fanned the flames of worker unrest and denounced the police for shooting strikers. ${ }^{61}$ In the end, the major press seems to have been more successful since pubtic sentiment was polarized against the Anarchists after the Haymarket Riot.*

The main themes of the above analysis of the media and police response can be expressed as a set of propositions.

XVII. The more the media is dependent upon the capitalist class, the more likely that the media content will be supportive of police policies, strategies, and tactics that benefit the capitalist class.

XVIII. The more biased the media content in favor of the capitalist class, the more supportive the community is likely to be of police policies, strategies, and tactics that benefit the capitalist class.

*The Haymarket Riot took place May 4, 1886 in Haymarket Square in Chicago. Police killings outnumbered citizen killings of police about two or three to one, after a bomb was thrown at the police. 
XIX. The more strongly the cormunity supports a police response that serves the interests of the capitalist class, the more likely that such a response will be implemented.

\section{The Factor of the Police in Police Response}

Besides class interests, state interests, and community influences, the police themselves shape police response. Role conflicts, police organizational characteristics, and police attitudes all affect police behavior. Generally, these aspects of police response have been dealt with separately by students of the police; there have been few attempts to develop a conceptual framework that links psychological and organizational variables to broader social structural bases of action.*

ilarxian social theory, with its emphasis on structural environments, allows for the incorporation of empirical data from some of the benchmark studies of Wilson, Skolnick, and others, while it directs attention to social class as a determinant of police response. With regard to role conflict and police response, the interface of class and occupation as sources of identity for police officers seems to be a useful but overlooked area of inquiry. A central contradiction of police work is that even though the police have been recruited from the working class, they have been saddled with the task of policing the working class. It is reasonable to expect

*One of the few attempts to develop such an analytical framework was made by $C$ layton $A$. Hartjen. Hartjen abstracted findings from criminological research on the police and reinterpreted them from a perspective of social order and interpersonal interaction. See Clayton A. Hartjen, "Police-Citizen Encounters," Criminology, 10, 1 (May, 1972), pp. 61-84. 
that when an officer, who views himself as being a "worker" as well as a police "professional" intervenes into a labor dispute, he/she may make certain compromises, accommodations, or even concessions to organized labor.

From the point of view of police administrators and other city authorities, it may be necessary to thwart these tendencies by building the officer's commitment to the police occupation. How can occupational commitment be increased for those working in police organizations? Harring found that high salaries, military discipline, and an emphasis on neutrality were used to encourage loyalty among rank and file police officers in Buffalo, New York during the labor strife of the late 1800 s. ${ }^{62}$

In order to guage when commitment mechanisms such as those identified by Harring and McMullin are likely to be stressed in police departments, it is useful to explore the applications of the concepts of "alienation" and "dual power structure." In regard to these concepts, it can be postulated that a person is most apt to change role affiliations after he or she becomes alienated or withdraws from an established social system and after he or she becomes aware of the existence of a competing system that has about the same amount of power (i.e., a dual power structure). The implication for police mobilization is that commitment to the police occupation may be in jeopardy when the police become alienated from their work and when labor organizations accumulate sufficient power to compete for their loyalties. 
The following relationship is predicted betiveen the amount of power possessed by labor and police mobilization:

$X X$. In situations where radical labor has amassed a considerable amount of power, there is likely to be an emphasis on "commitment mechanisms" (e.g., salaries, discipline, neutrality ethic, etc.) in police departments.

In terms of organizational characteristics, professionalization should make a difference in police response. There are two contrasting positions on the effects of professionalization on response. Oberschall suggested that a professional police department is less likely to engage in unnecessary violence than is a non-professional one. ${ }^{63}$ He reasoned that if a department has clearly spelled-out guidelines for the use of force and its leadership exercises control over rank and file officers, then the department will be more accountable. A high degree of accountability, in turn, should reduce the level of police violence, according to Oberschall.

The Center for Research on Criminal Justice assumed a different posture. ${ }^{64}$ It contended that the introduction of police reforms such as professionalism has not diminished the importance of the "iron fist" side of the police function. Instead they viewed professionalism as being the "velvet glove" side of policing, the side that serves to obscure and to legitimize the violent, coercive aspects of the other side of the police role. In sum, the Center's position is that a professionalized police force is not less violent than an unprofessionalized one.

The relationship between professionalization and violence is probably more complex than either position indicates. Perhaps the 
most critical issue has been all but ignored. That issue revolves around the notion of the "locus of control" over the police.* It is logical to think that the nature of police response depends, to some degree, on whether control is "internal" or "external." In fact, the writings of several police experts suggest that police violence can only be reduced when the police are controlled by forces outside of police organizations. Skolnick, for one, criticized the idea that the answer to the problem of accountability lies in the improvement of internal police administration. ${ }^{65}$ Instead of internal control over the police, Skolnick opted for external control in the form of the "rule of Iaw."** In a similar manner, Walker argued that external means of control (e.g., community control and civilian review boards) promote public accountability. ${ }^{66}$

If we accept the line of reasoning advanced by Skolnick and Walker, the key question becomes, "how is police professionalism related to the institutionalization of external mechanisms for controlling police behavior in police departments?" Judging from the historical development of police professionalism, it does not appear that the professionalization has been accompanied by the introduction of external means of control. To the contrary, controls over the police have developed largely within the structure of police departments. 67 This should not be surprising given the "managerial"

*0berschall made a passing reference to this issue. See Anthony Oberschall, Social Confilict and Social Movements (Englewood Cliffs, N.J.: Prentice-Ha71, Inc., 1973), p. 338.

**The term "rule of law," as used by Skolnick, refers to the rights of individual citizens and the legal constraints upon the police. See Jerome H. Skolnick, Justice Without Trial (New York: John Wiley and Sons, Inc., 1967), p. 6. 
conception of professionalism that was promoted in the eariy battles against police corruption. To translate this managerial view of professionalism into actual police practices, efficiency-minded "professionalizers" attempted to enhance the power of police executives, to install centralized rational administrative procedures, and to improve the quality of the police officer. ${ }^{68}$

One of the costs of developing a professional code based upon a model of administrative efficiency has been the increasing insulation of the police from the community. Whereas the centralization of power and authority and the use of impersonal management techniques may have improved the efficiency of police departments, these same features have tended to cut the police off from the influence of the working class and the labor movement. ${ }^{69}$ On a more general level, it appears that the professionalization of the police may have so undermined the capacity of the police to be accountable to external controls that in the year 1979 it has become exceedingly difficult to provide a solid answer to the question, "who controls the police?"*

Returning to the matter of the relationship between police professionalism and the level of police violence, a proposition specifying the type of control seems to be in order.

*The police are not unique in terms of being relatively immune from external regulation. Magali Larson's account of the process by which professions emerge illuminates the fact that al1 professions seek autonomy; this autonomy tends to insulate them from the public and from political authorities. See Magali Larson, The Rise of Professionalism: A Sociological Analysis, (Berkeley, Calif.: University of California Press, 1977). 
XXI. No marked differences are expected in the leve 1 of police violence against radical labor between professionalized police departments in which only internal controls are present and non-professionalized police departments .

A final factor that shapes the police response in human volition. The attitudes, values, and experiences of individual officers are important in determining how the police react to strikes, parades, and other contentious gatherings sponsored by organized labor.

How does one go about studying the role of individual police officers in labor wars? To study the human factor in any kind of situation, Frederick Teggart, the noted philosopher of history, stressed that mental and physical activity are, in large part, due to the occupational, social, and geographical surroundings in which one finds himself or herself. 70 Skolnick's investigation of how the occupational environment of policing molds a set of cognitive tendencies among police exemplifies the approach suggested by Teggart. ${ }^{71}$ One of Skolnick's main contentions was that police officers become very supportive of the status quo by virtue of enforcing the law. He argued that to believe in their task and to appear consistent to themselves, police become extremely conservative. For some officers who rigidly adhere to conservative ideas, it may be necessary to view the proponents of opposing ideological positions such as radicals as being "dangerous, immoral devils." Walter "Miller labeled this as constituting a mental state of "fdeological intensification." 72 
In a similar way, the police occupation seems to foster antilabor attitudes among patrol officers. In fact, Skolnick maintained that handling labor disputes is one of the best examples of situations inclining the police to support the status quo. ${ }^{73}$ In these situations, the responsibilities of their job lead the police to see striking, picketing, militant workers as disturbing the order that they are charged with maintaining. Some rare bits of information on the antilabor bias of police have been recorded by Harold Ickes, who was an attorney in Chicago for part of his career. Here is how he described the handling of clashes between employers and workers between 1886 and the 1930s by the Chicago Police.

The Augean stables emanated delicate perfume compared with some of the odors that have been redolent in this Department in the past. From the time of the Haymarket Riots (1886) in Chicago, police always justified the brutal invasion of civil rights by calling those whom it manhandled "anarchists." 74

Besides the studies on the anti-radical and anti-labor attitudes of police, other research has documented the ethnic and racial prejudice of some officers.* Interview data collected by the "LaFollette Committee," 1930s regarded participants in picket. lines and C.I.0. demonstrators as being either "misguided" foreigners or Communists. 75

*For an overview of the literature on racial attitudes in police departments, see Don C. Gibbons, Society, Crime, and Criminal Careers, 3rd. ed. (Englewood Cliffs, N.J.: Prentice-Hall, Inc., 1977), pp. 75-76.

**The LaFollette Committee was a subcomittee set up by the Senate Committee on Education and Labor to counteract illegal interference with worker's civil rights through espionage, provocation, and organized violence. The subcomittee was chaired by Senator Robert M. LaFollette, Jr. of Wisconsin. 
How do police attitudes relate to police response? They are related in that the police may overreact in handling events of collective action, if they hold erroneous views about the workers, radicals, or ethnic group members who are participating in the action. 76 Furthermore, police behavior may become particularly overzealous and unwarranted if the targets of police reaction possess the combined characteristics of ethnicity, union membership, and radical politics.

The police activities in Weirton, West Virginia on 0ctober 7 , 1919 offer an illustrative example of what can happen when there is a confluence of these factors. Weirton police rounded up 150 Finnish Americans, marched them to the public square, and forced them to kneel and kiss the United States' flag; then, the police drove them out of town. Police authorities justified their actions by pointing out that the 150 persons were the chief agitators in a steel strike and were suspected of being members of a radical group in Finland. ${ }^{77}$

The type of overreaction exhibited by the Weirton police would definitely classify as the use of "incongruent means of social control." It seems that attitudes may be an important factor in determining inappropriate and seemingly irrational responses by the police. Based on the above-described ideas about police attitudes and on Gamson's conceptualization of incongruent means, it is anticipated that:

XXII. Police who possess erroneous and extreriely biased attitudes against an ethnic group, a labor organization, and/or a particular political ideology are more prone to utilize incongruent and excessively violent tactics than police who do not possess such attitudes. 
Conclusion

This framework may be considered to represent one theoretical orientation to the study of the police response to labor radicalism. In the course of developing the framework there has been an attempt to avoid some of the pitfalls of "vulgar" Marxism. The state has been viewed as the terrain on which struggles between classes and groups are fought, rather than as the always faithful servant of the capitalist class.* Then too, there has been a recognition of the ways in which the community as well as the police themselves may affect police response. As a whole, the framelwork is intended to be a more encompassing and nuanced view of the police role in class conflict involving labor radicals than has been constructed heretofore.

*David Greenberg criticized Richard Quinney, the Mlarxian criminologist, for failing to appreciate the fact that stateorganized crime control policies may be adopted in response to pressure from classes other than the capitalist class. See Greenberg's review of Quinney's Class, State, and Crime in Crime and Delinquency, 25, 1 (January, 1979), pp. 110-173. 
1. Charles Tilly, From Mobilization to Revolution (Reading, Mass.: Addison-Wesley Publishing Company, 1978), pp. 69-71.

2. Tilly, op. cit., p. 107.

3. Ibid., p. 100.

4. Peter K. Manning and John Van Maanen, "Strategies of Policing," in Manning and Van Maanen (eds.), Policing: A View From the Street (Santa Monica, Calif.: Goodyear Pubtishing Company, Inc., 1978), pp. 141-146.

5. Albert J. Reiss, The Police and the Public (New Haven, Conn.: Yale University Press, 197/).

6. Staughton Lynd (ed.), American Labor Radicalism (New York: John Wiley and Sons, Inc., 1973), p. 4.

7. James Q. Wilson, Varieties of Police Behavior (Cambridge, Mass.: Harvard University Press, 1968).

8. Roberta Ash Garner, Social Change (Chicago: Rand McNally College Publishing Company, 1977), p. 252.

9. E. P. Thompson, The Making of the English Working Class (New York: Vintage Books, 1966), p. 9.

10. Philip Taft and Philip Ross, "American Labor Violence: Its Causes, Character, and Outcome," in Hugh D. Graham and Ted R. Gurr, The History of Violence in America (New York: Bantam Books, 1969), pp. 381-382.

11. Melvyn Dubofsky, We Sha11 Be A11: A History of the Iiw (New York: Quadrangte, 1969).

12. Ibid., p. 277.

13. Wyndham Mortimer, Organize! My Life as a Union Man (Boston: Beacon, 1971).

14. Ibid., p. 129.

15. G. William Domhoff, Who Rules America? (Englewood Cliffs, II.J.: Prentice-Hal7, Inc., 1976).

16. Sidney L. Harring and Lorraine M. McMullin, "The Buffalo Police 1872-1900: Labor Unrest, Political Power and the Creation of the Police Institution," Crime and Social Justice, 4 (Fall-Winter, 
17. Don C. Gibbons, "Radical Criminology Revisited: Social Interests, Social Change, and the Criminal Justice System," Paper Presented at the Pacific Sociological Association Meetings (Spokane, 1978), p. 11 .

18. Herbert Gutman, "The Tompkins Square 'Riot' in New York City on January 13, 1874: A Re-examination of its Causes and its Aftermath," Labor History, 6 (Winter, 1965), pp.

19. Garner, op. cit., p. 255.

20. Roger Lane, Policing the City: Boston, 1822-1885 (New York: Atheneum, 1975).

21. James Weinstein, The Decline of Socialism in America, 19121925 (New York: Monthly Review Press, 1967), pp. 93-103.

22. Sally M. Miller, "Milwaukee: Of Ethnicity and Labor," in Bruce 11. Stave (ed.), Socialism and the Cities (Port Washington, N.Y.: Kennikat Press, 1975), pp. 41-71.

23. Herbert Gutman, Work, Culture, and Society in Industrializing America (New York: Vintage Books, 1976), pp. 234-260.

24. Harring and licMullin, op. cit., p. 7.

25. Cyril D. Robinson, "The Mayor and the Police--The Political Role of the Police in Society," in George L. Plosse (ed.), Police Forces in History (Beverly Hills, Calif.: Sage Publications, 1975), pp. 277-315.

26. James F. Richardson, Urban Police in the United States (Port Washington, N.Y.: Kennikat Press, 1974), pp. 158-187.

27. Karl Marx, A Contribution to the Critique of Political Economy (Chicago: Charles H. Kerr and Company, 1904), p. 182.

28. Andrew Hopkins, "On the Sociology of Criminal Law," Social Problems, 22 (5: 1975), pp. 608-619.

29. Ibid.

30. Tilly, op. cit., p. 111.

31. Claude E. Hoffman, Sit-Down in Anderson: UAll Local 663, Anderson, Indiana (Detroit: Wayne State Universit $y^{\prime}$ Press, 1968), pp. 47-55.

32. Gutman, "The Tompkins Square Riot," op. cit.

33. Tilly, op. cit., p. 190. 
34. Donald J. Black, "The Mobilization of Law," in Peter K. Manning and John Van Maanen (eds.), Policing: A View From the Street (Santa Monica, Calif.: Goodyear Publishing Company, Inc., 1978), pp. 167-187.

35. Ibid., p. 181.

36. Hoffman, op. cit., p. 57.

37. Gutman, op. cit.

38. Clayton A. Hartjen, Crime and Criminalization (New York:

Praeger Publishers, 1974), p.

39. Sidney Harring, "Class Conflict and the Suppression of Tramps in Buffa 10, 1892-1894," Law and Society Review, 11, 5 (Summer, 1977), pp. 873-911.

40. Harring and McMullin, op. cit., p. 12.

41. Anthony Oberschal1, Social Conflict and Social Movements (Englewood Cliffs, N.J.: Prentice-Ha11, Inc., 1973), p. 249.

42. Harring and Mclluliin, op. cit., pp. 7-9.

43. Gutman, Work, Culture, and Society, op. cit., p. 236.

44. Richardson, op. cit., p. 159.

45. Gutman, Work, Culture, and Society, op. cit., p. 258.

46. James Q. Wilson, Varieties of Police Behavior (Cambridge; Mass.: Harvard University Press, 1968), p. 227.

47. James Q. Wilson. "The Police and Their Problems: A Theory," in Public Policy, A Yearbook of the Graduate School of Public Administration (Cambridge, Mass.: Harvard University, 1963), pp. 198-799.

48. Gutman, Work, Culture, and Society, op. cit., pp. 242-246.

49. Anthony Oberscha11, "Group Violence," La'w and Society Review, 5, 1 (August, 1970), p. 75.

50. Sidney Harring, Tony Platt, Richard Speiglman, and Paul Takagi, "The "lanagement of Police Killings," Crime and Social Justice, 6 (Fall-Winter, 1977), p. 34.

51. William A. Gamson, Power and Discontent (Homewood, I11.: Dorsey Press, 1968), pp. T11-143. 
52. Ted R. Gurr, Why Hen Rebel (Princeton, N.J.: Princeton University Press, 1970), pp. 347-359.

53. Irving Bernstein, The Lean Years: A History of the American Worker, 1920-1933 (Baltimore: Penguin Books, 1970), pp. 432-434.

54. Raymond J. Adamek and Jerry $M$. Lewis, "Social Control Violence and Radicalization: Behavioral Data," Social Problems, 22 (5: 1975), pp. 663-674.

55. Allen H. Barton, "The Columbia Crisis: Campus, Vietnam, and the Ghetto," Public Opinion Quarterly, 32 (Fal1, 1968), pp. 333351 .

56. Michael Lipsky, "Protest as a Political Resource," American Political Science Review, 62 (December, 1968), pp. 1144-1158.

57. Harvey Molotch, "Media and Movements," in John McCarthy and Mayer Zald (eds), Social Movements and Resource Mobilization (Beverly Hills: Sage Publications, 1979),

58. Donald G. Sofchalk, "The Chicago Memorial Day Incident: An Episode of Mass Action," Labor History, 6 (1: 1965), pp. 3-43.

59. Harring, "Class Conflict and the Suppression of Tramps," op. cit., pp. 890-892.

60. Sidney Lens, Radicalism in America (New York: Thomas Y. Crowell Company, 1969), p. 167.

61. William E. Trible, "Haymarket Riot: May 4, 1886," FBI Law Enforcement Bulletin, 47, 5 (Mlay, 1978), p. 17.

62.- Harring, "Class Conflict and the Suppression of Tramps," op. cit., p. 888.

63. Oberschal1, Social Conflict and Social ilovements, op. cit., p. 338.

64. Center for Research on Criminal Justice, The Iron Fist and the Velvet Glove, Second Edition (San Francisco: Garrett Press, 7977), pp. 39-42.

65. Jerome Skolnick, Justice Without Trial (New York: John Wiley and Sons, Inc., 1966), p. 5.

66. Samuel Walker, "Police Professionalism: Another Look at the Issues," Journal of Sociology and Social Welfare, III (July, 1976), pp. 707-710.

67. Susan White, "A Perspective on Police Professionalization," Law and Society Review, 7, 1 (Fal1, 1972), p. 66. 
68. Samuel Walker, A Critical History of Police Reform (Lexington, Mass.: Lexington Books, 1977), pp. 53-106.

69. Ibid., p. 76 .

70. Frederick J. Teggart, Theory and Processes of History (Berkeley, Calif.: University of California Press, T977), pp. 268-292.

71. Skolnick, op. cit.

72. Walter B. Miller, "Ideology and Criminal Justice Policy: Some Current Issues," The Journal of Criminal Law and Criminology, 64 (June, T973), pp. T4T-162.

73. Skolnick, op. cit., p. 59.

74. Harold Ickes cited in Richardson, op. cit., p. 160.

75. Sofchalk, op. cit., p. 18.

76. Oberscha11, Social Conflict and Social Hovements, op. cit., p. 306.

77. Carl Ross, The Finn Factor in American Labor, Culture, and Society (New York MiTTs, N.Y.: Parta Printers, Inc., 1977), pp. 157-158. 
THEY SHOOT WOBBLIES, DON'T THEY? 
CHAPTER III

THE SEATTLE AND PORTLAND POLICE AND

THE LABOR RADICALS, 1912-1920

The Research Problem

Nobody appears to know why the average officer can't keep his temper in dealing with crowds, but he can't. There was no need to club anybody; there was no need to curse anybody; there was no need to shout and rave and kick and pull and yank, for that crowd was willing to do what the officers ordered it to do, but the officers went wild, as they have done before... 1

This excerpt from a newspaper editorial on the subject of a police attack upon free-speech fighters in Portland on October 29, 1913 is indicative of the disquietude of laypersons and academicians alike over the apparent irrationality and inexplicability of police behavior in encounters with radicals. Some scholars have even suggested that police violence is both arbitrary and personalized. ${ }^{2}$

Another point of view on police encounters with labor radicals has been explicated in the theoretical framework of this dissertation. A central contention of this perspective is that the urban police function is best understood in terms of political and economic interests, power relations, and class conflict. Then, too, it is assumed that police actions are, to a large extent, structured by the political nature of the police institution as it exists within municipal government and by the class position of the police as workers. Implicit in this perspective on police behavior is the 
idea that seemingly irrational police actions are in fact, rational responses to the police-community situation.

The purpose of the present inquiry was to explore and to analyze the phenomenon of the police response to labor radicalism in Portland, Oregon and Seattle, Washington during the period of 1912-1920. Although it was assumed that political, economic, and social factors shaped the ways in which the police in these two cities dealt with members of the Industrial Norkers of the World (I.W.W.) and other labor radicals, the question of whether or not this was the case with regard to the actions of the Seattle and Portland police in the early twentieth century is an empirical issue. It is hoped that some light can be shed on this issue by searching for the social forces that influenced the police response to labor radicalism from 1912-1920 (the period which included highest levels of class conflict involving the I.W.W. in Seattle and Portland).

In addition, this investigation involved an attempt to identify details pertaining to the police response to radical labor unrest that are generalizable to the police activities in other cities and in different periods of history. At the same time, it should be recognized that portions of this study can only be understoo's in relation to the particular events occurring in the world, in the United States, and in Portland and Seattle during a specific period in history.

The main objectives of this part of the dissertation were as follows: 
1. Describe the police response to labor radicalism in Portland and Seattle from 1912-1920.

2. Identify the changes and continuities in the police response to labor radicalism within the Portland and Seattle city police departments.

3. Ascertain the similarities and differences in the police response between the Portland and Seattle city police departments.

4. Explain the variations in police response both within and between the Portland and Seattle city police departments in terms of particular social forces.

The Methodological Approach

To realize these objectives, the following data sources were utilized: 1) archival data (e.g., annual reports of Portland and Seattle police departments, mayor's correspondence, police payroll records, city auditor's reports, city council papers, manuals of standard operating procedures of police departments, and notebooks of police detectives), 2) personal documents (e.g., manuscript collections of former members of the Portland and Seattle police department, I.W.W. organizers, former mayors, former police chiefs, and I.W.W. lawyers), and 3) public documents (e.g., Portland and Seattle daily newspapers, union newspapers, histories of the cities of Portland and Seattle, histories of the police departments of Portland and Seattle, and taped interviews with former police officers).

The selection and operationalization of the specific variables on which data were collected was based on the propositions identified in the conceptual framework. These include variables that relate to the following areas: a) linkages between class power, state power, 
and police response, b) patterns of labor discontent and police response, c) community influence on police response, and d) the factor of police organization in police response.

Whenever it was possible, primary sources of data were used. However, reliance often had to be placed upon secondary sources because of the lack of primary sources in some parts of the inquiry. Extensive use of secondary sources was made in studying the police response in Seattle since many valuable police records were destroyed several years ago.

A variety of techniques was used to collect data from the above-mentioned sources. First, a document schedule was used for recording data obtained from Portland and Seattle daily newspapers. Appendix A contains a copy of the document schedule. Second, several focused interviews of former police officers were conducted. During these interviews, former police officers were asked a series of general, open-ended questions that focused attention upon their handling of labor disputes involving the I.W.W. Questions were derived from the conceptual framework and combined into the form of an interview guide. Appendix B contains a copy of the interview guide.

Besides these data collection techniques, there was a considerable amount of general information gathering. Arrest data, for example, was gleaned from the annual reports of the Portland and Seattle police agencies. Information from daily newspapers was a most important source of data. Additionally, there was a certain amount of pouring over old manuscripts left by the police, city 
authorities, and members of the I.W.W. in an attempt to ferret out personal interpretations of clashes between the police and the I.W.W.* Turning to the matter of data analysis, data from personal documents, and public documents were analyzed qualitatively.** The management and organization of these non-quantified data was accomplished through the use of some basic historiographic techniques. Lengthy passages copied from published and non-published materials, chronologies of key events, and sketches and diagrams of relationships tentatively posed between variables were all utilized. In

* With regard to the use of the above-discussed sources and techniques, several methodological concerns need to be addressed. As in all historical research, a major problem in this study lies in the inaccuracy and bias of some of the documents. Typically, the reports of local government agencies such as police organizations are biased in favor of the authorities. 3 To deal with this problem, alleged facts in government sources were cross-checked with other primary sources authored by I.W.W. members or with secondary sources such as newspapers that are somewhat more neutral than the I.W.W. However, another problematic area involves the extreme bias of some newspapers. The Portland Oregonian, for instance, has historically slanted its news toward the view of business interests in the community. Information from newspapers was validated by cross-references to primary sources when they were available and to other newspapers if primary sources were lacking.

There were also limitations on the availability of subjects for interviews. Almost all of the prospective interviewees could not be interviewed due to a variety of reasons, including death, failing health, recent changes of residence to other regions of the country, and personal feelings of shame. With respect to the last reason, two former members of the Seattle Police Department declined an offer to be interviewed, stating that they were "too ashamed of what they had done to the Wobblies to go through an interview." Thinking that these refusals may have been due to the author's own status "outside" of police circles, two active members of the Portland Police Bureau were trained as interviewers and sent into the field. They also were turned down by the same two former Seattle police officers as well as several other ex members of the Seattle Police Department. The interviewers from "inside" the police occupation, however, did manage to complete two interviews with former Seattie police officers.

**The use of quantitative forms of analys is was precluded due to limitations in the scale and the amount of data that was available for this research. 
analyzing all of this information there also was an emphasis upon examining data along a temporal dimension. When data from different time periods were available, within and between departmental comparisons were made in order to detect changes in relationships that occurred over time.

\section{The Setting for Police-Radical Labor Interaction}

This investigation of the encounters between the police and the labor radicals in Portland and Seattle focused on one constant and one variable. The constant is the fact that 1 abor radicalism posed a significant challenge to the leaders of American corporate capitalism from the early 1900s down through World War I. One of the main organizational vehicles for the expression of this radicalism was the I.W.W. With its preamble proclaiming that the working and employing classes have nothing in common, the I.H.W. seemed to many employers of this time to be an incarnation of Marxian prophecy. ${ }^{4}$ From the woolen mills of Lawrence, Massachusetts to the iron ore mines of the Mesabi Range in Minnesota to the wheatfields, shipyards, sawmil1s, and forests of the Pacific Northwest, the Wobblies presented a militant threat to the basic fabric of American society.

Throughout the entire period of 1912-1920 the specter of the I.W.W. loomed large in the cities of Portland and Seattle. Not only were these cities the sites of I.W.W. action, additionally both were centers of anti-union activities directed at the I.W.W. and other radical organizations which aided the cause of militant working men 
and women. Mill owners, logging entrepreneurs, shipping company magnates, and similar types of employers played a key role in planning and organizing activities to suppress the labor radicals. The reason for the opposition of these employers to the I.W.W. Was a contradiction of interests. Whereas the I.W.W., with its' advocacy of worker control and revolutionary union tactics, challenged the existing distribution of wealth and power in society, these employers, with their monopoly control over the extractive industries upon which the economies of Portland and Seattle were dependent, were part of the most privileged group in the Pacific Northwest. In short, the interests of these two groups predisposed them to be antithetically opposed to one another.

Additional to the actions of the employers and the labor radicals, the course of the conflict between these groups appears to have been affected by the sometimes shifting allegiances of "third parties" that were mainly based in Seattle and Portland. The media was one of these parties. The content of Seattle's major newspapers, namely the Seattle Times and the Seattle Post-Intelligencer, and Portland's largest newspapers, the Portland Oregonian and the Oregon Journal, were extremely biased in favor of business interests throughout the period of 1912-1920. The biases of the Seattle Star and the Portland News, two Scripps * owned newspapers, seemed to change during this period. Both papers were pro-labor prior to World War I, but they shifted to an anti-labor position during the

*E. W. Scripps was the owner of both the Star and the News. 
war. ${ }^{5}$ Labor's main supporters among the media were the Seattle UnionRecord, the first labor-owned daily newspaper in the U.S., and the Industrial Worker, the I.W.W. newspaper. Both of these papers remained loyal to the labor radicals from 1912 through 1920. Members of the Socialist Party* and the Socialist Labor Party** joined the Wobblies in skirmishes with employers and city authorities in 1912 and 1913 and in some major confrontations with the dominant economic and political interests in 1917 and 1919. :Aembers of local unions affiliated with the American Federation of Labor (A.F.L.), ${ }^{\star \star \star}$ the I.W.W.'s strongest competitor in terms of labor organizing, also aligned with the I.W.W. several times between 1917 and 1919 in what amounted to class war between the working class and the economically dominant class. For tite greater part of the period of 1912-1920, however, the A.F.L. assisted in the efforts to crush the I.W.W. Finally, members of the Communist Party**** and

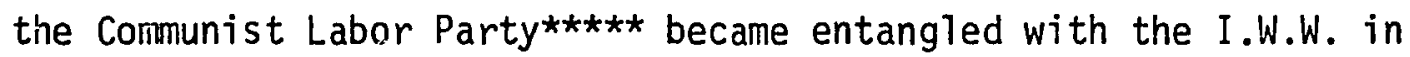

*The Sociaijst rarty is a political party that was formed in 1901. The Party's basic strategy has been to work for "immediate demands" or realizeable reforms, while its ultimate goal has been to create a socialist society.

**The Socialist Labor Party was a political party organized in 1874. The Party took the position that reforms should not be sought within the context of the capitalist system, but only as part of a socialist revolution. For a more complete delineation of the ideology and goals of the socialist Labor Party, see Sidney Lens, Radicalism in America (New York: Thomas Y. Croweil Company, 1969).

$\star \star \star T$ The American Federation of Labor is a national labor organization that was founded in 1886. The A.F.L. organized workers on the basis of crafts in the early 1900s.

$\star \star \star \star T$ The Communist Party was organized in the U.S. in 1919. It was composed primarily of foreign-born persons who belonged to Communist foreign language federations in the 1920s.

$\star \star \star \star \star *$ The Communist Labor Party was also organized in 1919. Initially it was made up mainly of American intellectuals. 
Seattle and Portland in 1919-1920 when the repression of radicals was extraordinarily severe.

With regard to the demographic characteristics of the two cities, it does not appear that these types of factors were likely to have had much of an effect upon the police role in the class struggle in Portland and Seattle from 1912-1920. The size of the populations in both cities, for example, was roughly the same in 1912 (i.e., over 200,000 inhabitants in each city) and in 1920 (i.e., over 250,000 inhabitants in each city). ${ }^{6}$ It is conceivable, however, that a study more specifically focused on the impact of physical characteristics on police-labor radical relations might uncover evidence on the ways in which demographic factors affected police actions in regard to labor radicals.

As for the variable or varying force analyzed in this study, it is proposed that the actions of the Seattle and Portland police vis a vis the Wobblies and other labor radicals changed in response to shifts in social forces that were themselves in motion. Police mobilization and collective action in both cities was inextricably bound to the origins, organization, size and previous history of handling labor unrest of the Seattle and Portland police departments.

In terms of the origins of the police in Seait: and Portiand, the police forces in these cities assisted in the process whereby the vast natural resources of the Pacific Northwest were transformed into capital. 7 Then too, the first modern police department in each city was established, in part, as response to the need to protect private property from being destroyed by the riots of the 
1870s. ${ }^{8}$ Given these origins, it appears that the Seattle and Portland police mainly functioned as the defenders of economic interests in their earliest years of existence.

Since the time of the official formation of police departments in Seattle and Portland, the organization and function of the police in these cities has been influenced by political as well as economic interests. Local political control has been a predominant force in the history of both police departments. In particular, the Seattle City Council exercised authority over the police for the entire period of 1912-1920. The Portland City Council formally controlled the police in that city in 1912 and a Commissioner of Public Safety (i.e., the Mayor under the commission form of municipal government) directed the police in Portland from 1913 through 1920. State control over the Seattle and Portland police departments existed in the form of the power of the Washington and Oregon state legislatures to enact criminal laws which the police were responsible for enforcing throughout the period of 1912-1920. Even some degree of national political control over these police departments was present during World War I.

With regard to the city police departments per se, the seattle and Portland police departments featured two major branches and several special units during the years under consideration. ${ }^{9}$ Most of the police in both departments were part of patrol divisions. These officers wore uniforms and were assigned beats to patrol. Other police officers worked in detective divisions. :lany of these officers wore plain clothes and conducted criminal investigations. 
In addition to the departments' major organizational components, each department had specialized units. The existence and operations of these units largely seems to have depended upon prevailing social conditions. Red squads, for instance, emerged within the Portland and Seattle police departments when radicalism became an important problem for the economically dominant class and for the larger society.

Size was a point of dissimilarity between the two departments. In 1912 the Portland Police Department had a total of 292 sworn officers, while the Seattle Police Department had a total of 329 officers. 10 By 1920 the total strength of the both departments was approximately 400 police officers. ${ }^{11}$ Besides the regular police force, both cities utilized auxiliary police forces at different points in time between 1912 and 1920. These auxiliary police were often referred to as "special" police because they were hired for riots, major strikes, and other special situations.

With respect to the handling of labor unrest by the Seattle and Portland city police prior to 1912, the available information pertains to police involvement in a few, possibly unrepresentative events. In part, this lack of information has stemmed from the low level of organized labor activity that existed before the I.W.W. had firmly established itself in Seattle and Portland.

The anti-Chinese incidents of 1884-1886 are perhaps the most frequently cited of the early police encounters with militant workers in Seattle. ${ }^{12}$ The Seattle police "distinguished" themseives in one of these incidents when they refused to break up a mob of native-born 
laboring men who attempted to forcibly deport a large group of Chinese to San Francisco. ${ }^{13}$ Since the police did not intervene into this disturbance, it has been alleged that they were in sympathy with the mob. 14

One of the most famous of early police contacts with labor radicals in Portland was the 1907 I.N.W. sawmill strike. The relatively controlled behavior of the Portland police was evidenced by the absence of any police-initiated violence and by the fact that there was only one strike-related arrest during the 40-day strike. ${ }^{15}$ The Portland police behaved somewhat differently during a 1910 strike of iron workers. Responding to a call about a "freefor-all fight" between pickets and scabs, the police dispersed the combatants with the use of clubs and arrested a leader from each side of the brawl. 16

Although it is not known whether the inaction of the Seattle police or the well-controlled manner of the Portland police were the normal responses of these police forces to labor unrest before 1912, the above-cited instances at least provide an idea of what early police-labor relations were like in Seattle and Portland. It must be reiterated that the Seattle and Portland police did not have a great deal of experience in dealing with labor disputes prior to 1912. Moreover, it should be recalled that both police departments had been in existence a relatively short period of lime before 1912 . Thus in 1912, though the Wobblies were emerging as a force in the

*The reason for the mob's action was that some native-born workers felt that Chinese workers were crowding them out of the labor market. 
communities of Seattle and Portland, the police in these cities lacked tradition of coping with labor radicalism. Just what the police did in their encounters with labor radicals from 19121920 is the subject of the next six chapters of this dissertation. 
REFERENCES--CHAPTER III

1. News, October 29,1913, p. 1.

2. Mark C. Haller, "Historical Roots of Police Behavior: Chicago, 1890-1925," Law and Society Review, 10 (Winter, 1976), p. 318.

3. George Rude, The Crowd in History (New York: John Wi ley and Sons, Inc., 1964), p. 12.

4. Staughton Lynd (ed.), American Labor Radicalism (New York: John Wiley and Sons, Inc., 1973), p. 3.

5. Roger Sale, Seattle: Past and Present (Seattle: University of Washington Press, 1976), p. 127.

6. Ibid., p. 51.

7. Charles A Tracy, "Police Function in Portland, 1851-1874 Part I," Oregon Historical Quarterly, LXXX (Spring, 1979), p. 6; Dorothy Miller Kahlo, History of the Police and Fire Departments of the City of Seattle (Seattle: The Lumbermen's Printing Co., 1907), pp. 64-68.

8. Tracy, op. cit., p. 5; Kahlo, op. cit., p. 67.

9. Mayor's Message and Annual Report, City of Portland (Portland, 1912-1920); Annual Report of the Police Department of the City of Seattle (1912), op. cit., p. 12.

10. Mayor's Message and Annual Report (1912), op. cit., p. 60; Annual Report of the Police Department of the City of Seattle (1912), op.cit., p. 12.

11. Mayor's Message and Annual Report (1920), op. cit., p. 76; Annual Report of the Police Department of the City of Seattle (1920), op. cit., p. 10.

12. Kahlo, op. cit., p. 67; Sale, op. cit., p. 46; Murray ilorgan, Skid Road: Seattle: Her First 125 Years (Sausalito, Calif.: Coms tock, 1978), p. 91.

13. Morgan, op. cit., p. 91.

14. Kah10, op. cit., p. 67. 
15. Fred Thompson and Patrick Murfin, The I.W.W.: Its First Seventy Years (Chicago: IndustriaT Norkers of the Horld, 1976), p. 34 .

16. The Evening Telegram, December 7, 1910, p. 1. 
CHAPTER IV

THE POTLATCH RIOTS AND THE SEATTLE POLICE

The "Riots"

During the period of 1912-1913 the Seattle police related to labor radicals in much the same way that a spoon would relate to a hot toddy. The police had to stir a simmering mixture of labor radicalism, which included the I.W.W. and a strong Socialist Party. In the process of dealing with the labor radicals, the Seattle police were not only burned, they were scalded by the community's reaction to their handling of a particular series of events known as the Potlatch Riots.

The Potlatch Riots were more or less the stage upon which the police and the I.W.W. acted out a rolicking, wild scenario, which those with power and privilege used both the I.W.W. and the city police as pawns in a game of power politics. The riots themselves were a string of collective gatherings and disturbances that happened at the time of the Potlatch Days summer festival in Seattle in 1913. Actually, the "riots," as they have been referred to by newspaper reporters and historians, were not riots in the precise terms of what constitutes a riot. A riot in the true sense of the word is "a situation in which a number of mobs are simultaneously active in the same area." 1 None of the so-called Potlatch Riots fit this 
definition since there was only a single mob in action at one time in each of the disorderly and violent situations during Potlatch Days.

The first violent outburst during Potlatch Days involved intoxicated sailors who attempted to break up a Socialist street meeting on July 16,1913 . The sailors took over a soap box that had been occupied by Mrs. Annie Miller and they conducted a mock meeting. When Mrs. Miller tried to get the soap box back, one of the sailors raised his fist to strike her. A "large, well-dressed man, with a diamond ring, who bore no resemblance to the typical I.W.W.," stepped in and struck the sailor several times with his fist. ${ }^{2}$ Next, a fight started which developed into a "general melee" when the crowd which had been 1 istening to the speakers turned into a mos, attacking the drunken sailors. Sergeant Joseph T. Mason, who was patrolling the area, turned in a riot cal1* which brought a squad of police, a police captain, and three motorcycle police to the scene. The police were able to disperse the mob and to pull the military men from under the feet of their assailants. The police made no arrests because none of the injured could identify their assailants. ${ }^{3}$

Even though the Seattle police were able to rescue the sailors from the mob, the Seattle Times charged Seattle Mayor George $F$. Cotterill and the police with "dereliction of duty." Also, the Times mistakenly claimed that Mrs. Miller was a Wobbly and that

*A riot call consisted of a policeman informing an officer at police headquarters that some type of disorderly situation, involving two or more persons, was either in progress or likely to occur. Riot calls were often made in regard to incidents that were not riots. 
"red flag worshippers" and "anarchists" had beaten up two police officers and three soldiers. ${ }^{4}$ These details as well as other parts of the account of the event amounted to bald-faced lies. The lies were exposed several days after the disturbance when sworn affidavits of persons who saw or took part in the melee on July 16th indicated that Mrs. Miller was not a member of the I.W.W. and that no one was seriousty injured in the fracas. ${ }^{5}$

Subtle threats and warnings in addition to these falsehoods were contained in the July 17th issue of the Times. The Times commented that its reporters had "heard" citizens state that the "real patriots" should rise up in wrath and do the Mayor's job for him by "cleaning out the reds." In addition, the Times prophetically noted that the Seattle police had been notified two times that a group of enlisted men would "circulate about" the I.W.W. headquarters on the 18 th. ${ }^{6}$

Pandemonium and lawlessness reigned in Seattle on the night of July 18th. ilob violence broke out when a party of uniformed men entered I.W.W. headquarters while the I.W.W. was holding a street meeting. A street cop turned in a riot call and by the time that a squad of police had answered the call, the invaders had already gained entrance to the headquarters and had begun to carry out a scheme of destruction. Desks were smashed, chairs hurled against the wall, and literature was thrown out of windows. ${ }^{7}$ The Wobblies, upon learning of the attack on the office, ran from the street meeting to I.W.W. headquarters in an attempt to stop the soldiers and sailors. The Wobblies' efforts to defend their property 
failed miserably and the military men had no trouble "downing the wage slaves" in an exchange of fisticuffs. ${ }^{8}$

By this time nearly 5,000 spectators had gathered about the

I.W.W. headquarters. The Seattle Times described the remainder of the riot in colorful, yet accurate terms:*

Cries of "Fourth and Fike" sounded, and the little vanguard, backed by a small number of excited civilians, shot up First Avenue, crossed over to Second at the double quick, east on Pike, and drew up at ilillard Price's newsstand. . . Half a dozen hands seized the Socialist newsstand up against the curb and in a second papers and pamphlets filled the air.

The stand emptied, the soldiers and sailors of the vanguard, numbering no more than a dozen, overturned the stand and began to demolish it. . . The avengers had noted that the stand was painted red. "Smash everything that's red," shouted one of the party, as he laid the last whole board [of the stand] on the curb and descended on it with his No. 10's. ... From somewhere about the stand one of the sailors plucked a red flag. . . This was torn to tatters. Matches were quickly applied [to the remains of the flag] and the odor of burning rags presently told of the destruction of the I.W.W. emblem. [Near] the Socialist newsstand stood a stand where daily newspapers are sold. . . A Soldier ran over to the other cart and stuck an American flag among the papers in the top rack. When the willing workers made for that stand too, thinking it of the same breed as the one just smashed, they spied the flag and promptly moved back. Heads were bared and cheers for the flag drowned the roar of Pike Street traffic. . . . [Next] ... the little band broke into a run down Pike Street to Third Avenue, thence north toward the Socialist headquarters at 1909 Fourth Avenue. By this time a crowd of more than 1,000 civilians trooped along to see the fun.

The headquarters escaped with a broken window. . . A soldier, loudly applauded by the crowd . . climbed with an American flag... to place it over the window cof the Socialist headquarters].

The little band now headed south to 01 ive Street and at 01 ive Street broke into a run eastward. The crowd that

*There were no major discrepancies between the Times report of this disturbance and the Seattle Star's version of the same event. For the Star's account, see the Seattle Star, July 19, 1913, p. 1. 
followed was now blocks long and included men, women, and children. Automobiles brought up the rear.

The parade terminated at 71101 ive Street. At that place stands a dilapidated oid church said to be used as a branch headquarters of the "direct action" Socialists. . . Rushing up the shaky steps of the building, three or four of the leaders leaned against the old door, and it crumbled like a rotten shingle. .. The door smashed in, there was presently heard the crashing of glass in a half dozen places simultaneously. . . Much of the work was done with chairs or whatever came to hand, but when one of the more completely smashed windows burst out, a protruding foot told how the deed was done. Everybody cheered for the foot. A second later another pane crashed, and at the open window appeared a soldier with an American flag. Waving the flag wildly, he shouted "Hurrah for the American flag, down with the I.W.W.'s."9

There were no dissenting votes to the military man's suggestion to smash the I.W.W., no mobocrats* were arrested by police, and in general, no serious effort was made by the police to stop the ravaging of property.

Mayor Cotteri11, not the police, made the next move. Asserting the emergency powers of the office of mayor on the 19th, Cotterit1 assumed control of the police department. He then ordered the Times to suspend the publication of all issues for the next two days, demanded the closing of all saloons, and called for the breaking up of all meetings. 10 The police were an important part of Cotterill's plan. Twenty-five policemen were dispatched to the Times building where they closed down the newspaper. The police were also charged with the responsibility of enforcing Cotterill's orders regarding saloons and street meetings. ${ }^{11}$ All of this was done in the name of riot prevention.

*A mobocrat is a person who attempts to accomplish an end through rule by the mob. 
Cotterill's attempt to gain control over an explosive situation was quickly undone by a court order restraining Police Chief Claude G. Bannick and him from preventing the printing and circulation of Seattle Times newspapers. Cotterill's command to close down the saloons were also overturned by a court order. Instead of Cotterill's plan, the community of Seattle received United States military troops. Shore police from a Navy fleet and military police from a nearby Army camp were imported to assist the local police in keeping the peace. $^{12}$ Surprisingly, order was maintained for the remainder of the summer festival.

The absence of disorder, however, did not mean that the work of the city police was finished. Deciding to make "political hay" out of the July 18th disturbance, the I.W.W. held a series of evening meetings on the streets of Seattle. This time it was the merchants who complained about the Wobblies. They contended that I.W.W. street meetings hurt trade in their stores. The police responded to the businessmen's complaints by dispersing crowds and by arresting speakers at I.W.W. gatherings. For example, on Ju7y 21 st the Seattle police broke up a crowd of over 2,000 at an I.W.W. meeting. ${ }^{13}$ A7though the Wobblies persisted in holding meetings, the constant intrusion of the police into their propogandaspreading efforts, eventualiy contributed to the abandonment of the alleged riot issue by the I.W.W.

\section{Police Behavior in the Potlatch Disturbances}

At this point a closer inspection of police behavior during the Potlatch unrest is required in order to explain police inaction 
as well as police action. Before, during, and after the so-called riots, the Seattle police department was a focal point of attention. To some degree, the police like the radicals, were the "victims" of a whirlwind that swept through the city in July 1913. The police were roasted in print by the Seattle Times and the U.S. Navy Board of Inquiry for their neutral posture in the July 16 th braw7; ${ }^{* 14}$ they were crucified in a report for being too biased in favor of the sailors and the local mobs in the July 18th disorder by the U.S. Navy's Board of Inquiry; ${ }^{15}$ and they were even blamed for the actual occurrence of mob violence on July 18 th by the Socialists. ${ }^{16}$ Only Mayor Cotterill defended the police. 17

The Times treated the July 16th incident as though it could have been prevented if the police had suppressed public speaking by labor radicals and had confiscated their red flags. ${ }^{18}$ The U.S. Navy Board of Inquiry agreed with the Times' critical assessment of the police role in the melee of July 76 th. $^{19}$ The Board charged that the police were lax in permitting Socialists and Wobblies to heap abuse upon the military in the streets of Seattle. Moreover, the Board complained that the three servicemen involved in the melee were taken into custody by the police without a charge and that concurrently no charges were filed against the I.W.W.

In regard to the mob actions on the 18th, the Board claimed that the small number of entisted men in the disturbance could have

*The U.S. Navy Board of Inquiry was appointed by the Commander in Chief of the Pacific Reserve Fleet to investigate the Potlatch Riots. 
been checked by the police. Exactly how many enlisted men and policemen were at the I.W.W. headquarters is not known. However, the Board estimated that 20 to 30 men of the Navy and Marine Corps cormenced the plundering procession. 20 The Times stated that a "squad" of police arrived at I.W.W. headquarters. ${ }^{21}$ Given that a police squad consisted of six to eight men in 1913, it would seem that a squad of police, using some type of force, may have been able to stem the tide of unrest through early intervention.

Another one of the Board's allegations was that the police were too conspicuous in their support for actions of the mob. According to the Board, it was all too evident from police conduct during the riot that the police were in sympathy with the acts of those who were destroying property. : fore specifically, the Board charged that Seattle police officers were among the crowd that followed the military men along the path of destruction. The inaction of these police, in the Board's view, provided an unofficial sanction to the disturbance. In addition, the Board reported that no formal complaints were made against the enlisted men by the police authorities in Seattle. Based upon these and other "findings," the Board concluded that the responsibility for the mob violence on the 18th should be placed on the police because they took no effective steps to prevent the mob from carrying out its ruinous work. ${ }^{22}$

The Socialist Party also blamed the police for the outbreak of violence on the 18th. Millard Price, one of the leaders of the local Socialist Party and the one whose newsstand had been destroyed by the mob, declared that the police could have stopped the military 
men and thus saved his property. He told a Seattle Star reporter that the Socialists on learning of the military men's plans in advance, asked for police protection. However, Chief Bannick sent only two men to patrol the area surrounding the Socialist headquarters, according to Price. 23

Price's point about the inadequacy of the response of the police appears to have some merit. The complete saturation of an area with police was the standard response of the Seattle police to predicted mob violence or to an actual riot call. Then, too, it seems fitting to at least raise the question of whether or not more police would have been dispatched if the Seattle Times offices had been threatened and then besieged by Wobblies. In the same vein, it can be asked, "would the police have been more likely to use force to stop the mob if the mob had been composed of Wobbles and the mob's target had been the property of 'respectable' citizens?" Price as well as the Board of Inquiry no doubt would have answered both questions in the affirmative.

Mayor Cotterill took an entirely different and self-serving position in regard to police actions during Potlatch Days. He maintained that a "debt of public gratitude" was due the Chief of Police and the officers under his command for "tactful service" performed under "great difficulties" on extra sime "beyond the regular hours and compensation nolice work. "24 On the topic of the skirmish on July 16th, Cotterill asserted that he would never use the police to suppress the free speech rights of the I.W.W. or any other group. He also pointed out that the police could not be expected to "crack 
down" on persons who waved red banners since there was no law or ordinance prohibiting the display of any flag in Seattle. ${ }^{25}$

On the issue of police conduct on July 18th, Cotterill averred that the police had acted wisely. "Had they interferred," he said, "there would have been mass bloodshed." 26 In support of Cotterill's contention, it should be noted that the Times reported that the I.W.W. headquarters was already in shambles by the time the riot squad arrived on the scene. ${ }^{27}$ Then, too, it is not clear that even squads of policemen would have matched the numerical strength of the enlisted men in the middle and later stages of the disturbance. Approximately 200 enlisted men of the Navy and Marine Corps had participated in the mob action by the time that it had run its course through Seattie. 28

Even if there had been as many policemen as servicemen present on the mob's route, the police still may not have been able to quell the disorder, given the nature of the crowd which took part in the disturbance. It is clear from articles in both the Times and the Star tinat the crowd was supportive of the military men's actions. ${ }^{29}$ "Supportive" may be an understatement. The Navy's Board of Inquiry observed that from their dress and appearance, many of the civilians in the crowd clearly belonged to the "better class of citizens." The Board offered these details on the activities of civilian "leaders":

*It was estimated by a correspondent of the Seattle Star that the crowd varied in size from 25,000 to 30,000 persons, depending upon the phase of the disturbance. In general, the crowd resembled a snowball, picking up more persons as the mob rolled along its course. 
The movement appears to have been led, or at least guided, by the citizens of Seattle, who constantiy gave notice and passed information among the crowd as to where the various Industrial Workers of the World and Socialist offices and rooms were and to which place the crowd would, after visiting one place, proceed to the next. It appears that after arriving at each of these Industrial Workers of the World and.Socialist places the citizens in the crowd took the lead in showing the men engaged either in wrecking these places or in taking out the furnishings and burning them in the street, where the entrances were and how the contents might be removed. 30

Besides the rational, calculating "gentlemen of property" who may have been the stage managers of the riot, other persons in the crowd were very emotional. These persons let out frantic cheers, howls, and screams each time either something red was smashed or something red, white, and blue was exhalted to a position of prominence. 31 Irrational behavior by some civilians in the crowd manifested itself in the wrecking of a gospel mission. The civilians discovered their mistake before the entire mission had been plundered, however, when they found that the red banners on the walls read "God is Love" instead of "One Big Union."*

As well as the apparent strengths in Cotterill's defense of tine police, there were at least two glaring weaknesses. In stating that the police acted wisely by not interfering with the mob's actions on the 18th because they wanted to avoid bloodshed, Cotterill implied that the Seattle police recognized that the mob was harming only property and that as a consequence they chose not to intervene for fear of endangering the lives of persons.

*One Big Union was an I.W.W. slogan, referring to the I.W.W. principal of organizing workers on the basis of entire industries rather than on the basis of crafts as the A.F.L. did in its operations. 
Cotterill's position was ingenuous. On the one hand, it is true that, for the most part, the mob attacked property rather than persons. The total property damage resulting from the July 18th melee was estimated to be from $\$ 3,000$ to $\$ 5,000$, while the only casualty reported was a Wobbly whose nose was broken. 32

On the other hand, there is no evidence to indicate that the Seattle police made it a standard practice to step aside when property was being smashed to bits, justifying their inaction on the grounds that is was "oniy" property and that someone might get hurt if they were to protect that property. Contrary to what is implied in Cotterill's stance, part of the law enforcement activities of the Seattle police department in 1913 were devoted to the enforcement of laws relating to property. Police records indicate that the police were busy arresting thieves, recovering stolen merchandise, and guarding stores, mills, and other business places in 1913. ${ }^{13}$ Hence, the protection of private property was an integral part of the day-to-day functioning of the Seattle police. It seems exceedingly doubtful that the Seattle law enforcement officers could have so easily discarded a concern for defending private property when such a concern was so integrally bound up with their role as police.

Cotterill's defense of the police was also defective on another count. By directing his statements exclusively toward the role of the police in the discurbances, Cotterin was at le to abdicate his own responsibility for police policy. Under Seattle's council form of municipal government, the mayor was supposed to be the elected official who was most accountable for police behavior. 
With a politician's sleight-of-hand, however, Cotterill was able to avoid a discussion of the real issue of whose interests were served by the actions of the Seattle police during the Potlatch Day's disorder.

\section{Class Politics and Police Policy}

Setting aside the issue of who should be blamed for the Potlatchrelated violence, it is useful to analyze police behavior in terms of the political context of the disturbances. At the time they were in full swing the so-called Potlatch Riots were billed by the Seattle media as involving a battle to preserve the American way of life. In reality, however, this was not a fight for or against the flag. The key fact behind all of the Potlatch-related incidents was that the city of Seattle was going through a mighty upheaval in which organized labor including its radical elements, was aligned with the churches, the social clubs, and the civic and reform organizations against a loosely connected network of powerful men and interests headed by J. D. Farre11, the vice president of the Great Northern Railroad. 34 Linkages between the legitimate business community, city politicians, the police, and organized vice constituted the most important aspects of this network.*

In essence, the political context of the Potlatch Riots was the classic early twentieth century power struggle between reformers and machine politicians. Seattle reformers obtained a "wedge" to

*A similar combination of the business, political, police, and criminal interests was discovered in a study of social iife in Seattle in 1971. See William J. Chambliss, "Vice, Corruption, and Power," Wisconsin Law Review, 4 (1971), pp. 1130-1155. 
force their way into city government when a recall amendment was inserted into the city charter in 1906; the passage of a women's suffrage amendment in 1910 set the stage for the recall of machinesupported Mayor Hiram C. Gill in 1911.35 Gi11, a Democrat, was defeated by George W. Dilling, a Progressive Republican, in a recall election in which the point of contention was an "open" versus a "closed" town. Gill and Chief of Police Charles W. Wappenstein,* Who was Boss Farrell's personaliy selected chief of police, promoted the unobstructed perpetuation of gambling, prostitution, and other forms of vice in Seattle, while the reformers favored the suppression of all vice. The police response to Socialist and I.W.W. activities was not an issue presumably because the patriotic passions of the citizens had not yet been raised the the reality of war and by the Seattle Times' propaganda.

During Gill's first term in office his tolerance for all kinds of vice was matched by his willingness to at least put up with the varieties of labor radicalism that existed in Seattle. Apparently, neither the Socialist Party and the I.W.W. nor the A.F.L. local unions were sufficiently enamored by Gill's position regarding labor radicals to support him. In fact, organized labor was responsible for the circulation of petitions to recall Gill. $\star * 36$ Newly enfranchised

*Chief of Police Wappenstein was later tried, convicted, and sent to the Uashington State Penitentiary for accepting a bribe from two operators of "bawdy" houses in Seattle in 1912.

**The recall process in Seattle's municipal government operated as follows: if the signatures of one-fourth of the registered voters were collected on recall petitions, a special election would be held. The name of the official under attack and the names of candidates nominated by local political constituencies were placed on the ballot. If the incumbent received more votes than any of the challengers, the incumbent remained in office; if another candidate received a plurality, the incumbent was recalled. Murray Morgan described this process in Skid Road: Seattle: Her First 125 Years (Sausalito, Calif.: Comstock, 1978), p. 172. 
women were another group that was active in the recall of Gill. Some political analysts have even gone so far as to claim that the female vote was the decisive factor in the 1911 recal1. ${ }^{37}$ At the very least, it can be stated that Dilling was elected and finished out what would have been Gi1l's term in 1911, in part, because of the efforts of Seattle women.

So far as the riots are concerned, it is essential to understand the class politics involved in the 1912 mayoral election that followed the recall. The critical point is that George Cotterill, a Progressive Democrat, was able to defeat Gill, his opponent, because Cotterill was supported by a coalition of middle class Progressives and working class people. ${ }^{38}$ This was an uneasy coalition due to the antagonistic interests held by the middle and working classes. The fundamental contradiction manifested itself in the issue of "reform." Reform for the middle class meant the prohibition of alcohol, gambling, and other vices, the abolition of entrenched political machines, and the establishment of a middle class dominated power base. To a sizable segment of the working class, however, reform meant pro-labor public policy and radical social change.

When Cotterill took office, he had to maintain this tenuous coalition as well as ward off attacks from the opposition. The

*For an excellent analysis of the relationship between militant workingmen and liberals in the early twentieth century, see Eugene $M$. Tobin, "Direct Action and Conscience: The 1913 Paterson Strike as an Example of the Relationship Between Labor Radicals and Liberals," Labor History, 20 (Winter, 1979), pp. 73-88. 
latter concern turned into a source of continual annoyance for Cotteri11. From the beginning of the 1912 mayoral campaign through the Potlatch Days Colonel Alden J. Blethen, the owner of the Seattle Times and an advocate of an "open" town, utilized the pages of the Times to make appeals to the patriotic passions of the Seattle citizenry in hopes of weakening Cotterill's support. In particular, the Times criticized Cotterill for not employing the police to suppress I.W.W.-sponsored demonstrations in early 1912. The demonstrations were for Leonard 0lsson, a Wobbly who fought to have his citizenship restored by the courts. Blethen also blamed Cotterill for allowing the Wobblies to bear a red flag in a May Day parade in Seattle in 1912.40 The troubles between Cotteri11, Blethen, and the I.W.W. became more and more rancorous until they exploded in the face of Cotterill and in the presence of the Seattle police during the 1913 Potiatch Days.

In retrospect, it now appears that the class composition of Mayor Cotterill's political base was a key factor in the shaping of the police policy toward the Hobblies and the Socialists during those violent and disorderly days in the summer of 1913. While the tumultuous events of Potlatch Days were in motion, Cotterill had to counterbalance the interests of the working class union people, who had supported him, with the interests of the Seattle Times, which had backed his political opponent. At the same time, Cotterill had to consider the interests of middle class merchants whose profits would have been reduced if he had either locked up all of the mobocratic military men upon whose money the economic success of the 
Potlatch festival partially depended or allowed I.W.W. street meetings to scare away middle class shoppers in the days following the mob violence.

The end product of Cotterill's attempt to mesh these clashing interests was a police policy of minimal intervention. To a certain extent, a policy of little or no police action was dictated by the fact that the main elements in Cotterill's political base, namely the middle and working classes, were set in opposition to one another. In this situation of political stalemate the problem of labor radicalism presented such difficulties to Cotterill's fragile base of support that an attempt to resolve the problem in favor of any of the affected parties may have had disastrous political consequences for the Mayor. Ironically, the policy of minimal intervention served to heighten the antagonisms between the middle and working classes by making their antithetical interests more noticable. This was the result, even though cotterill apparently intended to appease both classes. 
1. R. Kelly Hancock, "Collective Behavior and Social Movements," in Reece McGee (ed.), Sociology: An Introduction (Hinsdale, 111.: The Dryden Press, 1971), p. 569.

2. Sun, July 20,1913, p. 1.

3. Daily Times, July 17, 1913, p. 1.

4. Ibid.

5. Sun, July 20,1913, p. 1.

6. Times, op. cit.

7. Daily Times, July 19, 1913, p. 1.

8. Ibid.

9. Ibid.

10. Post-Intelligencer, July 20, 1913, pp. 1, 2.

11. Daily Times, August 19, 1913, p. 1.

12. Sun, July 20,1913, p. 1.

13. Oregonian, July 26,1913, p. 4.

14. Daily Times, JuTy 18, 1913, p. 1; Bremerton News, August 23, 1913,

15. Bremerton News, op. cit.

16. Star, July 19, 1913, p. 1.

17. Sun, July 20, 1913, p. 1.

18. Daily Times, July 18, 1913, p. 1.

19. Bremerton News, op. cit.

20. Ibid.

21. Daily Times, July 19, 1913, p. 1. 
22. Bremerton News, op. cit.

23. Star, July 19, 1913, p. 1.

24. Sun, July 20,1973, p. 1.

25. Ibid.

26. Star, July 19, 1913, p. 1.

27. Daily Times, July 19, 1913, p. 1.

28. Daily Times, op. cit.; Star, op. cit.; Bremerton News, op. cit.

29. Daily Times, JuTy 20, 1913, p. 1.; Star, July 19, 1913, p. 1.

30. Bremerton News, op. cit.

31. Star, op. cit.

32. Ibid.

33. Annual Report of the Police Department of the City of Seattle (Seattle, 1913), p. IT.

34. Murray Morgan, Skid Road: Seattie: Her First 125 Years (Sausalito, Calif.: Coms tock, 1978), pp. 164-193.

35. Roger Sale, Seattle: From Past to Present (Seattle: University of Washington Press, 1976), pp. 86-93, Morgan, op. cit.

36. Morgan, op. cit., p. 175.

37. Ibid.

38. Sale, op. cit., p. 91.

39. Ibid.

40. Lowell S. Hawley and Ralph Bushnell Potts, Counsel for the Damned: A Biography of George Francis Vanderveer (Philadelphia: [ippincott, 1953), p. 144 cited in Robert L. Tyler, Rebels of the Woods: The I.W.W. in the Pacific Morthwest (Eugene: University of Oregon Books, 1967), p. 45. 


\section{CHAPTER $V$}

ROWDYISM, REFORN, RIOT, AND REPRESSION IN PORTLAND

Police Policy Under the Rushlight Administration

Labor radicalism became a thorny problem for the Portland police in the latter part of 1911 and in 1912. During these years the Wobblies and Socialists began to hold rowdy street meetings, using abusive and profane language which brought complaints from the "decent" citizens of the city." Mayor A. G. Rushlight, a Republican by party affiliation and a plumber by trade, had to deal with the complaints since he held authority over police officers.

To some extent, the nature of Mayor Rushlight's political constituencies predisposed him to allow working class protest in Portland. His power seems to have derived, in part, from certain Wealthy Republicans, who had close ties to the "power broker" element in Portland. 2 This is not to imply that he always enjoyed complete support from the business community, but rather to point out Rushlight's connections to the old business-political establishment* in Portland which was in a state of decline in 1912. This old establishment had traditionally relied upon the working class as a wellspring of its political power. In Rushlight's case, the

*The "old establishment" in Portland consisted of business and professional leaders, most of whom were members of the wealthiest families in Portland. 
working class was a source of support, owing to his representation of this class in his former role as a councilman for southeast Portland. Vice interests may have been yet another component in Rushlight's political base. There is at least circumstantial evidence to indicate that Rushlight was linked to Portland vice interests. ${ }^{3}$ !What these bits and pieces of information seem to add up to is a mayor, styled in the genre of the traditional machine-supported official, but lacking a finely-tuned political machine.

One of Mayor Rushtight's first encounters with the labor radicals came in the Baden-Powe11 affair. Robert Baden-Powe11, the founder of the Boy Scouts, arrived in Portland in the spring of 1912 for the purpose of extolling the virtues of the scouting movement. A public debate was scheduled between Baden-Powell and Allan McDonald, the secretary of the I.W.W. local unions in Portland, but the full debate never took place because Baden-Powell was heckled during his initial presentation. ${ }^{4}$ Unidentified rowdies shouted down BadenPowell's efforts to speak; the rowdies yelled and hooted about the militarism that allegedly inherred in the scouting movement.

The Spanish-American War Veterans and the Realty Board* were so upset by the outcome of the quasi-debate that they passed a resolution, blaming the Socialist Party and the I.W.W. for preventing Baden-Powell from speaking and threatening :layor Rushlight with a recall if he did not stop soap box orators from speaking

*The Realty Board was an association of businessmen concerned with real estate affairs in Portland. 
on the streets of Portland. On the other side of the controversy, the Central Labor Council* of Portland criticized the Realty Board for advocating the suppression of First Amendment rights, defending Rushlight's stand in favor of free speech. As for the I.W.W., it denied any responsibility for the heckling. In a public statement the I.W.W. pointed out that since the I.W.W. secretary was invited to be a participant in the debate, there was no reason for the I.I.W. to disrupt the meeting. 5

Several days later the Portland News claimed to have uncovered a "plot" to incite a riot at the Baden-Powell meeting. ${ }^{6}$ According to the News, the hecklers were hired by the Employer's Association** and other local business interests to create a disturbance in order to force Rushlight to use the police against organized labor. Interestingly, the News stressed that most of the members of the Employers' Association were "keen businessmen" who were practically blameless in the Baden-Powe 11 flare-up. Those behind the plot, in the News' opinion, constituted a smal1 minority of "radical labor haters" who had taken control of the Employer's Association. 7

The News' "evidence" of a plot was flimsy and not sufficient to convince any reasonable person of the existence of a conspiracy. Moreover, the matter of the alleged plot was dropped as an issue

*The Central Labor Council was composed of representatives from local unions that were affiliated with the American Federation of Labor (A.F.L.).

**The Employers Association was an organization of Portland businessmen who formalized t'neir affiliations in order to enlarge their control over the local economy. 
by the press soon after it was first introduced by the News. What pricks one's curiosity, however, is the revelation that the police were a primary source of information for the News in its attempt to outline the alleged plot.* The News stated that it was the plan of the police to follow the "trouble-makers" at the Baden-Powell debate to their rooms and to arrest them unobtrusively in order to prevent a demonstration by people who thought that a "bona fide Socialist" was being persecuted. Unfortunataly for the police, the alleged hecklers evaded them at the end of the meeting. ${ }^{8}$

These types of police actions apparently were not uncharacteristic of the ways in which the Portland police handled labor unrest in 1912. In fact, the general police policy toward labor during the early months of the Rushlight regime seems to have been one of toleration. While Rushlight served as mayor, the police allowed street speakers the right of free speech and permitted union pickets to gather in front of a struck plant. Commenting on the police policy under the Rushlight adminstration, the Portland News declared:

-. The police were instructed merely to preserve the peace and order and to take the side of neither capital nor labor, but to give each a square deal.9

Another major event involving the Portiand police and the labor radicals was a strike of women and girls at the Oregon Packing Company on Portland's eastside. The strike began when from 50 to

*That the police were informants for reporters of the Portland News should not surprise anyone who has perused issues of the paper for the years of 1911-1913. The News staunchly supported the police, often printing poems, letters, and other items written by street policemen. 
to 100 of the company's 250 workers walked out of the plant on June 27, 1913 because of extremely low wages and unsanitary working conditions. ${ }^{10}$ This dispute between the well-established fruit company and women fruit sorters had a "David versus Goliath" scenario. The women were both exploited and powerless, being paid only a 10 cent hourly wage and lacking union organization. They received a substantial amount of support from members of the I.W.W., the Socialist Labor Party, and independent Socialists who supplied aid to them in the form of fund raising, housing, food, and baby-sitting. Most importantly, the radicals organized the women workers and represented them in negotiations with the management of the packing company. The Oregon Packing Company, in contradistinction to the fruit sorters, was a powerful inter-state corporation. In point of fact, the "Oregon Packing Company" was merely a local name for the California Fruit Canner's Association. This Association controlled the market in canned goods in the West; it was a multi-million dollar concern, setting prices and making substantial profits. In California, the majority of the fruit packing plants were controlled by the corporation and, at the time of the cannery strike, the Association owned plants in Portland and Salem, Oregon. Cheap labor was a keynote in the corporation's success. The Association made heavy use of the cheapest type of immigrant labor in California, whereas the corporation refused to pay the women even subsistence wages in Portiand. 11

The police became involved in the dispute between the women and the company on the second day of the strike. When the inexperienced 
strikers set up a picket line, some police tried to intimidate them by zooming up to the picket line in a patrol car whose bel1 was clanging. When the officers jumped out of the car hurriedly, the women expected a raid which never occurred. Later a police captain explained to the press that this was only part of the routine changing of officers from the night to the day shift. ${ }^{12}$

other minor forms of police harrassment were employed in the first days of the strike. Police Captain Moore, apparently upset by banners reading "Forty cents a day makes prostitutes" and "A dog wouldn't scab," incorrectly informed the women that according to city law they could not carry banners. ${ }^{13}$ other police officers told the strikers that they could picket, but that "calling anybody a scab" would be grounds for an arrest. ${ }^{14}$ In spite of this chicanery on the part of the police, the strikers continued picketing in from of the plant, occasionally mounting a tar barrel in order to urge those still working to join them.

In contrast to these measly attempts to frighten the women strikers, Guy Fuller, a patrolman, sided with the strikers. Fuller even composed the following poem which was used by the women to publicize their situation:

I have seen men gaunt and weary waiting for a strike to end. Waiting for a chance to labor for the homes they must defend. There's a strike now in our city, going on this very day;

A demand by girls for wages for a soul-sustaining pay-Wages that will buy them clothing-give them decent food to eat; Keep their souls from being bartered to the vice clique of the street. 
This is but one strike in many on "the roads that lead to Rome":

Look about you! See the menace to your country and your home. See the mothers bent and broken 'neath their heavy burdens bowed;

See the fathers! See the children! It's the weary, motley crowd--

Pitiful, emaciated, soul-appalling in their need!

Crucified with the spikes of hunger on the sordid cross of greed!

know the product of such suffering isn't all your money buys.

But the soul of the producer is a purchase-given prize;

For whenever strikes are ordered and the flag of want unfurled, Human lives are being bartered in the markets of the world. 15

The pro-labor poem by Fuller and the petty harrassment by Moore and other officers indicates that the police themselves may have been divided over the dispute at the cannery. The important point, however, is that the police did not forcibly remove the pickets from in front of the cannery. Instead they ailowed the strikers at least some degree of freedom in their protest actions.

\section{Police Policy and Municipal Reform}

A dramatic shift occurred on July lst in the police policy with respect to the labor dispute at the cannery. Mayor H. Russe11 Albee, a reformer, and a new administration, including a new police chief, were sworn in; also, the commission form of city government took effect on this date. The first act of incoming Police Chief John Clark was to order the strikers to "quit picketing . . . quit speaking . . quit parading, or else face a jail sentence." 16 The striking women reacted to the chief's order by issuing a 
statement of their own which read: "Bring on your injunction, bring on your patrol wagon and take us to jail, if that's the new police sys tem . . " 17

What caused the sudden change in police policy? Chief Clark would only say that he had received his instructions from "those higher-up." Mayor Albee and the other city commissioners were no doubt some of the persons to whom $\mathrm{Cl}$ ark vaguely referred as having formulated the new police policy. The mayor and all of the commissioners were no doubt some of the persons to whom Clark vaguely referred as having formulated the new police policy. The mayor and all of the commissioners were at least inclined because of their social backgrounds to favor business interests in labor disputes. Albee himself was an insurance executive, while the rest of the commission was composed of a manager of a type company, a civil engineer, a manager of a department store, and an attorney. ${ }^{18}$

In addition, these cormissioners were not as accessible to the influence of members of the working class as were the councilmen which they replaced. The reason for the reduction in the political clout of the working class related to the replacement of district or ward representation by a system in which each commissioner was elected city-wide. The commission form of government with its city-wide elections tended to dilute working class political power which traditionally had a ward or precinct locus in Portland. The decrease in working class power was revealed in the fact that two members of the Council in the Rushlight administration rapresented organized labor, whereas none of the commissioners in 1913 represented labor's interests. 
The sheer number of city officials may have been another factor that contributed to the policy change. Formerly power was dispersed among 15 council members, but now power became concentrated in the hands of five commissioners. Although the mayor generally exercised authority over the police in both the council and the commission forms of government, there were considerably fewer officials who could create problems for a mayor in the role of Commissioner of Public Safety than there were for a mayor in the role of strong executive in the council form. In short, a mayor was likely to have a less obstructed reign over the police department under the commission as compared to the council type of government. In the case of Mayor Albee, the process of establishing a probusiness police policy may have been less cumbersome than the process would have been with a 15-person city council.

Sources of influence besides the mayor and the commission also affected police policy. A clue as to the identity of these other sources can be found in a conversation held between a committee representing the strikers* and Chief of Police Clark on July 1 , 1913. The News interviewed three witnesses to this conversation and printed this reconstructed dialogue:

*The committee consisted of Tom Burns, :lary Schwab, and Mrs. McDonald. The first two were Socialists, while Mrs. McDonald was one of the striking cannery workers. Burns, a flamboyant and independent Socialist, was known as the "mayor of Burnside" which is an area in the heart of Portland's skid road district. 19 !lary Schwab was an organizer for the Socialist Labor Party.20 As for :Irs. McDonald, no information on her background or activities could be found. 

Chief Clark: "You can speak on a vacant lot, but you can't speak on the street under the law. . ."
Committee: "Oh yes we can. You had better look up the law..."
Clark: "The girls were offered a dollar a day."
Committee: "They never received such an offer."
Clark: "A girl can live on \$6 a week."
Committee: "A girl can't live like a self-respecting, honest, white girl on $\$ 6$ a week. You treat us like Chief Slover* did and you'll have no trouble in this town. You try to shut off free speech and we'll fill your jail."21

Clark's statement that the "girls were offered a dollar a day" is significant in light of the fact that this offer was not publicized until two days later. The "offer" to which $\mathrm{Clark}$ made reference was based upon an agreement between the Industrial Welfare Commission and the Oregon Packing Company. Since Chief $\mathrm{Clark}$ cited this offer as part of the rationale for his policy, a brief exploration of the nature of the relationship between the Industrial Welfare Commission, the fruit packing company, and the Portland municipal government is in order.

The Industrial Welfare Commission was formed in the spring of 1913 under an act which passed the Oregon State Legislature almost unanimously and without regard to political party affiliation. 22 The act was sponsored by the Consumer's League of Oregon** and

*E. A. Slover was the Chief of Police in the Rushlight regime. A sort of relaxed person, Slover made a practice of napping near the stove at police headquarters. As a police captain under the Albee administration, Slover was dismissed because of his alleged relationships with vice interests in the latter part of 1913.

**The Consumer's League of Oregon was composed of persons from the business and professional fields who generaily shared a progressive ideology. 
supported hy the data contained in a policy research report authored by the same group entitled "Welfare Legislation for Women and Minors."23

The advantages of an Industrial Welfare Commission were stressed in the report issued by the Consumer's League. Some of the al leged advantages reflected a sort of "parens patrie"* perspective. For example, the report stated that the Industrial Welfare Cormission would promote the welfare of the state of Oregon because it would "protect the women workers . . . from the economic distress that leads to impaired health and inefficiency." 24 0ther reasons given on behalf of creating the Cormission were humanitarian in nature. It was pointed out, for instance, that the Commission would "prevent exploitation of helpless women" and eliminate "sweating" in the state's industries. 25

Still other alleged advantages of the proposed legislation involved benefits for employers. One supposed advantage was that a Commission would furnish women employees with a means of obtaining "the best minimum wages... without recourse to strikes or industrial disturbances."26 In other words, a Commission would institutionalize and routinize conflict resolution, eliminating unexpected strikes that were harmful to employer profits and disruptive of employer planning schemes. A second advantage to the employers, according to the Consumer's League report, was that a

*Parens patrie refers to the idea that certain categories of people, especially juveniles, require the protection of the State which acts in the role of a surrogate parent. 
Commission would enable employers "to prevent the undercutting of wages by less humane and considerate competitors."27 Translated into terms that certain employes could more readily understand, this meant that the Commission would assist the larger businesses in eliminating the small ones.

As a whole, the report represented a blend of liberal benevolence, welfare statism, corporate capitalism, and Christian charity. In addition, the report contained elements of feminism. For example, the authors of the report emphasized that it was unreasonable and unfair to suppose that women can be paid substandard wages because they were supported by men. As a corrective to this erroneous way of thinking, the authors pointed out that women served as the main breadwinners in many families. Moreover, the authors asserted that "social justice" was not served when low wages were paid to workers by reason of their womanhood and youth. ${ }^{28}$

The Industrial Commission law itself was one of the most farreaching welfare laws in the nation. The Commission possessed the statutory power to fix the wages, hours, and working conditions of all females and minors employed in any industry. 29 In terms of the membership of the Commission, common sense indicates that industrial justice could only be served if representatives of both capital and labor were appointed to the Commission. This was only nominally the case.

The first Commission consisted of Amedee M. Smith, representing the employers, Mrs. Bertha Moores, representing the 
the employees, and Edwin W. O'Hara serving as Chairman of the Commission.* An inspection of the social backgrounds of the members reveals that labor lacked bona fide representation on the Commission. 0'Hara was the assistant pastor of the Cathedral of the Immaculate Conception; Smith was the third vice-president of the Realty Associates of Portland; Moores, the designated representative of labor, was the daughter of a pioneer sawmill operator, the sister of C. B. Moores (who was the president of Moores Motor Car Co., and later a Republican candidate for Secretary of State in Oregon), and herself active in "the commercial field" and a prominent clubwoman. 30

While the original purposes and eventual outcomes of some urban policies may be quite different, this was not the case with respect to the Welfare Commission. The Commission functioned just as it was planned to function. Within a few days after the strike commenced, the Oregon Packing Company submitted the question of wages to the Commission. Acting with lightning-like speed, the Commission announced on July 3, 1913 that it had reached an agreement with management (not labor). The agreement was that a one dollar a day minimum wage would "go into effect immediately. "31 The Oregon Packing Company jumped at the Commission's first offer. As Manager McPherson of the company stated, "we did not wait 30 or 40 days, but immediately agreed. . ."32 The strikers,

*ivo change occurred in the composition of the Commission from its inception to 1976 . 
however, refused to agree to an arrangement to which they were not privy. Tom Burns, a member of the strike committee, responded to the offer in these words:

The Industrial Commission which butted into this affair is composed mainly of parlor reformers, and it seems to me that their principal function is to break the strike. 33

A consequence of the Commission's offer was that it assisted the company in managing in community's impression of the strike situation. By submitting the wage issue to a purportedly neutral body for arbitration, the company made it appear that it had dealt with the strikers in "good faith." To the extent that this impression became accepted by various segments of the community, the company was able to increase its control over "third parties" to the labor dispute. Apparentiy, Chief Clark was one of those who was persuaded by the company's bureaucratic strategy. Police policy was shaped by other sources as well as the Industrial Welfare Comission. The Portland Employer's Association and the Eastside Businessmen's Club* brought "tremendous pressures" to bear upon the mayor and the police chief to prohibit speakers from using the streets in the vicinity of the cannery. ${ }^{34}$ The Employer's Association allegedly hired spies and detectives to ask residents near the plant to complain about the pickets and the strike committee to the police. Taking a less surreptitious approach, in a closed meeting with the mayor the Eastside Businessmen's Club

*The Eastside Businessmen's Club was made up of persons who owned businesses on the eastside of Portland. 
demanded "definite and decisive action from the police department to end the meetings of the strikers and agitators and to keep them away from the packing plant. "35

The Portland "Free-Speech Fight" and Anti-Radical Police Violence

The pressures upon the police to put down the strike brought the first arrests at noon on July 9th. Three Socialists were arrested for speaking in front of the packing company; they were charged with "disorderly conduct" and "abusive language."136 Later in the day, :Mayor Albee ordered Chief Clark to forbid picket lines at the site of the strike. As a result, more women were arrested that day, some of whom were workers; Mary Schwab was taken into custody four separate times. ${ }^{37}$ By July 10th it was clear that the reform administration's police policy had ignited a "free speech fight."

The first police violence in the strike took place soon after the inception of the battle to preserve the right of freedom of speech in Portland. On July 13th the strikers were peacefully picketing in front of the cannery when the order to charge was given and six mounted officers galloped into the striking women. Several women were knocked under the horses' hooves and trampled, while another woman was crushed between two horses. Three women were injured in this police attack and two women were arrested by the Portland police. ${ }^{38}$

The following day it was discovered that 30 police officers were hiding in a barn close to the cannery; they vacated the barn after the owner ordered them to leave. ${ }^{39}$ The police showed up en 
masse again at the trial of Mary Schwab on the 15th when a reserve force of police met 1,000 strikers and sympathizers who had marched to the courthouse to learn the outcome of the Schwab trial. Policestriker contacts were peaceful on the 15th, in part, because Schwab was acquitted of the charges against her. ${ }^{40}$

That evening, ten speakers were arrested in downtown Portland in the typical I.W.W. free speech format--as one person was pulled off the soap box and arrested, another mounted the soap box and spouted ephithets damning the employing class. ${ }^{41}$ Multnomah County Sheriff Thomas Word was in charge of pulling speakers off the soap box and escorting the "criminals" to jail. Tom Burns was charged with "using profane and abusive language" and the nine other persons were charged with "disorderly conduct."42 City police assisted Word's deputies in clearing the streets. 43

On the 16th the police arrested three members of the strike committee while they were standing in front of the cannery. 44 The same day, as rumors spread throughout the city that I.W.W. gangs were headed for Portland to carry on the free speech fight, 45 ilayor Albee banned all street speaking except religious speeches. ${ }^{46}$ Deciding to test the Albee's anti-free speech rule, about one dozen women strikers along with a few Socialist and I.W.W. supporters assembled downtown in the evening on the 17 th "to tell tile people of this city something about conditions at the plant."47 A "large" crowd (of an undisclosed size) also gathered around the women strikers, expecting to listen to the usual tirades against the inequities of the capitalist system. 
Just before the public speaking was to commence, the Sheriff and a representative of the city police notified the women that they could not publicly discuss the strike. When the women tried to speak, a police riot* broke out in Portland. The Portland News described the activities of several groups of police, totaling around $200 \mathrm{men}$, in these colorfut terms:

A solid phalanx of blue-coats, extending from curb to curb, moved south on 6th street in close formation, ordering the tremendous crowds onto the sidewalks, while at the same time a squad of patrolmen counter-marched on each sidewalk undoing the work of the main body and forcing the crowd off the sidewalks again and back on the street. . . This maneuvering was maintained for fully 15 minutes until someone made the discovery that a blunder had been made in aligning the forces. . . .49

[Hext, the mounted police]... advanced in two straight ranks, one ahead of the other and one man to the horse. Up 6th . . . came the 2 lines of police cavalry. "Charge" yelled some fellow in front of the Lotus saloon, and the mounted heroes eagerly entered the fracas . . . for fully 30 minutes pandemonium reigned. The police marched back and forth, the deputies moved up and down, and the mounted officers galloped hither and yon. . . 50

The Oregonian described the riot in less dramatic terms:

When the police and deputies, after the first few minutes, failed to clear the streets, they were obliged to rush the crowd. More than a score were hit with clubs. At least 50 others were struck by fists in the melee. Many were knocked down. ...

*According to an authority on police violence:

An event is a police riot when roving bands [mobs] of policemen set upon nonprovocative persons and/or property in an excessively violent manner. When only one small group of policemen sets upon citizens and/or property in a single location it may be useful to call this a "police attack." A "police riot" is any such event involving two or more attacks. "Nonprovocative persons" are those who represent no significant threat to life, physical safety or property ...48 
Seventeen women, who were led by Dr. Marie Equi* and Mary Schwab, stood their ground in the teeth of a storm of violence. These women were intent on speaking even after the mounted charge and the mass clubbings. When they refused to go home as ordered by the police, Equi and nine other women were taken to the police station. At the station Equi stabbed patrolman Evans in the wrist with a hatpin. Evans had the wound cauterized at once since earlier in the day Equi had threatened to prepare such a weapon and dip it in a deadly virus. $^{52}$ Once Equi was corralled and brought under control, she was held on four charges--"disorderly conduct," "inciting a riot," "carrying concealed weapons," and "assault with a dangerous weapon." 53 Unfortunately for Equi, the police were not finished with her. One of the other women prisoners in jail told of Equi's brutalization by the city police:

Dr. Equi was abused most shamefuily..... When we arrived at the police station it seems that Chief Clark and his men took a special delite (sic) in tormenting her. She was roughly handled, and the language used toward her was vile. I think the people of Portiand should know something about the way their Chief of Police addressed this little woman while she was at his mercy. I neyer heard such vile language as that man used at her. ${ }^{2}$

The aftermath of the riot was nearly as wild and unbelievable as the police riot itself. Mayor Albee strove to avoid notice of the battle between the authorities and the protestors three days after the riot, announcing that he did not think there was a free

*Dr. Marie Equi was a highly competent medical doctor who was extremely active in the class struggle in the state of Oregon. She campaigned for women's suffrage, participated in labor strikes, spoke out against World War I, and fought on behalf of many progressive and radical causes. Equi served as a financial benefactor and counsel to militant working men and women in her later years. 
speech fight "going on."55 Yet, on the day prior to the Mayor's statement, the Chief of Police and the Sheriff passed down an order "to arrest all men and women who were on the streets without lawful business." 56 Horeover, at about the same time that the mayor was denying the existence of a free speech crusade, the police were busy arresting droves of men who did not have $\$ 10$ and a "boiled shirt" as well as men who were wearing red (I.W.W.) ties. 57 The charge was the same for all of those snared in the police dragnet-"vagrancy."

Most of the "vagging," as the police called it, was done by police detectives. On July 19th, for instance, a Portland police detective noted in his report book that he had worked "all day arresting I.W.W. who were vags as per orders." 58 The detectives did not exercise much selectivity in making these arrests. For example, it is instructive to examine the case of Gus Molkentin, a German workingman. Molkentin had been a Portland resident for over 15 years, possessed a bank account of $\$ 400$, and had worked as a common laborer for many years. Like a great many Germans, Molkentin liked his daily mug of beer. He stepped into a saloon for that purpose on July 20th and had hardly finished his brew when he was accosted by a plainclothes policeman. "You're an I.W.W., arent' you," the policeman stated. Even though Molkentin denied the policeman's assertion, he was arrested, booked, and vagged. ${ }^{59}$

The free speech fight continued until the first week in November, al though the cannery strike fizzled out at the end of July. By late summer the fruit packing season was passed its peak 
and the demand for labor was greatly reduced. These factors coupled with police repression contributed to the termination of the strike. As for the free-speech fight, when it reached a high level of intensity in late summer and fall, the city authorities, in effect, suspended the U.S. Constitution in Portland by prohibiting both the freedom of speech and the freedom of association. Despite the fact that the intent of this policy was to crush the free-speech fight, the extreme repression prompted local A.F.L. unions, influential middle class citizens, and some working class people to align themselves with Equi and others who had initially opposed the anti-free speech policy. ${ }^{60}$

In fact, the heavy dose of repression touched off drives to recall both Mayor Albee and Sheriff Word. Worse yet from the standpoint of the city's fiscal status, the fight against free speech cost the city of Portland thousands of dollars, disrupted the business of the police and other municipal departments, and blocked the transaction of public business in general. ${ }^{61}$ In addition, personnel fatigue problems surfaced in the city police department. Many of the policemen had little opportunity to go home and sleep, and vacations were cancelled because of the heavy utilization of men in policing the cannery strike and the free speech fight. Moreover, members of the police department were compelled by Mayor Albee to work from 10 to 14 hours daily during the unrest of 1913-1914. Additional1y, a two-day a month layoff which was allowed during the Rushlight administration was set aside by Albee. Mayor Albee was even warned about overworking the city 
police by the Oregon State Labor Commissioner, who told Albee that he would have to either reduce the number of hours worked per day by police officers or go to jail for violating a state law which limited public employees to an eight-hour work day! 62

The exploitation of police workers, the fiscal "crunch" of city government, and the growing public opposition to "police state" methods, however, did not halt the police violence. In fact, another police attack took place on October 29, 1913 when the police stopped a free speech meeting, pulling nine women off a soap box, one after another, and arresting them. Jean Bennett* was one of the women who was hustled into a police auto and driven to police headquarters. Bennett and the eight other women were held without charges and wi thout bail. $* \star 63$

While the fracas with the nine women was occurring on a city street, Mrs. Schwab climbed a telephone pole at a nearby intersection to deliver a speech; this stunt brought thousands of people to the intersection where Schwab's rhetoric was flowing freely from atop the telephone pole. Next, two police officers pulled her down from the pole and rushed her to jail in an auto. A large crowd started to follow Schwab to jail, but the crowd was met by a score of policemen who drew a rope across the street and began to club the heads of persons in the crowd. More than a dozen persons were

* Jean Bennett was a middle class reformer who played a prominent role in the Portland free speech fight in 1913.

**According to Mark Haller, the violation of suspects' civil liberties was a norm of police conduct in the early 1900s. See Mark H. Haller, "Historical Roots of Police Behavior: Chicago, 1890-1925," Law and Society Review, 10 (Winter, 1976), p. 303. 
assaulted and injured by the police; most of these persons were not free speech crusaders. ${ }^{64}$ Evident7y, many of the injured persons were merely on the sidewalks and could not get away from the clubs.

The community was outraged by this type of police action and Mayor Albee drew sharp criticism for the display of brute force by the police. Indeed, community "influentials" warned Albee that more serious protests against his anti-free speech policy and police violence were likely unless he aijowed Portland citizens the right to freedom of speech. 65 Albee finally lifted the restrictions on basic freedoms in early November of 1913 and the free speech fight was won.

Police Work With Juveni les: A Cloak for the Dagger of Repression?

It is important to appreciate the fact that proactive repression of the type that was executed by the Portland police in 1913 was only one side of the urban police function in the early twentieth century. Preventive strategies were not incongruent with the police riots and the outright attacks upon strikers and protestors. Police work with juveniles was perhaps the best example of a preventive activity that was conducted simultaneously with iron-fisted, military-like police activities.

The Portland Police Department initially became involved in working with juveniles in 1905 when Lola Baldwin was hired to handle "wayward" girls at the Lewis and Clark Exposition.* A

*The Lewis and Clark Exposition was a fair held in Portland in 1905 to commemorate the explorations of Meriwether Lewis and William Clark. 
Women's Protective Bureau was established in 1909 and Baldwin

headed this new unit. The Bureau was staffed with women who were referred to as "operatives." Their work encompassed all requests which pertained to the welfare or safety of girls. The operatives investigated crimes by girls, supervised the aftercare activities of young women who had been processed through the justice system, and procured short-term employment for those who either appeared to be in trouble or who had been convicted of a crime. $* 56$

To understand the relevance of the work of these early policewomen to the police response to labor radicalism requires that the policewomen be recognized for what they were, namely "child savers."** As child savers, the policewomen were supposed to play a protective and rehabilitative role vis a vis children. The idea was the policewomen could save children from the criminogenic "evils" associated with the social 1 ife of the "dangerous classes" in the city. Hence, the duties of policewomen included the supervision and enforcement of laws pertaining to dance halls, skating rinks, penny arcades, picture shows, and other gathering places for working class youth.

The Women's Protective Bureau in Portland was no different from police-juvenile units in other cities in the respect that

*Special treatment for young women was not a characteristic that was unique to the Portland Police Department. Girls bore a disproportionate share of the burden of juvenile justice in other cities as well during the Progressive era. For an historical inquiry into the practice of sexual discrimination against female juvenile delinquents, see Steven Schlossman and Stephanie Wallach, "The Crime of Precocious Sexuality: Female Juvenile Delinquency in the Progressive Era," Harvard Educational Review, 48 (February, 1978), pp. 65-94.

**For an historical account of the role of the so-called "child savers" in the development of the juvenile court, see Anthony Platt, The Child Savers: The Invention of Delinquency, 2nd Ed. (Chicago: University of Chicago Press, 1977). 
the Bureau exerted a wide span of control over the above-listed areas of the social life of working class youth. While the exact extent to which this control helped or hindered the youth supervised by the women operatives is not known, it would seem that at best the work of Baldwin's Protective Bureau may have had a minimal impact upon the lives of working class youth in view of the modest success of even the most high-powered police juvenile programs in the 1970s. At worst the Bureau's "protective" activities may have reduced the chances of working class youth for participation in the labor market, in educational institutions, and other vital areas of life.* In the final analysis both of these outcomes would have served the same end, namely the perpetuation of a system in which the working class was in a subordinate position to other social classes. In addition to controlling the social life of working class youth, the operatives dominated the process through which juveniles were channeled through the justice system. Since the policewomen ostensibly were there to "help" rather than to punish youth who became enveloped in "unwholesome" circumstances, it followed that they exercised a considerable amount of discretion in handling a child's case. Decisions pertaining to arrest, referral, institutionalization, and other steps in official processing of a case tended to be governed by informal standards such as past experience and "maternal instincts" rather than formal constitutional protections. 67

*The negative effects of the juvenile justice system upon youth are described by Edwin Schur in Radical Non-Intervention: Rethinking the Delinquency Problem (Englewood Cliffs, N.J.: Prentice-Ha11, 1973). 
Lola Baldwin and the operatives in the Women's Protective Bureau dispensed justice to juveniles in accordance with the abovedescribed principles. The merits and methods of Baldwin's work went almost unchallenged for the entirety of her career. During her years of service she was accorded many honors for her contributions to both the fields of law enforcement and corrections.* Perhaps the only time that Baldwin's performance as a juvenile specialist was publically criticized came in 1913, a time of labor and political unrest.

Throughout the year of 1913 the Portland News received complaints about her work. The first complaint to be printed was authored by Jean Bennet, a free speech fighter. Mrs. Bennett became interested in the case of Lillian Larkin, a working class girl and one of Baldwin's "charges," after Bennett had met Larkin in the Portland jai1 (where Bennett and other agitators were confined for street speaking). Bennett criticized Baldwin's handling of the Larkin case in an "open letter" to the Portland community. Portions of this letter have been excerpted from the newspaper and are presented here in order to show the details of Bennett's criticism of Baldwin.

An 18-year old girl by the name of Lillian Larkin was sentenced to 30 days in jail, in Vancouver, Washington. After serving 15 days she was parolled on good behavior and told to go to Lola Baldwin of Portland, and that she would find work for her till she could earn enough money to go to Spokane to her mother, who is seriously $i 11$ there.

*Baldwin was a special agent (i.e., counsel) to seven governors of Oregon as well as a western representative to the national committee on prisons and prison labor. ${ }^{68}$ 
Instead of Mrs. Baldwin getting her work, she has sentenced her to three years, either in a "home" (where they operate a laundry by using convict labor, from $8 \mathrm{a} . \mathrm{m}$. to $5: 30 \mathrm{p.m}$. and where these frail little girls are forced to wash and iron for their food only) or the state institution at Salem...

- . This mere child is denied an attorney [and has] absolutely no redress. She was sjimply railroaded, tried and sentenced by one lone woman.

Seeking to right this alleged miscarriage of social justice, Bennett and the I.W.W. organized a move to obtain the release of Lillian Larkin from the Oregon State Industrial School.* Bennett, representatives of the I.W.W., and Larkin's mother were granted a hearing by the Oregon State Board of Control which was the official body that was responsible for the Industrial School. In a boisterous meeting on November 21, 1913 the fight for Larkin's release developed into an effort by Bennett to discredit Baldwin, who at the time was both the Superintendnet of the police juvenile unit in the Portland Police Department and a member of the advisory board of the Industrial School. Bennett again charged that Baldwin had "railroaded" the girl to the institution and this time she inferred that Baldwin had certain conflicts of interest. Bennett suggested that Baldwin was referring girls in her official capacity as a policewoman to rooming houses and homes which Baldwin either owned or in which she had some other type of interest. The juvenile specialist denied all of these accusations in her own testimony. 70

*The Oregon State Industrial School was a correctional facility for girls in Salem, Oregon. Convicted female criminals as well as non-criminals attended the "school" which stressed the importance of hard work and discipline. 
In spite of the serious nature of the charges introduced by Bennett and the I.W.W., the Board of Control refused to pardon or parole the girl. The board justified its decision on the grounds that the "evidence" showed that the girl was "romantically inclined," had "an inclination for pilfering," and suffered from "a craze for soldiers." 71 At the close of the hearing, Bennett stated that the I.W.H. and herself would try to secure Larkin's freedom through an appeal to the courts.

Three days later Lillian Larkin was released from the Industrial School in a mysterious turn of events. The first was that the truth about the Larkin case was somehow revealed to Bennett and the I.W.W. They discovered that Larkin was "vagged" by the police when she initially arrived in Portland from Vancouver, Washington. The arresting officer then had turned her over to Baldwin for protection; Baldwin, in turn, had sent Larkin directly to the Industrial School for the purpose of detention. ${ }^{72}$ Bennett and the I.W.W., armed with this information, proceeded to post a bail bond of $\$ 3,000$ for Larkin's release several days after the Board of Control hearing. Upon receipt of the bail money, the Board of Control officially discharged Larkin from the custody of the state of Oregon on November $24,1913 .{ }^{73}$ It appears that the Portland authorities also a?so dropped the case since there are no records of other hearings, trials, or incarcerations for Lillian Larkin.

Lola Baldwin remained "under fire" from Bennett and the I.W.W. for the remainder of the year. A cormittee of ten women 
presented the following petition, signed by several thousand citizens, to Mayor Albee in December of 1913:

To Mayor Albee: We the citizens of Portland, state of Oregon do hereby demand the immediate removal from office of Mrs. Lola Baldwin, who has charge of the Municipal Welfare of Public Safety for Young Girls.

Our reasons for wanting her removal from office are: She is utterly heartless and cold b?ooded and not a fit person to be judge of human flesh and blood. She makes no attempt whatever to secure work for these girls, but railroads them to some institution as the easiest way out. She has never been known to make one kind remark, but instead every word she utters makes these giris despise her.

We feel that a motherly person would have a tendency to make the girls better instead of worse. $\star 74$

The petition fell on deaf ears in the Albee administration. Consequent1y, Bennett and the I.W.W. determined that this was one "windmill" that they would not continue to tilt at, thus terminating their short-lived crusade against Baldwin.

*It is interesting to note that the radical reformers in 1913 seem to have shared the stereotypical sex role notions of Baidwin and other more moderate reformers in the same era. 


\section{REFERENCES--CHAPTER $V$}

1. Oregonian, December 1, 1911, p. 11.

2. E. Kimbark MacColl, The Shaping of a City, Business and Politics in Portland, Oregon 1885 to 1915 (Portland: The Georgian Press Company, 1976), p. 358 .

3. Ibid., p. 410 .

4. Oregonian, March 3, 1912, p. 15.

5. News, !larch 16, 1912, p. 1.

6. News, March 21, 1912, p. 1.

7. News, March 28, 1912, p. 4.

8. News, March 21, 1912, p. 1.

9. News, July 1, 1913, p. 1.

10. Oregon Journal, June 27,1913, p. 1; News, June 27,1913, p. 1.

11. News, August 7,1913, p. 1.

12. News, June 28,1913, p. 1.

13. Ibid.

14. Ibid.

15. News, Ju1y 1, 1913, p. 6.

16. News, JuTy 1,1913, p. 1.

17. Ibid.

18. MacColl, op. cit., p. 446.

19. Stewart Holbrook, "Some Notes on an 01d School Radical," The Cal1 Number (Fal1, 1958), pp. 4-7.

20. Oregon Journal, July 16, 1913, p. 2.

21. News, JuTy 2, 1913, p. 1. 
22. Edwin O'Hara, A Living Hage By Legislation: The Oregon Experience (Salem, Ore.: State Printing Company, 1916).

23. Edwin V. O'Hara, "Welfare Legislation for Women and Minors," in Report of the Social Survey Committee of the Consumer's Leaque of Oregon (Portland: Keystone Press, 1912).

24. Ibid., p. 5.

25. Ibid.

26. Ibid.

27. Ibid.

28. Ibid.

29. Oregon Journal, August $8,1913, \mathrm{pp} .1,4$.

30. Evening Telegram, July 3, 1913, p. 10; Oregon Journal, November, 1932, p. 2; Portl and City Directory (Portland: R. L. Polk and Co., Inc., 1913).

31. Evening Telegram, op. cit.

32. Ibid.

33. News, July 4,1913, p. 1.

34. News, JuTy 4,1913, p. 1.

35. Oregonian, July 9, 1913, p. 10.

36. News, July 9, 1913, p. 1.

37. Hews, Ju1y 10, 1913, p. 1.

38. News, July 14, 1913, p. 1.

39. Ibid.

40. News, July 15, 1913, p. 1.

41. Sandra Kosokoff, "The Radicalization of Marie Equi," unpublished manuscript (Portland: Oregon Historical Society, 1971), p. 8.

42. Oregon Journal, July 17, 1913, p. 14.

43. Oregonian, July 17, 1913, p. 14.

44. Oregon Journal, Ju1y 16, 1913, p. 7. 
45. Evening Telegram, July 16, 1913, p. 1.

46. Oregon Journal, JuTy 17, 1913, p. 1.

47. News, July 17, 1913, p. 1.

48. Rodney Stark, Police Riots (Belmont, Calif.: Wadsworth Publishing Company, 1972), p. 17.

49. News, July 18, 1913, p. 1.

50. Ibid.

51. Oregonian, July 18, 1913, pp. 1, 5.

52. Oregon Journal, July 18, 1913, p. 6.

53. Oregonian, July 18, 1913, p. 5.

54. News, July 21,1913, p. 1.

55. Oregon Journal, July 20,1913, p. 1.

56. News, July 19, 1913, p. 1.

57. News, July 21, 1913, p. 1.

58. Portland Police Detective Notebooks, Volume 30, 1913, p. 82.

59. News, July 21,1913, p. 1.

60. Ibid., August 28, 1913, p. 2.; November 5, 1913, p. 1.

61. News, August 1, 1913, p. 1.

62. News, January 17,1914, p. 1.

63, News, October 29, 1913, p. 1.

64. Ibid.

65. News, November 5,1913, p. 1.

66. Letter from Lola Baldwin, Superintendent of Women's Protective Bureau to Chief of Police E. A. Slover (Portland: Police Correspondence Files, 1912); Women's Protective Division Reports in llayor's Message and Annual Reports (Portland, 1913; 1914).

67. Dennis E. Hoffman and Gary R. Perlstein, "A Social History of Police Work With Juveniles," LEA Journal (to be published, 1979). 
68. Oregonian, June 25, 195\%, pp. 10, 14.

69. News, November 1, 1913, p. 1.

70. Oregon Journal, November 22,1913, p. 1.

71. Ibid.

72. News, November 25,1913, p. 1.

73. Oregon State Board of Control, Minutes, RGC9 Session 76A-39, Item 3 (Salem, Ore.: Board of ControT, 1913, 1969), p. 141 .

74. News, December 15, 1913, p. 1. 


\section{CHAPTER VI}

\section{POLICE REGULATION OF THE UNEMPLOYED: \\ AN INTERLUDE BETWEEN INDUSTRIAL \\ SKIRMISHES AND CLASS \\ CONFRONTATION}

\section{Mobilization of the Unemployed}

After the riots and the free speech fights, there was no respite for the Portland and Seattle police from having to deal with the labor radicals. The economic crisis of 1913-1915 and its accompanying problems of unemployment, poverty, and hunger engendered a great deal of turmoil; as always, the I.W.W. was at the eye of the tornado of unrest and the police were charting and trying to control the I.W.W.'s path.

The police were faced with an entirely new set of problems related to labor radicalism when the I.W.W. began to agitate among the unemployed in 1913. The I.W.H.'s official strategy for organizing the unemployed was as follows:

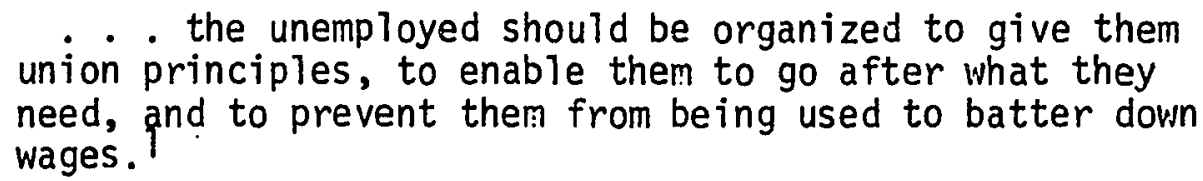

The Portland and Seattle Wobblies implemented this strategy by ?urming "unemployed leagues" (i.e., informa? corporations). These organizations were comprised of unemployed as well as employed and non-union as well as union people. The registered membership in the 
leagues exceeded 3,000 persons in each city by the end of 1913 which meant that about one-third of the approximately 10,000 unemployed persons in each city were organized into the leagues. ${ }^{2}$

The activities of these unemp?oyment leagues reflected the I.W.W.'s direct action principles. The leagues served as sort of "battering rams" that were repeatedly thrust against the municipal governments in Seattle and Portland for the purpose of obtaining public relief for the unemployed. !lore specifically, the leagues petitioned city authorities to provide the unemployed with food, shelter, and jobs.

Both the Portiand and Seattle municipal authorities were unaccustomed to dealing with, let alone negotiating with the unemployed segment of the community. Prior to 1913 the police, for their part, had little to do with law-abiding, unemployed persons. City officials had provided a limited amount of public works employment and local philanthropists had contributed money and other items as personal charity during previous periods of high unemployment. ${ }^{3}$ In turn, unorganized and jobless persons had passiveiy accepted doles of food, clothing, and jobs. This sort of "rich man beggar man" relationship drastically changed once the unemployed became organized into leagues and began to assert themselves in a forceful and aggressive manner in 1913.

At first the Seattle and Portland unemployed leagues utilized petitions and similar institutionally-legitimized techniques in an attempt to peacefully achieve their goals. Neither the city officials in Portland nor those in Seattle responded in a substantial 
way to this strategy of "working within the system." What the unemployed received from the municipal authorities in Portland and Seattle in 1913 was very similar to what poor people have obtained from governments since the passage of the English Poor Law* in 1834-"a shabby pittance." Relief practices in Portland and Seattle in 1913 and early 1914 even reflected the influence of the English Poor Law which was based, in part, on "the principle of less eligibility." According to this notion, relief allowances should be less renumerative and beneficial than regular wages and jobs in the private sector.

The wage scale for persons in public works jobs in Portland was a classic example of the principle of "less eligibility." Portland City Commissioner Witliam L. Brewster, a Tiberal Republican, complained that ". . . the wages paid to the 'bums' are too high." 5 So Brewster used his power as the Commissioner of Public Affairs to lower the wages of single men on public works jobs from $\$ 3.00$ a week to $\$ 1.50$ a week. H. E. Huston, an unemployed person and a member of the Portland Unemployed League, pointed out the farcical nature of Brewster's move in this letter to the editor of News:

A single man living in the very poorest of rooming houses cannot get a place to sieep for less than a dollar a week, which leaves the magnificent sum of 50 cents with which to supply the inner man and clothing....

The same principle was in operation in Seattle where many of the public works jobs were unpaid. ${ }^{7}$ In addition, the Seattle

*The English Poor Law or the Act of 1834 was one of the earliest instances of state involvement in the provision of relief. For an insightful analys is of the English Poor Law, see E. P. Thompson, The llaking of the English Horking Class (New York: Vintage Books, 1966). 
authorities tried to make the terms of employment as undesirable as possible. Seattle Mayor Gill, for example, told 250 unemployed men that the city would provide them with part-time, leaf-raking jobs, if, in return, they would ship their families to the county poor farm. ${ }^{8}$

The "less eligibility" approach to the problem of unemployment failed to appease members of the leagues. The leagues continued to petition the city halls in Portland and Seattle, but the pattern of. governmental response was the same in both cities: meetings between the unemployed and the municipal authorities were held and promises were made about the provision of relief by the authorities, yet the promises were not kept.*

As the trust of the unemployed in the city authorities waned, more direct and confrontational tactics were utilized by the organized unemployed. In Seattle a long line of 200 silent, hungry, unemployed men, standing outside of the chambers of the city council, apparently motivated the council to appropriate $\$ 7,500$ for public works in late December of $1913 .{ }^{9}$ Similarly, in Portland a "mob" of 400 unemployed men swarmed into city hall and compelled the city commissioner to house 1,000 unemployed persons in the Gypsy Tabernacle** and to appropriate $\$ 500$ to purchase blankets and other necessities for the unemployed persons residing at the Tabernacle. ${ }^{10}$

*Al though some part-time public employment was provided in both cities, the number of jobs and the hours of employment fell considerably short of what was pledged by Portland and Seattle authorities.

**The Gypsy Tabernacle was a building where revival meetings were held in Portland. 
Perhaps the high point of the militancy on the part of the unemployed was the march of the "Hungry Hundred" on January 8, 1913. The Hungry Hundred was an army of nearly 2,000 persons who walked from Portland to Salem, Oregon, demanding that the Oregon state and the Portland municipal governments create jobs in the public sector for unemployed persons. Led by Minnie Parkhurst Rimer,* who was the only woman in the Hungry Hundred, the unemployed started their march in downtown Portland; as they strode by the Portland city hall, some of the unemployed persons yelled and jeered loud enough to interrupt a session of the city commissioners. After this bit of mischief, the Hungry Hundred left the city without any interference from the police. 11

Administrative and Statutory Methods of Controlling the Unemployed

It soon became evident to municipal authorities that simply providing a little aid to the unemployed did not stop the protest of the leagues and armies of unemployed. Moreover, the authorities began to be concerned about the I.W.W. element within the ranks of the unemployed in mid-January 1914. Even though the leaders of the Hungry Hundred disclaimed any I.W.W. connections or sympathies, the Portland newspapers and the public suspected that the trek to Salem in quest of jobs was another demonstration engineered by the I.W.W. This suspicion seems to have been justified in view of the fact that the majority of the recruits in the army of unemployed were

*:linnie Parkhurst Rimer and Ed Rimer, her husband, were the "commanders" of the army of unemployed. 
under 25 years of age, single, and foreign born. ${ }^{12}$ The army definitely fit into the Wobbly mold and city officials knew it.

As for the unemployment leagues in Portland and Seattle, the I.W.W. attempted to keep a "low profile" in these organizations. In Portland it was clear that Wobblies were among the early leaders of the unemployed in the Portland Unemployment League, ${ }^{13}$ while it is also known that the Seattle Wobblies were among the founders of the Seattle Unemployment League. Then, too, the radical identities of the Wobblies in the Seattle league were exposed through the vituperative and rhetorical attacks that they made upon Seattle :Mayor Gi11.14

Portland Commissioner Brewster was one of those who felt threatened by the marriage that had been consummated between the unemployed and the I.W.W. Brewster's views on the unemployed were made clear in the following brief statement which he presented at a meeting where relief practices were discussed by city officials and the public:

$$
\begin{aligned}
& \text { them i.e.,[the unemployed out]. . besides it is of } \\
& \text { a great benefit for the community as a whole to get rid } \\
& \text { of them, as it gives the Socialist and the I. W1.W. } \\
& \text { agitators such a large field to work in... } \\
& \text { Concerns about the I.W.W. recruiting among the unemployed gave }
\end{aligned}
$$
impetus to the adoption of another strategy for dealing with the unemployed. Using the police as a new means of sustaining the established order, the authorities began to apply administrative as we 11 as statutory methods against the unemployed. The administrative methods were unofficial and sometimes illegal procedures for managing the unemployed that were at the disposal of the 
municipal authorities. The statutory methods were ways of handling the unemployed that were prescribed in ordinances and laws.*

Three events in Portland involved the utilization of administrative methods. The first event consisted of police interference in a protest march of the unemployed. On January 12, 1914, a second army of unemployed began a march to Salem in quest of jobs and publicity. The army was detained in Portland for a short time when a squad of police rushed the army, pushing and punching its members in a spectacle of police brutality. ${ }^{16}$ In explaining the behavior of the police in this encounter with the unemployed, a Portland patrolman remarked:

orders from 't blame the officers. These men are under
Blame the administration. 17

A second example of administrative methods involved the unemployed who were housed in the Gypsy Tabernacle. City and county police drove 1,200 unemployed men out of the Tabernacle into a driving rain on the night of January $20,1921.18$ The men probably survived the night by sleeping in jails and railroad cars. As for food, many of the men no doubt searched for their supper and breakfast in garbage cans. Again, the city police participated in this rather inhumane fiasco at the behest of city officials. Chief of Police Clark revealed that he had initially rejected a reques $t$ from the Sheriff's office to move the unemployed out of their shelter.

*The terms "administrative methods" and "statutory methods" were first coined by Francis Fox Piven and Richard A. Cloward in Regulating the Poor: The Functions of Public Welfare (New York: Vintage Books, 1971). 
According to Clark, he was forced to act later when Mayor Albee's secretary ordered him to assist the Sheriff in the evacuation of the Tabernacle. ${ }^{19}$ It can be surmised that the impetus for this action came from Mayor Albee and Commissioner Brewster, who earlier had jointly issued a "work or jail" ultimatum to the Tabernacle residents on January 14 th.

In addition to the particular methods used to regulate the poor, a special unit within the Portland Police Department was created in response to the protest of the unemployed. The unit was called a "reserve squad" when it was first introduced on December 10, 1914. This unit came to be known as the "red squad" in 1919.20

Originally, the Portland reserve squad featured a reactive strategy since it remained at police headquarters ready "at a moment's notice to quell any disturbance." Restaurant rushing which typically consisted of unemployed men entering a restaurant, eating a meal, and then informing the owner that the mayor would pay for the meal was cited by Chief of Police Clark as being one type of disturbance for which the reserve squad would be used. The Chief also noted that he expected that the reserve squad would be dealing with restaurant agitators on a large scale "due to the large number of men in town and the scarcity of work."21 Only a few technical details about the reserve squad were released in 1914. Chief Clark revealed that the reserve squad would be ample strength to handle "anything in the nature of a riot." Also, he disclosed 
that the reserve were on duty unti1 10:00 p.m. and that a night reserve would be established in the future. $* 22$

Statutory methods of regulating the unemployed were used by both Portland and Seattle authorities. Insofar as the police were concerned, the power of arrest was an important way of dealing with the unemployed. When the unemployed resorted to the tactic of restaurant rushing, for example, the police agencies in both cities responded by arresting the consumers of "free food" on the charge of "disorderly conduct." 23

The police also arrested persons for "disorderly conduct" in situations where they perceived that the civil order was being disrupted or disturbed. A bizarre incident that occurred in Portland on December 29, 1913 exemplifies this use of statutory methods. Early in the day, a woman who gave the name of Dr. Marie Equi**

* Special details and units, similar to Portland's reserve squad in structure, existed in the Seattle Police Department prior to 1914 , but Seattle radicals had to wait several years for their own red squad. As to the question of why the Portland police formed a quasi-red squad before the Seattle police, two conjectural points might be considered. First, the level of unrest, as indicated by newspaper reports of restaurant rushing, demonstrators and protest marches, seems to have been higher in Portland than in Seattle in 1913-1915. It may be that higher levels of unrest call forth more extreme structural changes in police organizations. Second, a greater concern for structural reform among Portland authorities as compared to Seattle authorities may have been responsible for the earlier introduction of the quasi-red squad in Portland. More specifically, Mayor Albee and the other Portland authorities who advocated a commission form of government, with its stress on specialization and expertise, may have been more inclined than the Seattle authorities to support specialization in the police and other city departments.

**With regard to the possible role of the real Dr. Equi in the prank, leaders of the unemployed said that they did not think that she was the one who had sent the invitation over the phone. However, Julia Godman Ruutilla, a labor radical herself and one of the late Dr. Equi's close friends, stated that she would have "to take the fift' amendment" when she was asked whether or not such a move was part of Equi's repertoire of tactics. 25 
called the hall of the Unemployed League, promising that there would be free meals provided for the unemployed at a local church. Several hundred men then marched to the church in anticipation of eating free food. Upon their arrival there, however, the unemployed were told that dinner at the church had been prepared for members of the Rotary Club rather than for members of the Unemployment League. After the throng turned away from the church, 40 of them went to police headquarters to demand meals. When the police refused to feed them, the leader of the group became noisy and was arrested for "disorderly conduct."24

The enforcement of ordinances prohibiting vagrancy constituted another way in which statutory methods were part of the police response to collective action by the unemployed. Again, both the Portland and Seattle police exercised their power of arrest in charging unemployed persons with the crime of vagrancy. In most instances, the onty crime committed by those arrested for vagrancy was that they were destitute and out of work. The case of Raymond Crosby, who was arrested, charged, and sentenced to jail for vagrancy in 1914 seems to be representative of the vagrancy cases processed through the criminal justice system in Portland. This letter from Crosby's wife, Inez, provides insight into the administration of injustice that occurred as a result of the use of statutory methods.

Dear Judge [Henry E.] McGinn: Little Licia is starving, and I ain't strong enough to work. She's only 3 years old, and it ain't good for little girls like that to starve. I'm starving too, but that don't matter any. You've got my man up there in jail and he'll stay there a long time 
yet if you don't help me. He ain't done nothing wrong at all, and I know he hasn't. Would you take my work for it judge and let him out of jail? Licia needs him badly, and I need him, too.26

The Portland police seem to have placed special emphasis upon making vagrancy arrests to control the unemployed. Table I shows that vagrancy arrests in Portland increased steadily from 1912 through 1915 and then decreased rather sharply in 1916 and 1917. Vagrancy arrests constituted over 13 percent of all arrests in 1912, exactly 14 percent in 1913, almost 15 percent in 1914, and over 16 percent in 1915. Arrests for the same charge decreased after 1915 from more than 16 percent of all arrests in 1915 to slightly more than 10 percent in 1916 and to over 9 percent in 1917.

TABLE I

VAGRANCY ARRESTS MADE BY PORTLAND POLICE, $1912-191727$

\begin{tabular}{|c|c|c|c|c|c|c|}
\hline \multirow[b]{2}{*}{ Year } & \multicolumn{2}{|c|}{ Vagrancy } & \multirow{2}{*}{ Other } & \multirow{2}{*}{$\begin{array}{l}\text { harges } \\
\%\end{array}$} & \multicolumn{2}{|c|}{ Total } \\
\hline & $\mathrm{N}$ & $\%$ & & & $\mathrm{~N}$ & $\%$ \\
\hline & $\begin{array}{r}2,190 \\
2,254 \\
3,319 \\
3,314 \\
1,216 \\
963\end{array}$ & $\begin{array}{r}13.43 \\
14.00 \\
14.96 \\
16.12 \\
10.09 \\
9.70\end{array}$ & $\begin{array}{r}14,121 \\
13,844 \\
18,869 \\
17,245 \\
10,830 \\
8,969\end{array}$ & $\begin{array}{l}86.57 \\
86.00 \\
85.04 \\
83.88 \\
89.91 \\
90.30\end{array}$ & $\begin{array}{r}16,311 \\
16,098 \\
22,188 \\
20,559 \\
12,046 \\
9,932\end{array}$ & $\begin{array}{l}100.00 \\
100.00 \\
100.00 \\
100.00 \\
100.00 \\
100.00\end{array}$ \\
\hline
\end{tabular}

The Seattle police do not seem to have placed as much reliance upon vagrancy arrests as did the Portland police. Statistics from 1912 indicate that only 20 of the 17,078 arrests made by the Seattle police were for vagrancy. 28 In other words, vagrancy arrests accounted for less than two percent of the total number of arrests made in that year. (Data for the years 1913-1917 were not available for use.) 
The difference in the utilization of vagrancy ordinances by the Portland and Seattle police may have been due, in part, to the somewhat different public relief practices in the respective cities. Whereas in Portland, both the "criminal and non-criminal male element" tended to be handled in a similar fashion with a lock-up in jail, 29 in Seattle the unemployed had the opportunity to work two days a week in exchange for free room and board at a public institution. According to Seattle Mayor Gill, the provision of public works even though it was unpaid work, ". . eliminated the vagrant element which we: would have on our hands." 30

Understanding Police Methods of Regulating the Unemployed

The best way to understand administrative methods, such as those used in Portland, is to examine the functions they served for the economic and political order. Piven and Cloward theorized that administrative methods operate so as to enforce low-wage work. They claimed that authorities treat some of the poor in a degrading and punitive manner in order to both deter other unemployed persons from engaging in politics or idleness and to influence unemployed persons to offer themselves to any employer on any terms. 31 Although no data on the intentions of the Portland authorities could be found, Piven and Cloward's functionalist interpretation of administrative methods provides at least a plausible explanation for the harsh and brutish behavior of the Portland police in relation to the Hungry Hundred and the residents of the Tabernacle. 
As for the significance of statutory methods, it is again useful to examine the larger political and economic arrangements in Portland and Seattle. A starting point is the realization that the economies of both cities were dependent upon the lumber industry. 32 Between 1913 and 1916 overproduction was a constant problem in the lumber industry, causing many workers to enter the already large ranks of the unempioyed. The owners logging camps and lumber mills, however, did not complain about the unemployment problems associated with overproduction since the ideal labor force, from their perspective, was one in which many unemployed stood in reserve for work in the lumber industry. With a substantial number of workers held in reserve, the lumbermen could hire employees for relatively low wages and discharge them with relative ease. ${ }^{33}$

From the point of view of the municipal authorities, however, having an "industrial reserve army" was probably viewed as a "necessary evil" under normal circumstances. After a17, the city coffers lost revenue in the short run because of the practice of doling out welfare to the unemployed. Sti 11, some advantages (i.e., higher tax revenues, easier access to loans, etc.) accrued to city governments in the long run as an indirect result of the process of capital accumulation in the lumber industry.

The problem, however, was that an industrial reserve army, especially an army headed by radicals, was mainly a headache for municipal authorities in times of economic crisis. In these hard times the authorities needed more than "stop-gap," emergency welfare reforms to handle the protest of organized, unemployed 
persons. The criminal justice system was one mechanism that was used to control the "surplus" workers. When the criminal justice system was invoked in Seattle and Portland as a partial solution to the problem of unemployment, the authorities, in effect, "criminalized" the surplus labor force by charging the unemployed with vagrancy* and by thus handling them as if they were real criminals. In short, the process of arresting and jailing unemployed persons in Portland and Seattle for the period 1913-1915 constituted a "criminalization of the surplus labor force."

How we 11 did these police methods work in terms of regulating the unemployed? Overal1, it does not appear that police repression of the unemployed effectively accomplished the ends of the authorities in either city. The unemployment leagues and armies were able to force more welfare concessions from the city officials in a shorter period of time than had probably ever been granted before in Portland and Seattle. Then, too, the demise of the movement for public employment in these two cities resulted more from tactical errors made by the I.W.W. than from the actions of the police. 34

In explaining the general ineffectiveness of police methods in handling the radicalized unemployed, it is fitting to borrow a

*The application of vagrancy laws in Portland in the early twentieth century resembled the administration of these same laws in England from the enactment of the first vagrancy statute in 1349 to the present. In both cases the enforcement of vagrancy laws served to protect the interests of powerful social classes and institutions. For an analysis of the origins and uses of vagrancy laws, see William J. Chambliss, "A Sociological Analysis of the Law of Vagrancy," Social Problems, 12 (Summer, 1964), pp. 67-77. 
phrase from R. H. Tawney's study of public relief, repression, and the English poor in the sixteenth century. Tawney observed that: "The whip has no terror for the man who must look for work or starve. "35 


\section{REFERENCES--CHAPTER VI}

1. Fred W. Thompson and Patrick Marfin, The I.W.W.: Its First Seventy Years, 1905-1975 (Chicago: Industrial Workers of the World, 1976), p. 39.

2. Phillip S. Foner, History of the Labor Movement in the United States, Volume IV (New York: International Publishers, 1976), pp. 455-456; News, December 24, 1913, p. 1.

3. News, December 13, 1913, p. 1.

4. Francis Fox Piven and Richard A. Cloward, Regulating the Poor: The Functions of Public Welfare (New York: Vintage Books, 1971), p. 130 .

5. News, January 10,1914, p. 1.

6. News, January 14, 1914, p. 1.

7. Mayor's Message, City of Seattle (Seattle, 1914), p. 19.

8. Solidarity, January 23,1915, p. 1.

9. News, December 29, 1913, p. 5.

10. News, January 3, 1914, p. 1.

11. News, January 8, 1914, p. 1.

12. Oregonian, January 12, 1914, p. 2, cited by Robert Tyler, Rebels of the Woods: The I.W.W. in the Pacific Northwest (Eugene, Ore.: University of Oregon Books, 1967).

13. Arthur Evans Wood, A Study of the Unemployed in Portland, Oregon (Portland: Reed College Social Service Bulletin, 1974), pp. 5; 21.

14. Solidarity, January 23,1915, p. 1.

15. News, January 22, 1914, p. 1.

16. News, January 12, 1914, p. 1.

17. Ibid.

18. News, January 21, 1914, p. 1.

19. Oregon Journal, January 31,1914, p. 5. 
20. Beryl A. Green, untitled autobiography, Volume 4 (1962), p. 57.

21. Oregon Journa 1, December 21, 1914; News, December 10, 1914.

22. Ibid.

23. Oregonian, December 22, 1913, p. 1.; Star, December 1, 1914,

24. Evening Telegram, December 30,1913, p. 1.

25. Interview of Julia G. Ruuttila by Dennis E. Hoffman on July 1 , 1979, Portland, Oregon.

26. News, November 23, 1914, p. 1.

27. Mayor's Message and Annual Reports, City of Portland (Portland, 1912-1917).

28. Annual Report of the Police Department of the City of Seattle (Seatt1e, 1912), p. 10.

29. Mayor's Message and Annual Report, City of Portland (Portland, Oregon 1914), p. 7 .

30. Mayor's Message, City of Seatt7e, op. cit., p. 7.

31. Francis Fox Piven and Richard A. Cloward, Regulating the Poor: The Functions of Public Welfare (New York: Vintage Books, 1971), p. 34 .

32. Joseph Gaston, Portiand, Its History and Builders, Volume I (Portland: 1911), pp. 614-615; Dun and Bradstreet, Inc., Seattle, p. 13.

33. Tyler, op. cit., p. 7.

34. Tyler, op. cit., p. 31.

35. R. H. Tawney, The Agrarian Problem in the Sixteenth Century (New York: Harper and Row, 1967), p. 32. 
CHAPTER VII

FROM LOCAL TO NATIONAL CONTROL OF THE CITY POLICE?

Localism and Police-I.W.W. Encounters in 1916

The year 1916 was a time of testing for the Seattle and Portland police as the struggle of the I.W.W. against the establishment order entered a more virulent phase. At this time, war orders ended economic stagnation and the labor market tightened. "Monster" mass conventions of the I.W.W. were held in Seattle and smaller gatherings of militant workers assembled under the auspices of the I.W.W. in Portland. In both cities the result was the same: the I.W.W.'s aggressive organizing among lumber, maritime, and a miscellanea of other working groups produced a substantial growth in membership in the I.W.W.

Lumbermen and other businessmen in the Pacific Northwest also developed a more organized and unified front in order to protect their interests from the potential onslaught of the labor radicals. Their movement paralleled the intensified organizational activity of the I.W.W. The Washington State Employers Association,* for example, brought lumbermen together to discuss the threat of organized

*The Washington State Employer's Association was made up of West Coast emp? oyers from Washington, Oregon, and California who organized themselves in order to fight the I.W.W. in particular and organized labor in general. 
labor on January 11,1916 in Seattle. ${ }^{1}$ In a similar meeting lumbermen committed theniselves to the "open shop" and founded the Lumbermen's Open Shop Association in Portland. ${ }^{2}$

Police relations with labor radicals in Seattle and Portland retained a localistic cast in 1916 amidst the organization-building movements of the I.W.W. and the lumber interests. Local economic and social, as well as criminal interests continued to infiuence police actions in both communities. In Portland a waterfront strike during the summer of 1916 was the most notable event involving the Wobblies and the police. The International Longshoremen's Association (I.L.A.), several Portland shipping companies, and the I.W.W.*t were the principal parties in this labor dispute. The dispute was handled mainly by county sheriff's deputies; in fact, it was a "special" deputy who became the bane of the troubles in this strike.

The strike situation in brief was this: the I.L.A. strikers picketed the docks, but the employers hired "special" deputy sheriffs to protect non-union men when they passed through the picket 1 ine. Inasmuch as these deputies were paid by Employer's Association, they could not be expected to impartially police the strike. When the special deputies flourished guns. flashed badges, and taunted

*The Lumbermen's Open Shop Association was a group of Portland lumber employers whose main goal was the establishment of "open shop" conditions in Portland.

$\star \star T h e$ I.W.W. Was involved in the capacity of an agitational "third party"; the Wobblies attempted to recruit members of the I.L.A., an A.F.L. affiliate, into the I.W.W. 
the strikers with four-letter expletives on August 4th, it became all too clear whose side the deputies were on. 3

Not only the strikers, but Mayor Albee and Chief of Police Clark registered opposition to this kind of behavior on the part of the special deputies. Albee publicly asserted that it was the "duty of the city to police the waterfront." 4 The mayor also disclosed that he had always been against the deputizing of company employees as special officers. Finally, he announced that Chief Clark had personally informed Mr. McCusker, the secretary of the Employer's Association, that he would persuade the city council to add 25 more men to the police force in exchange for the removal of special deputies from the strike scene. It should be noted that prior to this time the city council had refused to appropriate money to hire additional policemen. However, at the council meeting on the 19th, Albee argued that more patrolmen were needed to police the strike situation on the waterfront. It was only on this representation that the ordinance appropriating money for police salaries was passed by the council. 6

The deployment of these extra officers revealed something about the behavior of the street policemen who had been handling the labor dispute. Since the beginning of the strike, the I.L.A. had complained about inexperienced patrolmen "slugging" and otherwise "roughing up" strikers. Police administrators evidently concurred with the I.L.A.'s allegations because the new men were utilized on quiet beats, thus releasing the older and more experienced officers for duty on the waterfront. 7 
Even after the substitution of official police for special deputies, strike conditions sizzled on the waterfront. The presence of city police at the strike scene became conspicuous in the case of a "scab" who shot and severely injured one of the strikers. The police arrested the scab, charged him with "assault with a deadly weapon" and with "intent to kill," and then placed him in jail. 8 More importantiy, the I.W.W. accused the city police of allowing scabs to carry guns. ${ }^{9}$ The police denied this charge, but an order by a Federal Court judge lent some credence to the I.W.W.'s claims about "gun-toting scabs." In a court order pertaining to I.L.A. picketing, the judge chastized the shipping companies for hiring men and providing them with guns. ${ }^{10}$

The behavior of the city police did not emerge as an issue in the dock strike again. It is worthy of note, however, that police detectives engaged in a considerable amount of surveillance activity at I.W.W. functions at the same time that patrolmen were policing the dock strike. The I.W.W. press reported that "flybulls"* and "stool pigeons"k* were noticeable at a number of organizing and fund raising meetings. ${ }^{11}$ Since only local police were cited as being present at these meetings, it can be assumed that federa? involvement in these endeavors was minimal in 1916.

For the Seattle police, the most significant encounter with labor radicals in 1916 came in the police department's participation detective.

**A stool pigeon is a civilian who acts as an informer for the police. 
in the events surrounding the Everett Massacre.* It was a Seattle police officer who relayed information from two Pinkerton agents to the Snohomish County officials that "a boatload of I.H.W. men and women were leaving for Everett." 12 It was also the Seattle police who handled the survivors of the slaughter that occurred in Everett. The police took nearly 300 uninjured members of the I.W.W. and 3 women organizers into custody, placing them in the Seattle jail. ${ }^{13}$

From the standpoint of local sources of influence on police behavior, the actions of Hiram C. Gill, who was re-elected mayor in 1914, were more significant than those of the police. Gill released a statement to the press in which he exonerated the I.W.W. for the violence in Everett and condemned the Everett authorities on November 8, 1916. His criticism of the Everett officials was trenchant, calling them "imbeciles" and denouncing their inconsistency in the handling of the I.W.W. Furthermore, he directed the carrying of 300 blankets and a supply of tobacco to the I.W.W. prisoners in jai1. 14

The Seattle Chamber of Commerce and some other community influentials took offense at this kind of treatment for the I.W.N. The Chamber and some prominent citizens formed a loose alliance and sought to discipline Gill. They attempted to recall him for a second time and to discredit him by charging him with taking

*The Everett Massacre involved the ambusin and shooting of Wobblies by Snohomish County Sheriff Donald Mc?ae and vigilantes at the docks in Everett, Washington on November 5, 1916. The Wobblies had traveled to Everett from Seattle via boat for a protest meeting. 
bribes from bootleggers. This time, however, the recall effort failed to win the support of the community. 15

Actualiy, the recall and the corruption matters may have served as a guise for a larger issue which aggravated the Chamber of Commerce, namely the conspiracy that conservative businessmen perceived to exist between city politicians, vice operators, and labor radicals. The conspiracy idea consisted of the fact that George F. Vanderveer served as the attorney for Mayor Gill, the I.W.W., and local bootleggers, and the partial truth that Gi11 "supported" the I.W.W. after the Everett tragedy. It was only a small leap of faith for some persons to take the position that vice interests, the I.W.W., and city politics were linked through the personages of Gill and Vanderveer. ${ }^{16}$

This conspiracy notion was logically deficient in that no evidence was ever cited to indicate that the major, the vice proprietors, and I.W.W. leaders ever met or plotted together in order to further their common interests. Whether there was a conspiracy involving the I.W.W. or political rule exclusively by Gill and the Farrell machine, the essential point is that local forces shaped the operation of Seattle's municipal government in 1916.

The Great Lumber Strike of 1917 and the City Police

The localistic hue of policing in 1916 was modified in 1917. The alteration in the traditional local character of the city police was, in part, due to labor unrest. The year 1917 marked the I.W.W.'s 
first real taste of power in the Pacific Northwest. At this time, the I.W.W. focused its organizing efforts on the Northwest timber and mill workers, launching the Lumber Workers' Industrial Union No. 500 in llarch 1917. At its inception the lumber workers' union had a membership of 11,000 persons. 17

Demanding an eight hour day, improved living and working conditions, and increased pay, the I.W.W. set July 17 as the date for a strike in the lumber industry. General unrest in the woods, however, began in early April; by mid-summer almost all of the members of the A.F.L.'s Brotherhood of Timber Workers had walked off their jobs along with the members of the I.W.W.'s Lumber Workers' Union. The strike was almost immediately a success in the logging camps, while only a few scattered mills throughout the Northwest continued operations. 18 The effects of the I.W.W.-led strike were devastating inasmuch as it virtually paralyzed the lumber industry in the Pacific llorthwest. 19

Even before the strike had gathered its full momentum, the major lumber firms in the Pacific Northwest had made definite, cooperative plans about how to cope with the unrest. The lumber industry's top executives determined early that they would refuse to concede the eight-hour day. ${ }^{20}$ In order to maintain the tenhour day, the employers established the Lumbermen's Protective Association. The Weyerhaeuser corporation and about 60 other companies joined the association, pledging to penalize any member which granted the eight-hour day and to threaten firms which refused to assist them. ${ }^{21}$ Additionally, the mill owners, packing 
a fund of $\$ 500,000$, met in rooms of the Industrial Employer's Association Office in Seattle on July 16, 1917 and laid out plans to fight the demand of an eight-hour day. ${ }^{22}$

With the aid of the county police, private police, state officiais, soldiers, and vigilantes, the employers set out to offset the power of the militant lumber workers. At first, the Seattle and Portland police played only a secondary role in the employer's campaign to defeat the I.W.W.-controlled strike. County sheriff's departments, national guard units, special battalions of Spanish American War Veterans, and military personnel carried out the majority of the anti-I.W.W. missions that occurred during the early and midsummer of 1917. These forces conducted mass round-ups of Wobblies, 23 carried out raids on I.W.W. halls, ${ }^{24}$ patrolled vilnerable sections of railroad lines, 25 and guarded mountain passes in anticipation of an imaginery invasion by "hordes of I.W.W.S." 26 These activities took place largely in Washington and to a lesser extent in Oregon lumber camps and rural communities where there was a great deal of unrest in the early phases of the strike.

Both unofficial and quasi-official vigilante groups* were also very active in this first surge against the I.W.W. One vigilante attack upon an I.W.W. hall was foiled by the Seattle

*Groups such as the Minutemen and the Patriotic League operated in Washington with the support of Governor Ernest Lister. The Minutemen consisted of 2,000 to 3,000 men, mostly SpanishAmerican War Veterans, who made arrests, collected intelligence information, interrogated I.W.W. members and other radical suspects, raided I.W.W gathering places, and held prisoners for the authorities. 27 The Patriotic League was composed of patriotic citizens in various Washington cgunties. The League was not used in any major anti-I.W.H. forays. 
police on Saturday evening, June 16th. The unusual raid-prevention course of police action proceeded as follows. On June 13th the I.W.W. learned that the U.S. Marines were planning to wreck the I.W.W. hall. Laying this information before Mayor Gi11, the I.W.W. demanded protection. Although Gill informed the I.W.W. that he doubted the reliability of their source of information, a sufficient number of police were available to repulse the attack when a "Targe number of soldiers and marines" tried to gain entrance to the I.W.W. ha11.29

In the end, however, the Wobblies were the losers. While the raiders were trying to force their way into the I.W.W. headquarters, one of the vigilantes was shot in the leg. As soon as the shot was fired, all 51 Hobblies who were in the hall at the time were placed under arrest by the Seattle police in spite of the fact that the police did not know who fired the shot. Three soldiervigilantes were aiso arrested, and all of those arrested were taken to the city jail. In addition, the police locked up the I.W.W. hall for the next two days. The Wobblies were losers in another sense as well. By halting the I.W.W. meeting in the hall, the vigilantes had at least hindered the planning-organizing-recruiting scheme of the Wobblies.

On a number of other occasions the Seattle police proved to be ineffective in preserving the labor radicals' right to freedom of association. On August 1, for instance, a joint meeting of the Socialist Party and representatives of the American Federation of Labor was broken up by soldiers. The police were able to protect Kate Sadler, a leader of the Socialist Party in Seattle, and the 
rest of the labor radicals at the meeting. ${ }^{30}$ Still, the police dispersed the entire crowd, including the Socialists and the union leaders, thus ending the meeting which was presumably one of the vigilantes' purposes in the first place.

The Portland police became yoked into the anti-I.W.W. campaign when the strike activity heightened in Oregon in August. Just prior to the time that logging operations became hampered along the Columbia River and most of the mills closed in Portland, 31 Mayor George L. Baker proclaimed that an "iron hand" would meet the I.W.W. in Portland. At a conference of federal, state, county, and city officials elaborate plans were formulated to squelch any attempt of the I.W.W. to interfere with the operation of the mills, factories, or ship-building plants of the city.

With regard to the police, Chief of Police John Clark stationed six men at the Eastern and Western Lumber Company and tivo men at the Inman-Poulsen mi1?; other mills were protected by one policeman each. A number of officers were also held on reserve at the police station in anticipation of trouble. This left only four officers patrolling beats on the east side and five officers on the west side in Portland. 32

In addition to this reactive strategy, the Portland police commenced an offensive mission against the I.W.W. On the streets of Portland, a police dragnet swept through lodging houses and various I.W.W. gathering points in search of Wobblies. Scores of workers and I.W.W. organizers were arrested and charged with petty 
offenses by the city police. Portland police even dredged up that "old chestnut," the vagrancy law, as one means of railroading men to the Portland rockpile. $* 33$ "Peddling handbills (urging mill workers to strike) without a 1icense" 34 and "using profane language" 35 were two of the other charges frequently employed by the police for arresting Wobblies.

From the authorities' point of view, one of the negative aspects of this particular dragnet was that non-union as well as union workers were arrested; the experience of being arrested and thrown in jail may have antagonized some of the non-union men, perhaps making them more inclined to join the I.W.W. The case of Valentine Adamik, an Austrian mil1 worker, exemplified the indiscriminate character of the police dragnet in 1917. Adamik was found by police in a basement near the Eastern and western Lumber Company's mil1 where 50 men had walked out two days earlier. He ${ }^{\circ}$ was arrested, charged with vagrancy, and ordered to appear in court. Even though he protested to the judge that he was not a striker, but had been laid off because he was sick, the judge ordered the police to hold Adamik until he could prove he was a "steady worker." While it is not known if Adamik joined the I.W.W. later, it was noted in a report of his court hearing that Adamik was angry and displeased with his treatment by the police. ${ }^{36}$

*During the Great Lumber Strike of 1917 the rock quarry at Rocky Butte (which is now the location of the Multnomah County jail) was utilized as a "sub-jail" in order to handle the overflow of I.W.W. prisoners. 
Federal Intervention Into the Policy of the Great Lumber Strike

Labor's solidarity remained intact despite the repressive methods of the Portland plice and other governmental authorities in the Pacific Northwest. What was needed to break the strike, according to the employers and the local patriots in Seattle and Portland as well as the city and state political officials, was federal intervention on a massive scale. The owners of logging, mill, and shipbuilding firms, who were reaping huge profits during the war, communicated this idea to federal officials through local U.S. attorneys who were based in Seattle and Portland. ${ }^{37}$ Other community influentials also called for federal assistance to crush the strike. The Reverend Mark A. Mathews of Seattle's First Presbyterian Church, for example, wrote to Thomas W. Gregory, the U.S. Attorney General:

[the] . . Kerensky overthrow [had been] largely planned, schemed, and executed in the city of Seattle . . if the military authorities had concurrent jurisdiction when the civil authorities broke down, they could arrest these fiends, court martial, and shoot them. ${ }^{38}$

Colonel M. E. Saville, the head of the military police at Camp Lewis, Washington, authored a report on the situation in Seattle which was no doubt taken more seriously by the Wilson administration, than Mathews' letter. Saville wrote that:

.. a vice ring, a pro-German ring, and an I.W.W. ring with interests interwoven and backed by political, financial, and religious elements of great strength were in control in Seattle, and that city was the pivotal point of all I.W.W. activities in the Northwest. 39

The significance of Saville's report is that President Wilson read it and that Hugh Campbell Wallace, a Democratic national committeeman from Washington and a friend of the President's, told 
Wilson that Saville's interpretation of the linkages between Seattle politics, vice, and the I.W.W. was correct. ${ }^{40}$

National and international forces also weighed heavily in the federal government's decision to intervene into local police affairs. For one thing, President Wilson was aware that I.W.W. strikes interfered with wartime lumber production and that as a consequence, the strikes limited the supply of airplanes and ships that could be used to achieve war aims. Northwest bus inessmen hammered away at this fact in their reports to federal authorities. 41

President Wilson's own political ideology is another factor that should not be underestimated. He was committed to the idea that the spread and growth of Bolshevism and revolution had to be prevented in order to preserve the international framework in which the United States capitalist system could develop to its fullest capacity. ${ }^{42}$ With the advent of the Bolshevik Revolution in November of 1917, he resolved to fight against revolution on both the international and the domestic fronts by assisting counter-revolutionary forces. 43

For these reasons on September 6, 1917, the U.S. government took a major step toward trying to exert control over the policing of 7 abor unrest in Seattle and Portland as well as in the rest of the country. llost of the I.W.W. offices and halls of any prominence throughout the United States were raided by U.S. marshals, who were assisted by local police on this date. Orders for the raids came directly from U.S. Attorney General Gregory, the head of the U.S. 
Department of Justice* and a member of President Wilson's Cabinet. The raids in various cities were synchronized so that they all took place at noon; presumably, the purpose of this timing was to prevent any warning from one place to another. 44

The I.W.W. ha17, the district headquarters of the Lumber Workers' No. 500 and No. 700 unions and the office of the Industrial Worker in Seattle were a11 entered and approximatelly the same minute by U.S. officials accompanied by Seattle police. At the I.W.W. hall the police ordered 150 members of the I.W.W. to vacate the hall whi he a search was conducted. !lany papers and other types of property in the hall were seized by federal officials. $\star * 45$

The intricacies of the raid on the office of the Industrial Worker were described in this eye-witness account of C. E. Payne, the editor of the I.W.W. newspaper.

Two police officers entered the Industrial Worker office with the U.S. official close behind them. . . When the policemen were well within the room, and it was seen that there would be no resistance to them, the U.S. official came from behind them and gave the editor a type-written document of several pages and stated that he had come to seize everything in rooms 24,25 , and 40 in the Union Block.

*The Justice Department was not the only federal bureaucracy that tried to suppress labor radicalism at this time. The Immigration Service detained and deported alien Wobblies, the Postai Service denied mailing privileges to the I.W.W., and the War Department's Loyal Legion of Loggers and Lumbermen ( $\left.4 L^{\prime} s\right)$ and Spruce Division increased spruce production, and undercut the I.W.W.'s support among timber workers. The 4 L's was a government-sponsored union that was formed on November 28, 1917. The Spruce Division was a corps of Army officers who acted as recruiters for the $4 \mathrm{~L}$ 's and as military police to harass and otherwise discourage I.W.H. and A.F.L. organizers from recruiting ventures in the lumber camps.

**Three weeks after the raids, the federal government arrested a large number of Wobblies. In the time between the raids and the arrests federal investigators had used confiscated I.W.W. literature in order to prepare cases under the Espionage Act. 
While McDonald [the Secretary of the Seattle I.W.W.] was reading the document and the police officers and the U.S. official began piling letters, pictures, typewriters, office equipment, books and records indiscriminately into boxes to remove to the 8 ffices of the United States

District Attorney...46

There was no mention of the offices of the Industrial Worker in the warrant, but there were several references to Solidarity, the I.W.W. magazine, which was published in another building. ${ }^{47}$ Yet, both offices were indiscriminately raided. From these facts, it is clear that there was little heed given to the Fourth Amendment in this raid. Indeed, it appears that the raid was conducted under one of the broadest search warrants ever issued by the American judiciary. ${ }^{48}$

The raid on the I.W.W. headquarters in Portland followed the same pattern as the raids in Seattle. A U.S. marshal, a force of secret service agents, city police, and deputy sheriffs entered the I.W.W. headquarters, frisked the 100 Wobblies present, searched for seditious literature and firearms, and seized the Wobblies' I.W.W. membership cards. ${ }^{49}$ The Wobblies were ordered to leave the building and then everything with which the I.W.W. was conducting business-account books, library printing presses, letters and office furniture, pictures, and characters--was hauled away in trucks. ${ }^{50}$

After the September 5 th raids, the ties between federal authorities and the municipal authorities in Seattle and Portland became more noticeable. One indication of these connections is that the police departments in both cities assisted federal law enforcement officers in a series of raids. Seattle police detectives 
collaborated with federal officials in a raid on rooms rented by the I.W.W. in a hotel in November of 1917. Six thousand feet of dynamite fuse* and a load of books, membership lists, correspondence and other documents were seized in this raid, although no arrests were made. ${ }^{51}$ A similar raid was conducted on I.W.W. rooms in another hotel several weeks later. Federal agents, assisted by the Seattle police, confiscated a "truckload of literature and documents" in this raid. ${ }^{52}$ Another raid was carried out by U.S. marshals and the Seattle police on December 20, 1917. This time the police arrested six persons and seized mimeographs, typewriters, and other property that was essential to the operation of I.W.W. business. 53

Still another raid was conducted in Seattle on December 21st. Federal and city police boarded the Russian ship, the Shilka, and searched it for a mythical $\$ 100,000$ in gold that was supposedly to be used in defending I.W.W. prisoners and for munitions that were allegedly to be employed in starting a Bolshevik Revolution in the United States. $^{54}$ In point of fact, the Shilka was not carrying anything more explosive than a cargo of licorice root, peas, and beans! 55 Aside from the raids, instances of federal influence over the activities of the Seattle and Portland police are not as easily discerned. Hevertheless, it appears that the tentacles of the federal government protruded into police affairs in other ways. To be specific, the size, organization, and morale of the Portland police department as well as the public's safety from criminal victimization dynami te fuse.

*It was discovered later that the I.W.W. did not own the 
seem to have been affected by changes in the department made as a result of requests by the federal government. Portland Mayor Baker admitted that the size of the police force was increased by 75 men in 1917 in order that the police could perform the work required of them by the federal government. This work involved the protection of shipbuilding plants and the other important war industries in Portland. From the local authorities' point of view, the industries needed to be protected against the "sabotage" of I.W.W. organizers who were seeking to recruit maritime workers as well as the potential sabotage of bona fide pro-German supporters who may have wanted to destroy plants, ships, munitions, and other war-related paraphernalia.

The deployment of policement at the Portland shipyards carried some consequences that apparently were not anticipated by either the city or federal officials. First, patrolmen who guarded the shipyards began to complain about their own low pay and some even deserted their jobs. ${ }^{58}$ A major reason for the discontent among the street policemen was the difference between the $\$ 100$ a month pay of patrolmen and the $\$ 40$ a week pay of common laborers in the shipyards. ${ }^{59}$ second, the attrition in the ranks of patrolmen coupled with the need to utilize large numbers of police at the sites of war industries reduced the police department's capacity to perform law enforcement and service functions. This fact was brought out in a newspaper expose on the police in which it was revealed that every division of the police bureau was working "shorthanded." Many of the beats were reported to be left uncovered or to have been so enlarged that it was impossible for a policeman to patrol them with any degree of effectiveness. 60 
In terms of organizational change, a "war emergency squad" was formed by the Portland police in response to requests from the federal government. According to Mayor Baker, the purpose of the squad was "to make Portland clean for soldiers." ${ }^{61}$ In other words, the squad was supposed to "protect" U.S. soldiers from the "evils of gambling, drinking, and prostitution." 62 The real function of the war emergency squad may have been something quite different from the publicized purpose. There is evidence that many officers assigned to the squad had little conception of their duties. ${ }^{63}$ Moreover, the names of several of the members of this squad show up consistently on the lists of police who participated in the raids on the I.W.W. halls and headquarters in Portland in 1917.

Linkages between the Seattle police and federal authorities were more tenuous and obscure than those in Portland. Still, the federal government emerged in an important police case against local vigilantes, significantly influencing the outcome of the case. A brief digression is necessary to limn the general contours of the relationship between the vigilantes and the federa? authorities in this case. Beginning with the wrecking of the Pigott Printing Concern on January 5,1918 , several vigilante attacks were made on I.W.W. and Socialist newspaper publishing and distributing sites. ${ }^{64}$ The self-appointed, civilian law enforcement officers wreaked a considerable amount of property damage in each attack; no suspects were taken into custody for any of the vigilantes were riding roughshod over the city. Understandably, the citizenry began to complain about a lack of "law and order" in Seattle. When the Seattle 
police arrested two members of the Minutemen on January 12, 1918 on a charge of being the "ringleaders" of the mob that had wrecked the Pigott Printing Concern,* it was clear to the people of Seattle that the police were attempting to regain control over the city. 65

Federal involvement in the handling of the vigilantes came in the form of Major C. P. Stearns' effort to obtain special treatment for the two Minutemen suspects. Stearns convinced the prosecuting attorney that the men were blameless on account of their membership in Stearns' own Spruce Division. Both Stearns and the prosecuting attorney defended the men's actions, asserting that their crimes were motivated by patriotism. 66 When a farce of a trial in a city court ended in the judge freeing the suspects on the ground of their "emotional insanity" (allegedly caused by seditious articles published by the radical press), it was obvious that federal tampering had influenced the verdict. $* \star$

Police transgressions against the civil liberties of labor radicals is another area in which the federal government and the city police had a close relationship. Portland police working in conjunction with federal authorities, for example, concocted an arrangement for keeping I.W.W. members locked-up. The police would arrest a Wobbly on an "open charge," stating that the Wobbly was

*The Pigott Printing Concern was the publishing office for the Industrial Worker and the Seattle Call, a Social ist newspaper.

**ifinutemen agents were assured that they had the United States government and the Jepartment of Justice behind them in their work of ferreting out radical activities, according to Seattle !linuteman Harry S. Hi ison.68 
being "held for investigation" by federal agents. If the evidence in the case did not warrant prosecution under federal laws, the city courts stepped in and convicted the Wobbly on vagrancy or some other public order offense. This practice was exemplified in the case of 26 Wobblies who were arrested in a federal raid on the Portland I.W.W. hal1. After federal authorities determined that there was insufficient evidence to convict the men in federal court, they were handed over to municipal court for trial on public order offenses. 67

The Seattle police had similar relations with the federal authorities and they were equally abusive of the civil liberties of Hobblies. Excesses of police power were evident in a police-I.W.W. encounter that occurred on January 16, 1918. A brief melee of police brutality was ignited when a street policeman arrested two I.W.W. women for selling copies of the Industrial Worker. When the news spread to the I.W.W. hall, two other I.W.W. women and a large number of 1 umberjacks went onto the streets to sell papers. This new group of paper salespersons was met by a platoon of 32 police, who snatched papers from the hands of news agents, tore up the papers, and clubbed Wobblies as well as a non-union man who was wearing a 1iberty bond button. 69 At the end of the fray 27 of the paperdistributing Wobblies were arrested on the charge of "passing out circulars without a license" (i.e., handbills were inside the newspaper), while the two women who were first accosted by the police were held on an "open charge," pending investigation by the U.S. Immigration Service. ${ }^{70}$ 
Police-I.W.W. Contacts in 1918: A Reexamination

This kind of blatent lawlessness on the part of city police upset some authorities in the U.S. Justice Department. When $\mathrm{Cl}$ arence L. Reames was appointed as a special assistant for all warrelated crimes in Seattle, he was assigned the twin responsibilities of annihilating the I.W.W. and "cleaning" up the law enforcement operations in Seattle as weil as Portland. ${ }^{71}$ Reames himself expressed disgust over the lack of concern for even the rudimentary elements of due process in the conduct of police business in Seattle in the spring of 1918.

When I reached Seattle every public officer, federal, state, and municipal, including members of the Fire Department, and all volunteer organizations exercised the privilege of unceremoniously arresting citizens, aliens, and alien enemies and throwing them unceremoniously into jail, where they were booked for investigation by the Department of Justice. 72

Reames' first actions in Seattle were to order the termination of seizures without warrants and to try to induce all police organizations, official or otherwise, to make no arrests without the approval of the Seattle office of the Justice Department or the United States marshal. ${ }^{73}$ Since the city police turned most of the arrested Wobblies over to federal authorities for prosecution, Reames though that this order would cause the police to alter their search, seizure, and arrest practices.

Studying the behavior of 1 aw enforcement personnel in Seattle, historian William Preston posited that Reames thoroughly centralized all anti-radical activities in his office. However, Preston qualified his position, admitting that "lapses" occurred in the implementation 
of Reames' policy. ${ }^{74}$ How tight was the federal government's control over the Seattle and Portland police during the spring and summer of 1918? While it is impossible to conclusively answer this question because of data limitations, it is exceedingly doubtful that federal officials exerted as much control over the city police as Preston implied they did.

There was at least one flaw in Reames' policy. He appears to have assumed that unlawfur local police practices could be halted merely by the withdrawal of federal support in obtaining convictions. Implicit in this line of reasoning is the notion that the police intervene into a situation solely for the purpose of prosecution. Yet, the Seattle and Portland police often took action against the I.W.W. for purposes other than prosecution in 1918.* More important insofar as Friedheim's stance is concerned, is the fact that the Seattle and Portland police continued to engage in many of the same practices after Reames' appointment as they did before the U.S. Justice Department tried to make Reames a sort of law enforcement czar in the Pacific Northwest. The Seattle police, for instance, made numerous arrests of Wobblies along the Seattle waterfront in March $1918 .^{75}$ It was probably not coincidental that some of the I.W.H. leaders, who were arrested on "open charges," were taken into custody at a time when the I.W.W. was organizing waterfront workers into a union. As for the arrested rank-and-file

*Wayne R. La Fave pointed out that police make arrests for purposes other than prosecution in his benchmark study of police decision-making. See La Fave's Arrest: The Decision to Take a Suspect into Custody (Boston: Little, Brown and Company, 1965). 
Wobblies, most of them could not afford bail so they were packed like sardines into the Seattle city jail. ${ }^{76}$ The purpose of the arrests in these cases seems to have been to disrupt the activities of I.W.W. organizers and to incapacitate rank-and-file Wobblies.

Portland police also made arrests for reasons other than prosecution. In April 1918 an I.W.W. organizer was arrested while he was speaking to a crowd and held on an "open charge. " 77 Breaking down the I.W.W.'s mobilization capacity seems to have been the purpose for arresting this Wobbly leader in Portland. The police in Portland also made arrests in order to gather intelligence information about the I.W.W. Wobblies were grilled by police interrogators in some instances while they were held under the guise of being used as witnesses in upcoming cases. 78

Still other purposes for making arrests were evident in the behavior of the Seattle police. Chief of Police Joel Warren led series of raids that were carried out almost exclusively by Seattle city police without the assistance of federal police. The first raid in the series resulted in the arrest and jailing of 213 Wobblies on "open charges." Chief Warren himself stated that the objective of this police action was to assist in the "successful prosecution of the war. "79

Intimidation was introduced as an acknowledged purpose for police actions in the fifth raid of the series in Seattle in June of 1918. Carrying carbine rifles, Seattle policemen under the direction of Chief Warren raided an I.W.W. meeting in the woods near Seattle. One police officer intimated that the heavy 
artillery was necessary for a "moral effect." 80 The fifth raid may have had other purposes as well as intimidation. In view of the fact that this was the fifth different meeting $p l a c e$ raided by the police in as many raids, ${ }^{81}$ it appears that they may have been trying to interfere with the I.W.W.'s routine business operations. Then, too, the arrest of 32 persons in this raid served to incapacitate some of the most radical workingmen in the Seattle shipyards.

To recognize that certain police practices remained intact in spite of federal encroachment into some aspects of policing labor wars is a necessary analytic step in unraveling the subtleties of local resistance to the nationalization of the city police. For a more complete appreciation of the limits of federal control, it is necessary to briefly explore the role of the local political power-holders in shaping police policy.

George L. Baker and 01e Hanson were respectively the mayors of Portland and Seattle for the period under consideration.* Both Baker, in his roles as Mayor and Commissioner of Public Safety, and Hanson, in his position as Mayor, had formal responsibility for the police. Both were "strong" mayors in the sense that they seemed to possess informal as well as formal power in their relations with the police. In a word, both men "directed" the police departments in Portland and Seattle.

It was Baker who set down police policy for dealing with the Wobblies when they extended the Tumber strike into Portland and other

*Baker was the Mayor of Portland from 1917 to Juily 1933, while Hanson served as Mayor from 1918 to August 28, 1919 at which time he resigned from office. 
parts of Oregon. It was also Baker who told Chief of Police N. F. Johnson to "handle these agitators [i.e., Wobblies] in the severest manner possible." 182 Hence, Baker as well as the Portland police were responsible for the illegalities and excesses in the police methods.

0le Hanson exercised as much control over the Seattle police as Baker did over the Portland police. Indeed, the series of raids during the summer of 1918 in Seattle appear to have been ordered by Hanson. Hanson publicly took "credit" for the first raid, announcing that it was part of his campaign promise "to rid the city of I.W.W.'s." 83 Like Baker, Hanson apparently deserved the credit and criticism for police actions vis a vis the Wobblies.

The immoderate police policies toward the Wobblies that were devised by these two mayors between 1917 and 1919 were greatly influenced by the ideological currents of "Americanism" which flowed throughout the United States in the World War I period.* Both Baker and Hanson were convinced that the I.W.W. had planned the Great Lumber Strike of 1917 for the explicit purpose of undermining the nation's war aims. To Baker the Wobblies were "traitors," 84 while to Hanson they were "Red revolutionists. "85 Without question

*According to Mayor Hanson's own four-page definition of Americanism, the term meant "liberty," "self-government, "equality," "democracy," "continuous progress," "Taw," "love of fellow man," "hope," "optimism," "family love and family life," "one wife and one country," "increased production and increased prosperity for all," "strong national government," "protection of private rights and property," "strength," "preparedness and universal training," "morality," "God and good," "truth," "reason," "proof by experience," "success," "equal suffrage," "reward for individual effort," "ful1 and equal justice," "universal and free education," and "human rights." For more of Hanson's thinking on the subject of Americanism see his Americanism Versus Bolshevism (New York: Doubleday, Page, and Company, 1920). 
the wartime patriotism of these two powerful local figures pushed them in the direction of advocating and supporting repressive police methods. While it would be a mistake to completely discount material interests in explaining police behavior in 1918, it does appear that purely economic forces were of secondary importance behind the over-powering presence of the Americanism ideology. This assertion is based on the fact that no evidence was found to support the proposition that the excesses of city police power in 1918 were due to the influence of lumbering or other business interests upon the police. Yet, the fit between the mayor's ideological convictions and the needs of the employing class in the two cities as well as the authorities in the federal government was so nearly perfect that in the final analysis it must be recognized that Americanism, as it was reflected in the police efforts to suppress labor radicalism, assisted the economically dominant class in accomplishing the larger goa 1 of perpetuating the capitalist system. 


\section{REFERENCES--CHAPTER VII}

1. G. N. Skinner, President, Employers' Association of Washington, Statement of January 15, 1916 in Merril1 Ring Company Papers (Seatt?e: University of Washington Library) cited by Melvyn Dubofsky, We Shall Be A17: A History of the I.W.W. (New York: Quadrangle, 1969), p. 337.

2. Letter of E. G. Ames, Manager of the Puget Mil1 Company, to Fred Talbot, lumber employer, Ju1y 18, 1916; letter of Ames to Mark Reed, lumber employer, July 18, 1916, both in Puget Mi11 Company Papers (Seattle: University of Washington Library) cited by Dubofsky, op. cit., p. 337.

3. Oregon Journal, August 5,1916, p. 1.

4. News, JuTy 17, 1916, p. 1.

5. Ibid.

6. Oregon Journal, July 19, 1916, p. 2.

7. News, JuTy 20,1916, p. 1.

8. Industrial Worker, July 22, 1916, p. 1.

9. Ibid.

10. News, Ju1y 29,1916, p. 1.

11. Industrial Worker, June 1y, 1916, p. 1; July 29, 1916, p. 1.

12. Walker C. Smith, The Everett Massacre (Chicago: I.W.W. Publishing Bureau, 1975), p. 85 .

13. Star, November 6,1916, p. 1.

14. Daily Times, November 8, 1916, p. 1.

15. Industrial Worker, March 24, 1917, p. 2.

16. William Preston, Aliens and Dissenters: Federal Suppression of Radicals, 1903-1933 (Cambridge, Mass.: Harvard University Press, 1963), p. 155.

17. Doug Nelson, "The Portland Industrial Workers of the World: Their Politics and Activities, 1917-1924" (Portland: Unpublished Manuscript, 1971), p. 8. 
18. Paul Abramson, The Industrial Workers of the World in the Northwest Lumber Industry (Portland: Bachelor of Arts Thes is, 1952), p. 80 .

19. Dobofsky, op. cit., p. 362.

20. Letter of R. A. Merri11, President of Merrill Ring [Lumber] Company, to Alex Polson, Tumber employer, July 7, 1917 in Merrill Ring Company Papers, cited by Dubofsky, op. cit., p. 363.

21. Ibid.

22. Star, JuTy 16, 1917, p. 1.

23. News, JuTy 13, 1917, p. 1.

24. Oregonian, July 17, 1917, p. 4.

25. Daily Times, July 12, 1917, p. 1.

26. Star, Ju1y 13, 1917, p. 1.

27. Letter of W. A. Blackwood, leader of the Minutemen, to Wesley L. Jones, U.S. Senator, January 30, 1918, Department of Justice File 186701-49-51; letter of Clay Allen, U.S. Attorney, to Thomas W. Gregory, U.S. Attorney Genera1, November 20, 1917, Department of Justice File 9-5-599-1; both cited in Preston, op. cit., p. 155.

28. Spokane Spokesman Review, July 3, 1917, p. 2.

29. Industrial Worker, June 23,1917, p. 1.

30. Industrial Worker, August 1, 1917, p. 2.

31. Evening Telegram, July 31, 1917, p. 1 .

32. Ibid.

33. Industrial Worker, August 25, 1917, p. 4; News, August 1, 1917, p. T.; Evening Telegram, July 31, 1917, p. T.

34. News, August 6, 1917, p. 3.

35. News, August 3,1917, p. 3; News, August 6,1917, p. 3 .

36. News, August 1, 1917, p. 1.

37. Dubofsky, op. cit., p. 380. 
38. Letter of Mark A. Mathews, Reverend of Seattle's First Presbyterian Church to Thomas W. Gregory, U.S. Attorney General, January 29, 1918, Department of Justice File 186701-49-52, cited by Preston, op. cit., p. 153.

39. Report of M. E. Saville, Colonel in U.S. Army, to the Commanding General of the U.S. Army, March 30, 1918, Department of Justice File 186701-49-88, cited by Preston, op. cit., p. 159.

40. Letter of Hugh Campbell Wallace, Democratic National Committeeman, to Woodrow Wils on, U.S. President, December 29, 1917, Department of Justice File 186701-61-1, cited by Preston, op. cit., p. 158.

41. Letter of Alex Polson, lumber employer, to Charles R. Sligh, U.S. Department of Labor official, August 16, 1917, File 33/574 in U.S. Department of Labor Record Group 280 (Washington, D.C.: National Archives); letter of Western Red Cedar Association to Addison T. Smith, U.S. Congressman, July 3, 1917, File 186701-49-2 in U.S. Department of Justice, Record Group 60 (Washington, D.C.: National Archives), cited by Dubofsky, p. 379.

42. Gabriel Kolko, Main Currents in Modern American History (New York: Harper and Row Publishers, 1976), pp. 52-53.

43. Ibid., p. 59.

44. Industrial Worker, September 12, 1917, p. 1.

45. News, September 5,1917, p. 1.

46. Industrial Worker, September 2, 1917, p. 1.

47. Industrial Worker, September 12, 1917, p. 1.

48. Dubofsky, op. cit., p. 406.

49. News, September 5, 1917, p. 1.

50. Evening Telegram, September 5, 1917, p. 1.

51. Daily Times, November 14, 1917, p. 1.

52. Daily Times, November 24,1917, p. 1.

53. Industrial Worker, December 29, 1917, p. 1.

54. Industrial Worker, December 29, 1917, p. 1.

55. Harvey $0^{\prime}$ Connor, Revolution in Seattle: A Memoir (New York: Monthly Review. Press, 1964), p. 103. 
56. News, February 27, 1917, p. 1.

57. Mayor's Message (Portland, 1917), pp. 5-8.

58. News, March 4, 1918, p. 1.

59. Oregon Journal, May 5, 1918, p. 1.

60. Evening Telegram, May 2, 1917, p. 2.

61. News, January 14, 1918, p. 18.

62. Oregon Journal, January 13, 1918, p. 13.

63. Oregon Journal, January 4, 1919, p. 1.

64. Daity Times, January 6, 1918, p. 1; January 7, 1918, p. 1; January 12, 1918, p. 1.

65. Industrial Worker, January 19, 1918, p. 1.

66. Star, January 7, 1918, p. 6.

67. Industrial Worker, March 23, 1918, p. 1.

68. Transcripts of People v. Lloyd [304 I1linois 23 (136 N.E. 505)

(1922) (Springfield, I17.: Remington-Rand microfi 1m, 1945], cited by Robert Friedheim, The Seattl.e General Strike (Seattle: University of Washington Press, 1964), p. 12.

69. Oregonian, August 8,1917, p. 7 , cited by Robert Tyler, Rebels of the Woods: The I.W.W. in the Pacific Northwest (Eugene, Ore.: University of Oregon Books, 1967), p. 148.

70. Industria1 Worker, January 26,1918, p. 1.

71. Preston, op. cit., p. 160.

72. Letter of Clarence L. Reames, U.S. Attorney, to Thomas Gregory, U.S. Attorney General, March 16, 1918, Department of Justice

File 190159-48, cited by Preston, op. cit., pp. 160-161.

73. Preston, op. cit., p. 162.

74. Ibid.

75. Industrial Worker, March 16, 1918, p. 1.

76. Ibid.

77. Industrial Worker, April 27, 1918, p. 2. 
78. Industrial Worker, July 5, 1918, p. 1.

79. Star, May 3, 1918, p. 11.

80. Union-Record, June 17, 1918, p. 2.

81. Star, June 17,1918, p. 10.

82. News, August 1, 1917, p. 1.

83. Star, May 3, 1918, p. 11.

84. Evening Telegram, JuTy 31,1917, p. 1.

85. Ole Hanson, Americanism Versus Bolshevism (New York: Doubleday, Page, and Company, 1920). 


\section{CHAPTER VIII}

\section{POLICING THE SEATTLE GENERAL STRIKE}

The Problem of Defining Labor Radicalism

The Seattle General Strike in 1919 afforded the defenders of corporate capitalism some of their most perilous moments in the twentieth century. The first line of defense for the forces of order in the General Strike was manned by the city police. From the winter of 1918 through the summer of 1919 the Seattle police were deeply immersed in a battle against the labor radicals who sponsored and participated in the General Strike.

In policing the General Strike Seattle law enforcement

officers faced a perplexing situation in which it must have seemed to them that all working persons were radicals. This was because the term "radical" had a very broad application in the context of the Seattle labor movement from 1918-1919. Even members of the local A.F.L. unions in Seattle were regarded as beirig radicals by the national headquarters in $1919.9^{1}$ The concern about radicalism in the Seattle A.F.L. was not without substance in fact. It has been estimated that 95 percent of the rank and file members in A.F.L. unions in Seattle felt that the workers should control the industries instead of the employers. ${ }^{2}$ Moreover, the prevalent sentiment among Seattle A.F.L. union members was that all working persons had a natural relationsiitip toward one another as "class brothers." 3 
From the standpoint of the Seattle police, the ideological diversity within the local A.F.L. labor movement was of critical importance. Three general groupings--the "conservatives," the "radicals," and the "progressives"--were recognized within the Seattle labor movement. The conservatives tended to favor a practical, incremental approach to improving the working person's lot, usually within the confines of the private property system. The second group, the progressives, served as a buffer between the conservatives and the radicals. The progressive's policy stressed organizational solidarity and integration, while reflecting elements of both the conservative and the radical perspectives. As for the radicals, this group of workers demanded rapid and far-reaching changes in the position of labor in society. The radical group itself consisted fo three subgroups: the "freewheeling" radicals with no outside organizational ties; some Wobblies who simultaneously held I.W.W. and A.F.L. cards and participated in the actions of A.F.L. unions; and the "incipient communists" (the Communist Party of the United States was not formed until August-September 1919) who had strong Bolshevik inclinations and who were also active in A.F.L. affairs. ${ }^{4}$

The police also had to cope with the activities of those Wobblies who operated solely as members of the I.W.W. Additionally, the police dealt with a variety of socialist and anarchist groups which often became involved with the labor movement. The situation was made all the more confusing for the police by the fact that many labor radicals had multiple affiliations. For example, a 
large number of persons were members of the A.F.L., the I.W.W., and the Socialist Party at the same time, although the exact number of these types of labor radicals is unknown and cannot be reliably estimated due to the lack of data.

The Seattle Police and the Labor Radicals in the Winter of 1918 Setting aside the somewhat abtruse issue of defining labor radicalism, it is useful to examine police actions before, during, and after the General Strike. This Iongitudinal view allows for an appreciation of how police policy changed in accordance with shifts in the balance of power between labor and capital. Police behavior in the period preceding the General Strike was much the same as police behavior in the first part of 1918. In line with Mayor Hanson's campaign promise to "get rid of the I.W.W.," the Seattle police persisted in their efforts to repress the Wobblies through the winter of 1918.

The milder side of this repression consisted of the suppression of the Wobblies' basic constitutional rights. The Seattle police has a relatively easy task in obstructing the Wobblies' freedom to associate with one another. To bar the I.W.W. from local meeting halls, all the police had to do was apply some pressure to the owners of the halls. Pressure came in the form of police threats to arrest the owners or have their building condemned by city officials. This tactic worked to near perfection as many property owners refused to allow Wobblies to rent halls for meeting purposes. ${ }^{5}$

Limiting the effectiveness of the I.W.W. press called for a considerably greater amount of police effort than did restricting 
the I.W.W.'s associational activity. Street police were ordered to patrol the streets, looking for Wobblies selling I.W.W. literature. To perform this task we11, patrolmen had to be able to distinguish Wobblies and their printed matter from the other persons and literature that circulated on the streets. This was not an ability with which all patrolmen were blessed. On at least one occasion a street policeman arrested a member of an A.F.L. union who was selling the literature of his own union. The man was charged with "peddling I.W.W. papers," but later released when it was discovered that he was not an I.W.W. member.

This tactic of trying to stop the distribution of I.W.W. materials was not uncommon in Seattle. Newsboys were often taken into custody en masse by the Seattle police. In December 1918, for example, Sergeant P. F. Keefe arrested three newsboys and three I.W.W. members in a round-up of persons sel?ing the I.W.W. newspaper. Following these arrests, Chief of Police Warren was asked to explain the reason for suppressing the I.W.W.'s distribution of literature. He stated that the cause of police action against the I.W.W. Was "sedition" by the I.W.W. ${ }^{7}$

Squelching the Wobblies! freedom of speech was an even more onerous task for the police than trying to render the I.W.W. press ineffective. The main problem for the authorities was differentiating between the words and deeds of Wobblies. Mayor Hanson committed a very foolish error in this regard. On the evening of December 23, 1919 the General Secretary of the I.W.W. told the Mayor in a phone call that "the battle is on." Hanson and police officials interpreted 
this to mean that the I.W.W. Was contemplating an attack on police headquarters. Civic officials were so obsessed with this impression of the meaning of the secretary's wrods that a force of police reserves was lined up ready to repel mythical Wobbly marauders on December 24th. The Mayor and a bevy of city officials also were present at police headquarters that night, waiting to witness a battle that never took place. 8

Police methods such as amassing large numbers of reserves, threatening the owners of meeting halls, and arresting newsboys clearly were not sufficient for the purpose of suppressing the Wobblies' freedom of speech. The motor-mouth, Gatling gun-like verbal skills of the Wobblies along with their tactical expertise acquired in free speech fights, made it necessary to use more forceful methods in order to silence them. More harsh methods of repression were used on the participants in an open-air rally on January 12 th. The result was that a peaceful meeting degenerated into a violent, ugly disturbance because of overzealous police action.

The meeting, sponsored by several union locals and the Socialist Party, commenced with speeches supporting the Bolshevik Revolution. Toward the end of the meeting after five men had spoken and a little girl had read a poem, one of the city detectives sneaked out of the crowd and called a police inspector at headquarters. He notified the inspector that "their language is getting too strong." Police Captain Searing was dispatched to the meeting place and ordered by the Chief of Police to use his own judgment 
as to whether the rally should be adjourned. When he arrived at the meeting, Searing announced to the crowd that the meeting was over. As the crowd walked away from the meeting area zild began to form a parade, a wagon with a red flag attached to it drove by. Someone raised the cry: "There she is! There's the only flag!" In a flash, almost everyone in the crowd took off their hats to the emblem of Bolshevism and then the crowd began singing "the Red Flag," an I.W.W. song. ${ }^{10}$ At this point, Walter C. Smith, an I.W.W. agitator, and an editor of the Industrial Worker, gathered part of a throng of five to six thousand persons around him. Observing Smith's success in gaining the crowd's attention, Captain Searing tried to apprehend Smith in order to, in Searing's words, "nip in the bud any furhter demonstration." Before Searing could achieve his objective, he was attacked by the persons who had surrounded Smith. ${ }^{11}$

Searing was saved from serious injury by the arrival of "squad after squad of police," but the heads, arms, shoulders, and shins of many persons in the crowd were not spared from the blackjacks and sticks wielded by both city and military police; many of these police had burst onto the scene from a hiding place in a building nearby the meeting site. ${ }^{12}$ By the end of this orgy of violence, the police had broken up the parade and had arrested 13 persons for "disorderly conduct." The Seattle Minutemen, who had been conducting spy work during the meeting, helped the police in the arrest process by determining who among the participants was the most radical and therefore, the most disorderly. 13 
Several days later the police were again called upon to keep down the Wobblies. This time the event was an outdoor meeting which had been organized to protest the police tactics used at the January 12th rally. In preparation for this second open-air meeting, the police reorganized three shifts in order to have a large number of policemen available "in case of trouble." In addition, dozens of new clubs were distributed among the emergency details in the Seattle Police Department. ${ }^{14}$

Approximately 500 militants and from five to six thousand spectators turned out for the meeting at which speakers called for the resignation of Mayor Hanson and the removal of Chief of Police Warren. Once again, a parade was formed after the speech-making and again the police intervened to stop the parade. However, this time the police, not the protestors, struck the first blows. The militants, who were leading the parade, were set upon by a small army of police, including 14 mounted policemen, 4 auto trucks containing 50 police armed with carbines, and 5 squads of police on foot with night sticks. In addition, the city police were assisted by about 300 citizens who had been sworn in as special police. ${ }^{15}$ Unfortunately, the outcome of this clash of labor radicals and Seattle police is unclear. Newspaper accounts of this event varied from the Times' report of no police violence ${ }^{16}$ to the Post-Intelligencer's ambiguous observation that the crowd was "swept before" the police ${ }^{17}$ to the Star's portrayal of a ful1blown police riot. ${ }^{18}$ Although there is no way to assess the relative merits of each account, it strains the imagination to think that 
the police, given their performances in handling a similar meeting on the 12th, could mobilize such a large body of men, come face to face with the radicals, and not club a few heads.

On the same night as the protest meeting, the Seattle Metal Trades Council* ordered a strike by the men working in the shipyards. $* \star$ The main issue in the strike was the union's demand of an increase in pay for unskilled workers. Skilled mechanics and machinists, who were drawing higher wages than the unskilled workers, joined their less fortunate co-workers in a strike which actually began on January $21,1919.19$

Many of the 35,000 workers who walked out of the shipyards in this strike were extremely radical even in the context of the Seattle labor movement. This was because a large number of Wobblies worked in the shipyards (because it exempted them from fighting the "capitalists' war") and many of these Wobblies also belonged to the metal-trades unions. The radicalism of shipyard workers was also demonstrated by the Metal Trades Council's sponsorship of the Soldiers, Sailors, and Workingmen's Councils. $\star \star \star 20$

*The Seattle Metal Trades Council was composed of representatives from the local metal trades unions in Seattle.

**A7though Seattle labor called upon its fellow unionists in Portland to join the strike, the Portland Metal Trades Council did not comply with the request from the Seattle Metal Trades Council.

$\star \star \star$ The Soldiers, Sailors, and Workingmen's Councils ostensibly were established to provide assistance to soldiers and sailors who had returned from the war. It appears, however, that the Councils were also designed for the purpose of creating ideological divisions within the ranks of military and ex-military personnel. In effect, the Councils were the American edition of the Bolshevik soviets. 
Following the shipyard workers' walkout, a fast turn of events occurred within a span of 13 days. First, the Seattle Central Labor Council* approved a request by the Metal Trades Council for a general strike throughout the city in sympathy with the shipyard workers' strike. Second, the rank and file members of Seattle's local A.F.L. unions voted to support a general strike. Third, a General Strike Committee of 15 persons was appointed to manage the strike.

Gearing Up for the General Strike

The General Strike Committee began planning for the strike on February 2nd. The committee transacted a heavy volume of business in an all-day meeting; its decisions touched upon nearly every aspect of life in Seattle. Such extensive planning was necessary because the strike was not to be merely a shutdown of the city services; instead, workers in different trades made arrangements to provide essential services to the public.

Police protection, for example, was to be furnished by the strikers. In making preparations to police the city, the strike committee had the audacity to announce that a planned increase in the size of the Seattle police force for the strike would be unnecessary since the strike committee had "perfected" plans to do its own policing on behalf of organized labor. Additionally, the committee placed a "voluntary" 8:00 p.m. curfew on the city and

*The Seattle Central Labor Council consisted of representatives from the local A.F.L. unions. The Council was a very powerful force in Seattle politics in 1918-1919. 
publicly warned the strikers not to cause any disturbances that might turn the public away from the side of organized 1abor. ${ }^{22}$

To work out the details of how labor would police the city, the Committee appointed a three-person Law and Order Committee which was headed by Frank A. Rust. Rust, who was the manager of the Labor Temple Association* and reputed to be a "conservative" labor leader, may have been one of the most radical persons to ever undertake the responsibilities of police management. He reportedly told C. B. Fitzgerald, who was a member of the Seattle city council at the time of the General Strike, that:

I am not for revolution now. I am afraid it cannot win, but if I though it could win, I would be for it down the line. 23

Prior to the strike, Rust's most important activity was the recruitment of union men, who had served in the U.S. Army or Navy, to do police work during the strike. These former military men formed a group which came to be known as the War Veteran Guards. ${ }^{24}$

While the General Strike Committee laid plans to provide vital services, city authorities were deeply involved in the process of making their own plans. Mayor Hanson and Chief of Police Warren played the most important roles in designing police policy for the strike. Not surprisingly, Hanson's decisions were partially influenced by his own super-patriotism. From Hanson's patriotic point of view, the shipyard strike and the general strike were part of a larger conspiracy to foment a revolution in Seattle. The

*The Labor Temple Association was a group of persons responsible for the Seattle Labor Temple. The Temple itself was a building dedicated to the service of labor. 
mayor believed that a "strange body of men," "nearly half a hundred," had gathered in a pool hall in the village of Linnton, Oregon and had laid plans to overthrow the U.S. Government. According to Hanson, the "revolutionists" had selected the shipyard strike as the starting point, the general strike as the follow-up move, and the revolution as the "final blow."25 Hanson identified the conspirators as being the members of a "secret soviet." This small minority, in his view, exercised a disproportionate amount of power in the Seattle labor movement. Hanson, who often attended Central Labor Council meetings, made the following observations in regard to the "red" machinations in wielding power inside of the A.F.L. Iabor movement:

The Reds intentionally prolonged union meetings until almost dawn. When the home owner and the family man was forced to go home, they [the Reds] remained and toward morning did exactly as they pleased ... [often passing] revolutionary resolutions. . At eleven p.m. the meeting would be American, at midnight it would be fiftyfifty, while at two in the morning, only the Reds remained, with sometimes a few so-called conservative leaders who were too cowardly to raise their voices in defense of their country. $* 26$

The demands of businessmen and civic notables weighed just as heavily upon Hanson's mind as the alleged plots of mysterious conspirators in 1919. Prior to the strike Seattle businessmen called upon the Mayor to put the entire city under martial law. 27 Powerful men in municipal government, such as C. B. Fitzgerald, also pressured Hanson to take a firm stand against the General Strike. ${ }^{28}$

*The sans culottes used similar tactics to exercise power in the French Sections in the 1790s. For a detailed account of how a militant minority grasped the reins of power and controlled the majority, see Richard Cobb, The Police and the People: French Popular Protest, 1789-1820 (New York: Oxford University Press, 1970). 
Hanson's actual preparations for the Generai Strike proceeded on a gigantic scale. He wired the U.S. Secretary of War, asking him to "stand ready with government troops" in case the "revolutionists" displaced the city authorities from the seats of power; he requested state troops from Governor Ernest Lister; and he threatened to deputize 10,000 citizens as special police. ${ }^{29}$ As a result of his efforts, federal troops were deployed in the following manner: one battalion of the First Infantry was stationed nearby as a reserve; another battalion and a machine gun company was dispatched to an armory, and smaller detachments were ordered to guard strategic points, such as the electrical power-distribution centers. State troops that were sent to Seattle were stationed in another local armory. ${ }^{30}$ As for the civilian or special police hired by the city, Hans on informed a New York Times reporter that: "We organized 1,000 extra policemen, armed with rifles and shotguns, and told them to shoot on sight anyone causing disorder. . . "31

Actually, the plans for the utilization of special police were somewhat more detailed than Hanson made them out to be. Chief of Police Warren planned to appoint special police to patrol residential "beats," freeing the experienced policemen from these beats and allowing them to be prepared to cope with any strike-related emergencies. With this type of deployment, the police hoped to have a "man covering every street block" and to "break up downtown assemb lages." 32

Chief Warren, working behind the scenes, assumed a critical place in the pre-strike planning. Warren's actions, like those of 
other police officers, were affected by his personal, on-the-job experiences. Most of Warren's law enforcement experience prior to becoming Seattle's Chief of Police came in his role of a confrere to Bat Masterson and Wyatt Earp in the frontier days of Spokane Falls, Washington in the late 1800s. Warren has even been described as an "old Indian-outlaw hunter" because of his dealings with various types of frontier characters. ${ }^{33}$

Wily, old Chief Warren may have known how to suppress labor radicals better than any of the other city officials. Warren summarized his thinking on the police response in General Strike in these words: "I figured it out this way. If the I.W.W. have one gun each, we ought to have from three to thirty for each of our officers. " 34

Warren devised a two-pronged "out-gun-em" strategy. First, to minimize the number of guns for the radicals, Warren comandeered raids on pawn shops and hardware stores prior to the strike in Seattle. The Chief claimed that these raids netted all the guns, the powder, and the cartridges that had been scattered "from hell to breakfast. " 35

Second, Warren stockpiled an enormous amount of military weaponry that could be used by the city police to break the strike. He secured machine guns, mounted them on trucks, and enlisted the services of discharged soldiers to man the guns during the strike. ${ }^{36}$ These "machine guns on wheels" were a particularly ominous symbol of Warren's draconian police planning. These weapons were, in point of fact, motor trucks with barricaded sides, consisting of sand bags 
roped to the borders of the truck, with machine guns mounted in the center, allowing for a complete "sweep" of the street. The sand bags were piled high in the front of the truck to protect the driver, while the wagon of the truck was large enough to hold ten men. 37

\section{The General Strike and Police Coercion}

The beginning of the strike itself was low-keyed compared to the hyperactivity of the pre-strike period. Mayor Hanson described the first day of the General Strike this way:

At ten o'clock, February sixth, a strange silence fell over our city of four hundred thousand people. Street car gongs ceased their clamor; newsboys cast their unsold papers into the street; from the doors of mill and factory, store and workshop, streamed sixty-five thousand workmen.

School children with fear in their hearts hurried homeward. The lifestream of a great city stopped. 38

The first major general strike in the United States was thus set in motion by the forces of radical labor. From the outset, the General Strike was basically led by the A.F.L., while the I.W.W. and the Socialist Party also participated in it. The forces of order also swung into action on the first day of the strike. Before nightfall on the 6 th, thousands of business and professional men as well as non-union workers, flocked to the Seattle City Hall to enlist as special police. ${ }^{39}$ Additionaliy, the plans of the Mayor and the Chief of Police were implemented almost immediately by the entire 447-man city police force, more than 1,000 sworn volunteers, and hundreds of county, state, and federal police.

A peculiar added feature of the police response involved a squad of special policemen who guarded Mayor Hanson's office in the 
City Hall building. It was reported that City Hall "swarmed" with special policemen and detectives and that guards were stationed at every door. ${ }^{41}$ While the exact reason for making a fortress out of City Hall is not known, it may be that Hanson was reacting to statements previously made by enthusiastic Wobblies. Perhaps, for instance, the words "let's hang Hanson," which were spouted in his face at one Central Labor Council meeting, had stuck in his mind. With regard to the policing of the city during the strike, the maintenance of order and the apparent cessation of repressive actions against labor radicals were two of the most remarkable aspects of the General Strike. It appears that the city was more orderly during the strike than under ordinary conditions. The police court docket sank from the norm of about 100 cases a day to 32 cases on the first day of the strike, 18 cases on the second, and 30 cases on the next two days combined. None of these cases was in any way related to the strike. 42

What were the reasons for the maintenance of order? Mayor Hanson argued that peace was secured by the amassing of police. "The knew we meant business and they started no trouble," he boasted in one of his public statements. ${ }^{43}$ In other words, Hanson took the position that a tremendous increase in the city, county, state, and federal police in Seattle had a deterrent effect on the strikers' decisions to create disorder and to commit illegal acts. Based on the findings of contemporary studies on the relationship between 
increases in police manpower and crime rates, however, this position must be deemed to be highly questionable.*

A more feasible explanation of the orderliness of the strike is that labor's solidarity and organization served to instill in the strikers a set of "inner controls" which constrained anarchistic and criminogenic inclinations. The individualistic, self-centered orientation of workers inder capitalist relations of production seems to have been replaced by a class-conscious identify that fostered self-discipline on behalf of the collective welfare of organized labor. In otier words, the strikers abstained from behavior that might have been injurious to labor's cause because they were loyal to the co-operative ideals of the General Strike rather than to the "privatism" of the capitalist order.

The effective operations of the 300-man War Veteran's Guard supplemented these social-psychological controls. These men served under the authority of organized labor, not under the authority of the municipal government of Seattle. Interestingly, labor asserted the Mayor Hanson had offered to deputize the War Veteran's Guard, but that the offer was refused by the Executive Committee. ${ }^{44}$ The Committee evidently realized that if the Guard was deputized, it would take orders from the mayor and not from it. 45

*Robert J. O'Connor and Bernard J. Gilman compared the results from seven studies of increases in police manpower and crime. They concluded that while five of the studies showed a very small deterrent effect, limitations in the data used in all seven studies preclude any certainty about the deterrent effects of police manpower on crime rates. See Robert J. O'Connor and Bernard Gilman, "The Police Role in Detering Crime," in James A. Cramer (editor), Preventing Crime (Beverly Hills, Calif.: Sage Publications, 1978), p. 90. 
What did the War Veteran's Guards actually do in order to keep the peace? Working eight-hour shifts both day and night, the labor guards wore white armbands to designate their status. Their crowd dispersal tactics differed drastically from those used by the city police. Carrying no weapons of any sort, the Guard used "moral suasion" instead of force to control large groups of people. The success of this tactic is reflected in the absence of any violence during the strike.

Another notable feature of the General Strike was that the campaign of police repression that had been directed at labor radicals temporarily stalled during the strike. Evidentiy, the police did not dare to interfere with the A.F.L. strike. 46 Still, the city police did initiate some actions against the more radical elements within the labor movement. For example, Walker C. Smith was arrested on the third day of the strike. He was charged with "distributing printed matter with the intent to incite a riot" for his part in the circulation of "Russia Did It," a pamphlet urging shipyard workers to take control over the shipyards.

The quarters of the International Weekly, a left wing newspaper, were raided by the Seattle police on the same day as Smith was taken into custody. Three persons were arrested and held for federal investigation in this raid. Also, the police seized a large quantity of copies of the latest edition of the Weekly along with several thousand copies of the pamphlet "Russia Did It." A police spokesperson explained the raid as being "in pursuance of the police policy to suppress all forms of I.W.W. and Bolshevik li terature. "48 
Despite the arrest of Smith and the police raid upon the International Weekly, there appears to have been some decrease in the level of the repression of the I.W.W. This impression is based upon the seemingly high number of raids, attacks, and other policeinitiated acts in the months of December and January and the near absence of these types of police action at the time of the General Strike. This cannot be conclusively established, however, due to data limitations and to the possibility of a "regression effect."*

If the police were not rounding up Wobblies and other labor radicals during the General Strike, what were they doing? One thing is clear. The Seattle police did not change their allegiance from the authorities' side to the strikers' side. Following the strike Mayor Hanson, who considered himseif to be an expert on the subject of loyalty, gloated that "Seattle has 450 policemen of whom every man is loyal and true... "49 The police, rather than acting on the basis of the class interests they held in common with the strikers, chose to adhere to the orders of the Mayor, the Police Chief, and other police administrators. By virtue of this acquiescence to the established authority relations, the police wound up doing the "dirty work" of the shipping companies and the municipal government. Not only did the police execute the plans formulated by the Mayor and the Chief of Police, they also were key participants in events that hastened the end of the strike.

*If a regression effect were in operation, the abnormally high number of police raids and other police-initiated acts against the I.W.W. prior to the strike would be expected to decrease during the General Strike merely because of the force of statistical probability. 
The distribution of the Seattle Star under armed police guard had an important impact on public opinion about the strike. Whereas before the General Strike the press as well as various community groups seemed to be supportive of the shipyard workers' strike, the public mood turned against the entire Seattle labor movement at about the same time as front-page editorials in the Star urged opposition to the General Strike. The Star's influence on the public during the General Strike was heightened by the fact that it was the only paper to be widely circulated during the first few days of the strike. The front page of the February 7 th issue of the Star, for example, may have had an especially damning effect on the General Strike. It carried a proclamation from Mayor Hanson in which he threatened to forcibly intervene in the strike and implored the citizenry to show their "Americanism." 50 It is conceivable that public sentiment would not have shifted to favor the authorities as swiftly if this issue had not been distributed throughout the city in trucks and cars protected by police armed with machine guns. 51

The police were an important force in the General Strike in a larger sense as well as in regard to the shift of public opinion. Indeed, the tremendous imbalance in the coercive power at the disposal of the city authorities compared to the strikers may have been the deciding factor in ending the General Strike of February 11, 1919. The significance of both the presence of legions of police fortified with arms, and simultaneously the absence of any similar body of labor supporters with the means to forcibly compel 
compliance with labor's wishes cannot be exaggerated in explaining the termination of the strike.

An inspection of the content of Hanson's proclamation on the second day of the strike and of the strikers' reaction to it lends support to this perspective on the end of the strike. The Mayor flaunted the city's police power in the proclamation.

We have fifteen hundred policemen, fifteen hundred regular soldiers from Camp Lewis, and can and will secure, if necessary every soldier in the Northwest to protect $1 \mathrm{ife}$, business, and property. 52

Anna Louise Strong,* a member of the General Strike Committee, made it plain in her memoirs that Hanson's threat to use coercive means to stop the strike weighed heavily on the minds of the strike leaders. Strong offered this analysis of the thinking of the committee during the strike:

All of us were red in the ranks and yellow as leaders. For we lacked all intention of real battle; we expected to drift into power. . . The general strike put into our hands the organized life of the city--all except the guns. We could last only until they started shooting; we were one gigantic bluff. That expert in bluffing, 0 le Hanson, saw this on the second day of the struggle. ${ }^{53}$

Essentially, this description of the interaction between Mayor Hanson and the committee seems to indicate that the repressive power of the State was a definite force in determining the outcome of the General Strike. Care needs to be taken, however, so as not to overstate the importance of the police in the General Strike. Other

*Anna Louise Strong was a feature editor on the staff of the Seattle Union-Record in 1919. She had a middle class background, earning a Ph.D. at the University of Chicago. Strong became radicalized through her work with persons opposed to World War I. 
social forces also contributed to its termination. Especially consequential in this regard was the patriotic and ideological basis of the state as it was exemplified in the anti-strike media campaign of the Seattle Star and in the Mayor's pleas to the Americanism of the public.

Post-Strike Police Repression

No sooner was the strike over than the city and county police arrested 39 men, including 31 I.W.W. members, on February 13, 1919. Twenty-seven of these men were held and prosecuted under Washington's new "criminal anarchy" act.* Most of these arrests were made in conjunction with raids on the I.W.W. headquarters. In one raid the police stationed a plain-clothes detective in the office of the I.W.W. secretary; the undercover officer then arrested Wobblies as they came into the secretary's office to pay their dues. After this "mission" was completed, the police closed down this headquarters as well as the other I.W.W. offices in Seattle. 55

The Socialist Party headquarters (which served as a base of operations for many persons who supported the General Strike) and the Equity Printing Plant (which had printed the leaflet "Russia Did It") were also raided by the city police soon after the General Strike. The police closed down the print shop, later allowing it

* Criminal anarchy was defined in a Washington state law to consist of: "the doctrine that organized government should be overthrown by force or violence or by assassination of the executive officials of the government or by any unlawful means. The advocacy of such doctrine... is a felony." The remainder of the description of this law is contained in Session Laws of the State of Washington, Sixteenth Session, Chapter 174 (January 13, 1919 to March 1919), pp. 518-519. 
to reopen, but placing the plant under 24-hour police surveillance. The police opened the shop in the morning, censored its operations during the day, and locked it up at night in the course of their surveillance activities. 57

Harassing police raids continued through the spring and summer of 1919. The recurring pattern of police-I.H.W. interaction consisted of a raid, closure of the I.W.W. hall, a reopening of the hall by the I.W.W., and then another raid. A slightly new twist was given to this pattern after the police raided and locked up the I.W.W. hall on June 23rd. This time a court order forced the Seattle police to remove the locks from the door of the I.W.W. hall. Mayor Hanson, not one to be outfoxed by the I.W.W., procured an order from the city Health board to close down the hall on the grounds of "unsanitary conditions." 58

Surprisingiy, the labor radicals were not miffed by the return of heavy police repression after the strike. Harvey 0'Connor, the editor of the International Weekly, made this point in discussing the Wobblies' perceptions of the Seattle police.

.. they [the Seattle police] had not perfected the details of the "red squad" operation. Their dragnets were large-meshed and their operations notorious ly clumsy, so much so that the Wobblies referred to them as "town clowns" and the parody on their operations exhibited in Keystone Kop movie comedies excited the resibilities of the general public. 59

While 0 'Connor's point about the post-strike police raids not being as effective as the red squad activities which were to come later in 1919-1920 is valid, it is a mistake to think that being arrested for "criminal anarchy" and taken into custody by the Seattle 
police during the aftermath of the General Strike was a pleasant experience. One instance of police brutality occurred in the course of the raid on February 13,1919 . This brutality was revealed in testimony offered at the James Bruce trial.* The famous I.W.W. attorney George Vanderveer asked Seattle police Sergeant P. F. Keefe if he had seen another officer strike a Wobbly in the jaw during the raid on the 13th. This exchange between Keefe and Vanderveer ensued:

Keefe: $\quad$ They had a little argument.

Vanderveer: Is that what the police call a little argument? The man was not promint enough in obeying the policeman's orders and so he hauled off and

Keefe: struck him in the jaw?
Yes... [but] he didn't hit him as hard as he ought to. 61

Another police encounter with labor radicals that was marred by violence and brutality took place on July 21, 1919. During an outdoor meeting of the Workers, Soldiers, and Sailors Council, several Seattle police attentively listened to various speakers criticize U.S. intervention in Russia. At the end of the meeting, however, what had been a situation of the police simply maintaining their presence was transformed into a small-scale police riot. Just as the meeting adjourned, 24 police, in groups of 6 , same down through the crowd at the meeting and commenced "sapping heads right and left." A short time later, an automobile loaded with police armed with long, baseball-bat-like clubs, appeared on the street.

*James Bruce was one of 27 workers charged with "criminal anarchy." He was tried on May 19, 1919 and acquitted by a jury on June 5,1919 . Charges against the rest of the defendants were dropped after the "not guilty" veridict was rendered in the Bruce case. 60 
This automobile drove onto the sidewalk and with $i$ ts occupants on the running board headed into the crowd, running down everyone who could not get out of the way. The police on the running board hit whomever they could reach as the automobile slashed through the crowd.

The driver of that automobile, patrolman Frank Braillard, recalled the incident this way 60 years later:

And he [Chief of Police Warren] says, "I'm having a hell of a time down on Washington street .. . you take your three men and your car and go down there." I said, "What do you want me to do?" He said, "Break up that riot. I don't care." He was tough too, he was a tough old boy ... I took my ol little Ford, "Lizzie," a Model T. I jumped the sidewalk. I run em all off the sidewalk with the $62^{a r}$. I didn't care if I hit anybody or not...

With one band of police on the streets driving the crowds onto the sidewalks and another group of police in the automobile driving them off again, it is easy to visualize the slaughter that must have taken place. Scores of injured persons, some of them knocked unconscious, were carted away from the riot scene. At least four persons were arrested by the police on the charge of "disturbing the peace" and one person was arrested for "resisting an officer."63

Raiding and rioting against labor radicals was just one aspect of police behavior during the post-strike period. The Seattle police also employed a reactive strategy. On the first day of the trial of James Bruce, for instance, the Seattle police received a supposed tip that 35,000 Wobblies were planning to storm the courthouse. Responding to this tidbit of crime news, the police stationed a body of officers in the corridor entrance to the 
to the courtroom, had a mounted squad in readiness, and held a reserve of over 100 patrolmen and detectives at police headquarters. 64 In light of the fact that no I.W.W. rescue missions took place at the court, this example of reactive strategy might better be termed as "overreacting."

What was the reason for the intensification of police repression? The information filed in the criminal anarchy cases of many of those arrested following the strike stated that the accused had acted:

. . in concert and in pursuance of a common unlawful and felonious purpose and pursuant to a common understanding among themselves did then and there willfully wrongfully, felonious $7 y$, and anarchistically advocate, teach, and advise the duty, necessity, and propriety of overthrowing the organized government of the United States of America, the government of the state of Washington, and the government of the city of Seattle. . .

What is striking about the criminal anarchy cases is that none of the arrested men had any connection with either the Central Labor Council which called the strike or the General Strike Committee which took responsibility for the conduct of the strike. ${ }^{66}$ of the 27 defendants held on the charge of criminal anarchy, 22 were members of the I.W.W. and 5 were members of the Socialisi Party. ${ }^{67}$ How these men, without an iota of control over the strike, could have overthrown the government remains a mystery.

The real leaders of the General Strike apparently were protected from the police by virtue of their established position in the mainstream of the Seattie A.F.L. 1abor movement. Of the 15member Executive Committee of the General Strike Committee, only two persons were viewed as being radicals and they were not members 
of the I.W.W. ${ }^{68}$ No city police action was taken against any of the members of the Executive Committee.* Of those individuals outside the committee who played a prominent role in the strike, only Leon Green was an ayowed radical. Green, who was tabbed by the federal authorities as being a "dyed-in-the-wool Bolshevik," was sought by the Seattle police. A warrant was issued for his arrest on the charge of criminal anarchy, ${ }^{69}$ but the police could trace Green's movements only until February 9th, after which time he disappeared from Seattle. 70

Mayor Hanson definitely wanted to prosecute someone on account of the strike. Hanson devoted three pages in Americanism Versus Bolshevism to caricatures of the leaders of the strike. He then lamented the fact that these leaders were neither arrested nor prosecuted by any authoritative body. 71 As substitutes for the leaders, Hanson apparentiy targeted the Wobblies to be the recipients of official vengeance. To quote Hanson:

We closed up every "Wobbly" hall in town. We didn't have any law to do it with so we used nails. . . We didn't need any more law than we did to stop the red flag. We just stopped it. 72

But why were the Wobblies chosen to be the "scapegoats" of the General Strike? It appears that they received the brunt of the post-strike repression, in part, because of a radical purge that occurred in the Seattle labor movement. Immediately following the strike, the Seattle press demanded that the A.F.L. rid itself

*Unlike the city police, the federal authorities went after the strike leaders, arresting Anna Louise Strong and other editorial staff members of the Union-Record on sedition charges. These charges against Union-Record staff members were later dropped by the government. 
of radicals. ${ }^{73}$ Local A.F.L. officials appeased the local media, issuing public denouncements of radicals. For instance, B. F. Naumann, the chairman of the Executive Strike Committee at the Central Labor Council, declared that: ". . men who get up on this floor [in the Councill and boldly declare that they are revolutiorists will not be tolerated here... ."74

The withdrawal of the A.F.L.'s support for the I.W.W. placed the Wobblies in a position that was similar to the one they occupied prior to the strike--the status of being politically marginal in relation to the mainstream of the labor movement. This marginal status left the Wobblies without a political power base. From the perspective of the authorities, the Wobblies' lack of power meant that they could again be repressed with minimal costs. In short, the Wobblies were probably the politically safest and the most logical scapegoats from the point of view of Mayor Hans on and the other officials. 
1. Robert Friedheim, The Seattle General Strike (Seattle: University of Washington Press, 1964), p. 29.

2. Papers on Industrial Espionage, Report of Agent 106, March 7, 1920 (Seattle: University of Washington Library), cited by Friedheim, op. cit., p. 29.

3. Ibid.

4. Friedheim, op. cit., pp. 37-50.

5. Union Record, December 23, 1918, p. 7.

6. Union Record, December 21, 1918, p. 2.

7. Union Record, December 21, 1918, p. 4.

8. Union Record, January 4, 1919, p. 2.

9. Daity Times, January 13, 1919, p. 1.

10. Daily Times, January 13,1919, p. 1.

11. Ibid.

12. Ole Hanson, Americanism Versus Bolshevism (New York: Doubleday, Page and Company, 1920), p. 30.

13. Friedheim, op. cit., p. 19.

14. Star, January 16,1919, p. 1.

15. Post-Intelligencer, January 17, 1919, p. 1.; Star, January 17, 1919, p. 1.

16. Times, January 17,1919, p. 1.

17. Post-Intelligencer, January 17, 1919, p. 1.

18. Star, January 17,1919, p. 1.

19. Post-Intelligencer, January 22, 1919, p. 1.

20. Freidheim, op. cit., pp. $40 ; 68 ; 12$.

21. Star, February 4, 1919, p. 2. 
22. Ibid; February 6, 1919, p. 2.

23. Hanson, op. cit., p. 42.

24. History Committee of the General Strike Committee, The Seattle General Strike in Root and Branch (ed.), The Rise of Workers Movements (Greenwich, Conn.: Fawcett Publications, Inc., 1975), p. 235 .

25. Hanson, op. cit., pp. 59-61.

26. Ibid., pp. 57-58.

27. Star, February 7, 1919, p. 1.

28. Freidheim, op. cit., p. 118.

29. Hanson, op. cit., p. 82; Star, February 5, 1919, p. 1.

30. Friedheim, op. cit., p. 30.

31. New York Times, February 9, 1919, p. 1.

32. Star, February 6, 1919, p. 2.

33. Paul C. Hedrick, "The I.W.W. and Mayor Hanson," The Unpartizan Review, XII (JuTy-December, 1919), pp. 35, 39.

34. Ibid., p. 43.

35. Ibid.

36. Hanson, op. cit., p. 82.

37. Star, February 7, 1919, p. 1.

38. Hanson, op. cit., p. 84.

39. Hedrick, op. cit., p. 41.

40. Star, February 7, 1919, p. 1.

41. Ibid.

42. History Committee, op. cit., p. 258.

43. Ibid., p. 259.

44. Ibid., p. 262

45. Friedheim, op. cit., p. 126. 
46. Ibid., p. 138.

47. Daily Times, February 9, 1919, p. 1.

48. Ibid.

49. Hanson, op. cit., p. 83.

50. Star, February 7, 1919, p. 1.

51. Friedheim, op. cit., p. 131.

52. Star, February $\%$, $19 i 9$, p. 1.

53. Anna Louise Strong, I Change Worlds (New York: Henry Holt and Company, 1935), p. 8 2.

54. Star, February 14, 1919, p. 1.

55. Ibid.; History Committee, op. cit., p. 269.

56. Star, February 15, 1919, p. 1.

57. Harvey 0'Connor, Revolution in Seattle: A Memoir (New York: Monthly Review Press, 1964), pp. 239-240; History Committee, op. cit., p. 269.

58. Industrial Worker, July 9, 1919, p. 1.; Hanson quoted in John G. Brooks, Labor's Challenge to the Social Order (Port Washington: Kennikat Press, 1971), pp. 364-365.

59. Harvey $O^{\prime}$ Connor, op. cit., p. 147.

60. Industrial Worker, May 24, 1919, p. 1.

61. Industrial Worker, June 11,1919, p. 1.

62. Interview of Frank Braillard, former Seattle police officer by Bruce Rayborn, Portland police officer, Seattle: March 10, 1979.

63. Industrial Worker, July 30,1919, p. 1.

64. Industrial Worker, July 11, 1919, p. 1.

65. Industrial Worker, May 4, 1919, p. 1.

66. History Committee, op. cit., p. 269.

67. Industrial Worker, May 24, 1919, p. 1.

68. Friedheim, op. cit., p. 99. 
69. Star, February 14, 1919, p. 1.

70. Daily Times, February 13, 1919, p. 1; Star. February 14, 1919, p. 1 .

71. Hanson, op. cit., pp. 92-94.

72. Hanson quoted in Brooks, op. cit., p. 365.

73. Friedheim, op. cit., p. 148.

74. Star, February 13, 1919, p. 1. 


\section{CHAPTER IX}

\section{THE "RED" HUNTING MOVEMENT AND RED SQUADS}

Red Hunting as a Social Movement

The response of the Seattle and Portland police to labor radicalism in 1919-1920 consisted of a ruthless searching out and deliberate harrassment of the members of the I.W.W. and every other radical organization that was known to exist in the municipalities of Seattle and Portland. The general aim of police action was to extract the "disloyal," "subversive," and "revolutionary" element from American society. In effect, there was a "witch hunt" in : Seattle and Portland in 1919-1920 and the Wobblies, Socialists, and Communists were treated as though they were witches.

Red hunting was not limited to Seattle and Portland; it was a nationwide social movement comprised of a web of interrelationships between businessmen's interest groups, the government, patriotic societies, and police organizations. 1 The manifest goal of this movement was the defense of the American way of life against its enemies, but its latent goal was the curbing of domestic radicalism. The repressive actions of the Seattle and Portland police in 19191920 are understandable only as part of this elite-sponsored social movement which was mainly conducted on a national level. 
The single most important feature of the setting for the police repression of the so-called "reds" was the international manifestation of radicalism in the form of the Bolshevik Revolution. After the Revolution in Russia, the U.S. government and media expressed extreme hatred and antagonism toward the Bolshevik political party. One of the main reasons for this anti-Bolshevism was a class consciousness on the part of the economic and political leaders in the U.S. Believing the Bolshevik propaganda about a world-wide overthrow of capitalism and the abolition of private property, the U.S. government and business-dominated media perceived that the Bolsheviks were of and for the workers and peasants of Russia.*2 This perception was incongruent with the dominant political and economic interests in the U.S. and their elitest conception of the necessity of inequality. For this reason, it appears that there was no chance of conciliation between the U.S. power holders who were determined to preserve their privileged position and the Bolshevik party which from its propaganda seemed to be hell bent on a "world proletarian revolution."

Domestic class relations on the national level in the U.S., while not as crystallized as international class relations, were still wracked with discord and conflict. After World War I, a more class conscious, more sophisticated group of economic leaders than existed before the war erected an anti-union front that was composed

*While history has shown that this was an incorrect perception on the part of the political and economic leaders of the U.S., this misperception is important because the ways in which the powers that be defined situations in 1919-1920 had real consequences for them as well as for other social classes. 
of welfare capitalism and Americanism. ${ }^{3}$ The employers seem to have understood the benefits and the necessity of making welfare-type accommodations to labor better after the war in view of their postwar amenability to conceding shorter hours and increased wages to workers.

Americanism provided the employers with an offensive weapon that they utilized as the spearhead for a union-busting drive. The employers' basic strategy was to create the impression that labor was "red." This strategy was implemented by organizations that were created to eliminate labor's closed shop in cities where a closed shop situation existed and to destroy unions in cities where open shop conditions al ready prevailed.

Associated Industries and the Waterfront Employer's Association, for example, were two organizations which led the open shop campaign in Seattle in 1919-1920. Roy John Kinnear, a corporate executive and the President of the Seattle-based Associated Industries preached that:

[labor unions had] . . drifted into the control of the radical, the un-American, the charlatan who ... was ready to direct labor into paths leading to extreme conclusions ...

The words of Kinnear and the other leaders of the open shop campaign were apparently heeded by the press as well as the public since the anti-union movement soon became identified with Americanism. In fact, together the ideas of the open shop and the refusal to recognize unions as collective bargaining units became known as the "American Plan" in many cities. 
In Portland, the anti-union movement was usually referred to as the American Plan, although the official name of the anti-union organization in Portland was "The League to Establish Industrial Democracy." Since Portland was already an open shop city in 19191920, the League's activities centered on breaking up existing unions. Elton Watkins, an attorney and a former special agent in the Department of Justice's Secret Service, ${ }^{5}$ directed these activities. By misrepresenting himself as an official of the federal government who held the power to deport aliens and by using other unscrupuĩous tactics of labor espionage, Watkins was able to intimidate foreign-born as well as native-born members of the A.F.L.-affiliated Tailor's Union and Bakery Worker's Union in Portland in 1920. Watkins' actions helped to bring about the eventual destruction of these unions. ${ }^{6}$

The subterfuge of the League for Industrial Democracy and other "front" organizations in the employer's anti-union campaign was in sharp contrast to the highly visible actions taken by the federal government in order to smash labor radicalism and other forms of radicalism. It is very useful to recognize the interdependent relationship that existed between the federal government and the employers in this regard. The close connections between employers and high-ranking governmental officials stemined from at least two sources. First, the interests of political office-holders and employers were logically linked together by virtue of the dependence of both on the political economy of capitalism. The campaign contributions of business interests to politicians, the 
finances to operate the bureaucratic machinery of the state, and even the privileged positions of the elected officials themselves were connected to functioning of the capitalist system. To support the Wobblies, who advocated "worker control" and other radical reforms, must have seemed like a suicidal stance to the political power-wielders in 1919-1920.

Second, the federal government had become very dependent upon the large industrial corporations as a result of the government's heavy reliance upon the factories, the technology, and the money of major industrialists in waging World War I. ${ }^{7}$ Even before the war, President Wilson predicted that:

War means autocracy. The People we have unhorsed will inevitably come into control of the country for we shall be dependent upon the steel, ore, and financial magnates. They will run the nation. 8

Wilson's analysis proved correct, the industrialists knew it, and they utilized their advantageous position to secure the government's support in an effort to undermine the position of labor. President Wilson himself was a key supporter of the anti-union movement even before it was in full swing in 1979. Wilson identified organized labor as being among the "disloyal" groups in the U.S. in an address on June 14, 1917.

Do you not now understand the new intrigue, the intrigue for peace, and why the masters of Germany do not hesitate to use any agency that promises to effect their purpose, the decit of the nations? . . . They are employing liberals in their enterprise. They are using men in Germany and without as their spokesmen

... socialists, the leaders of labor, ...9 
The media provided an additional means through which the economically dominant class could influence the federal government's policy with respect to labor radicalism. The content of the nation's major newspapers helped to establish the anti-union front in $1919-1920 .^{10}$ A perusal of the verbiage used in the reporting of some of the great events involving labor during the period supports this point. On the second day of the Seattle General Strike, for instance, the Chicago Tribune predicted, "it is only a middling step from Petrograd to Seattle." For the six month period following the General Strike it was commonplace for major newspapers to refer to labor strikes as being "crimes against society." 12 Newspapers such as the Wall Street Journal went even further. For example, in the midst of the Boston police strike in September 1919, the Journal screamed that "Lenin and Trotsky are right on their way." 13 A similar tactic of linking organized labor to Boishevism in order to discredit labor was followed by the New York Times, One day after the Centralia tragedy* in November 1919 the Times alleged that there was "proof that Lenin himself had dictated Bolshevik operations in this city... . 14

The major newspapers' attack upon Russian Bolshevism was even more venomous than their bombardment of domestic labor radicals. The New York Times seems to have been the main purveyor of antiBolshevik innuendos and misrepresentations. The Times' distorted

*On Armistice Day 1919 four American Legionnaires in a patriotic parade were shot down by Wobblies when the Legionnaires attempted to raid the I.W.W. hall in Centratia, Washington. 
reporting of the Bolshevik Revolution prompted Walter Lippmann and Charles Merz to conduct a study of the content of the Times' reportage of the Revolution. Their concluding observations underscore the rabid anti-Bolshevism of the New York Times.

The Russian lie is the father of lies. For lie, damned lie, it has been. It was a lie that the people of Russia were calling for military intervention. It was lie that they believed in Kolchak and Denikin. It was a lie that they did not prefer the Soviet government to anything offered them by the Allied generals and the monarchist cliques ...

And because these lies were the base of a policy of lawless invasion, disgraceful intrigue, bloodshed, devastation and famine, they have had to be established by every device known to panic and credulity. 15

Given the coincidence of interests between the economically dominant class and the political leaders as well as the media's pressure upon the political leaders, the federal government's policy toward radicals from late 1917 through the 1920s was almost predictable in advance solely on the basis of material interests and the dominant powers' perceptions about those interests. In terms of the government's actual policy, the Wilson administration decided to crush the I.W.W. in September 1917, ${ }^{16}$ marked the Bolsheviks in the U.S. for suppression in November 1919,17 and targeted the Communists in the U.S. for raids in January 1920.18

As for organized labor, its position vis a vis the economically dominant class was one of retrenchment. Aithough increases in the cost of living and a desire for the institutionalization of the principle of collective bargaining spawned 3,600 strikes in 1919, workers won only a few of these strikes. Then, too, Samuel Gompers 
and other A.F.L. leaders attempted to consolidate their own power through attacking the unorthodox weapons of radical 1abor such as the general strike and through currying the favor of business and government by supporting anti-labor radical measures both during and after the war. 20

While the A.F.L. was retrenching, the I.W.W. was declining in power in 1919-1920. For a variety of reasons the I.W.W. was no longer a presence in the national struggle between the forces of labor and capital.21 The power of the I.W.W. decreased markedily in the Pacific Northwest; when the economic boom of World War I busted in 1919-1920, logging companies, mi $11 \mathrm{~s}$, and shipyards in the Northwest began to employ fewer and fewer workers. ${ }^{22}$ The crushing defeats of the Wobblies and other labor radicals in both the Great Lumber Strike of 1917 and the General Strike in 1919 also contributed to the demise of radical labor in the Pacific Northwest. By the spring of 1920 the last-hired, first-fired Wobblies were largely eliminated as a force in the labor movement in Seattle and Portland.

The Socialist party and the Socialist Labor party, like the I.W.W., were moving in a backward direction after World War I. In Seattle and Portland, both Socialist parties vanished as political factors in late 1919 and early 1920.23 The Socialists' loss of strength was, in part, due to factionalization within the Socialist party. In fact, in 1919 a substantial number of persons left the Socialist party to join the Communist movement. 24 
The Communist movement itself had a national membership of approximately 70,000 persons in 1919.25 The Communist Party and the Communist Labor Party were the two main organizations of the Communist movement in the U.S. The Communists' laborrelated activities mainly consisted of a great deal of propagandizing among immigrants and groups of unskilled and unorganized workers. Despite its efforts to "raise the consciousness" of the American working class, the Communist revolutionary line never mobilized the grass roots support of working men and women in 1919 on a level that was even comparable to the success of the I.W.W. and the Socialist parties in earlier years. 26

Demobilization and Participation in the Red Hunt

The Communists, $7 i$ ke other radicals, were reluctant participants in a one-sided battle in which they assumed a defensive posture. Al though industrialists and political officials were the main aggressors, third parties to the battle actually carried out much of the repression in 1979-1920. These third parties were drawn from both the working and middle classes.

To understand the role of these third parties in the repression of the postwar years, it is first necessary to grasp the meaning of what has been labeled as the "Great Demobilization." The Great Demobilization involved the discharging and disbanding of the resources that had been utilized by the U.S. government to carry on World War I. The historian Frederic L. Paxson described the Great demobilization as follows: 


\begin{abstract}
- demobilization was upon the United States, more completely without foreknowledge than mobilization had been nineteen months before. There are moments in the history of mobilization in which the government of the United States looked Tike a madhouse; but in demobilization there was lacking even the madhouse in which the crazy might be incarcerated. 27
\end{abstract}

Paxton's point was simply that demobilization after the war was largely unplanned and disorganized. In addition, demobilization had a destabilizing effect upon the U.S. economy. Demobilization affected the labor market in a general way, for example, when the men discharged from military service and the workers laid off from jobs in defunct war industries milled around unemployment offices in 1919. 28 Despite the unemployment problems associated with demobilization, large portions of both working and middle classes seem to have fared well and continued to do so throughout 1919.29 The harsh effects of demobilization were borne, for the most part, by the salaried clerks, civic officials, professionals, and the police. The inflation produced by the rapid growth of profits during the war and the rapid economic destabilization had an especially devastating impact on these occupational groups. The wages of workers in these groups kept pace neither with prices nor the income of workers in other occupational groups. Workers in these groups, whose income had either not increased or minimally increased during the war, had a very difficult time balancing a fixed income against the rising cost of living and managing to keep their spirits up in the face of the fact that their standard of living was falling compared to the standard of living of persons in other occupational groups. 30 
The police and other public employees were perhaps the hardest hit by demobilization. In fact, the police and municipal workers in many cities were worse off economically after World War I than at any time since the Civil War. ${ }^{31}$ Salaries of the Portland and Seattle patrolmen, although increasing through gradual increments for the period of 1912 to 1921 , did not increase enough to suit the street police in these cities. ${ }^{32}$ Indeed, low salaries surfaced as an acute problem within the Port?and police department in 1918 when many patrolmen deserted their $\$ 100$ a month jobs and procured higher paying employment in other working class occupations.

Public employees were precluded from much progressive protest about their situation by their lack of organization. ${ }^{34}$ A case in point is the attempt of the Portland police to unionize in 1919. Demanding an increase in salaries and an interchange of day and night shifts, members of the Porti and police force threatened to organize a union as early as the fall of 1917.35 The Portland City Couricil finally took action on the issue of police unionism on April 28, 1919.

On this date, by a vote of four to one the City Council adopted a resolution intended to prevent the police from affiliating with the A.F.L. The resoluticii provided that any police officer joining the proposed union was to be dismissed from this job "for the good of the service." ${ }^{36}$ This resolution was supported by Mayor Baker and the entire council with the exception of one commissioner who cast the only dissenting vote. ${ }^{37}$ since no police union was organized in Portland in 1919-1920, it appears that the resolution served its purpose. 
Workers in these declining occupational groups were not similarily constrained from participation in reactionary collective action. To the contrary, workers in these groups were simulated to conservative political action in order to protect and to defend their eroding material base.* Then too, many workers in these declining occupations may have been inspired to participate in right-wing politics by the Americanism ideology that was rampant throughout the U.S.

Some persons from professional occupations, like Elton Watkins of Portland, were power brokers in organizations which represented a blend of anti-unionism and super-patriotism. Organizations such as the Better America Federation, $\star \star$ the American Defense Society, and the League to Estab1ish Industrial Democracy featured a rather unique division of labor. While corporate interests and individual businessmen kept workers afloat economically by pumping money into the organizations to fight the open shop and to defame the labor movement, 38 the professionals, in turn, facilitated the repressive policies of the dominant economic and political interests by spying on reds and by propagandizing the public on the virtues of 100 percent Americanism and on the dangers of radicalism. ${ }^{39}$

*Samuel $P$. Huntington has made the point that declining social forces are often galvanized into right-wing political action. For a more complete analysis of declining and rising social forces, see Samuel P. Huntington, "Post-Industrial Politics: How Benign Will It Be?" Comparative Politics, 6 (January, 1974), pp. 163-191.

**The Better America Federation, the American Defense Society, and the League to Establish Industrial Democracy are only a few examples of this type of organization. The American Legion and the $\mathrm{Ku} \mathrm{Klux} \mathrm{Klan,} \mathrm{though} \mathrm{not} \mathrm{exclusively} \mathrm{patriotic} \mathrm{organizations} \mathrm{like}$ those listed above, also aided in the anti-labor/anti-radical crusade. 40 
The police were another occupational group whose members participated in the red hunting movement. Federal police were highly visible participants due to their raiding, arresting, incarcerating, and deporting of radicals. Much of this type of activity centered around the "PaImer Raids" of November 7, 1919 and January 2, 1920. While the Palmer Raids themselves were planned by U.S. Attorney General A. Mitchell Palmer, special agents of the U.S. Bureau of Investigation actually performed the repressive acts that comprised a "reign of terror" against domestic radicals.

Working under J. Edgar Hoover, the head of the Justice Department's General Intelligence (anti-radical) Division, these federal police officers arrested many persons illegally, conducted illegal searches and seizures, acted as "agent provocateurs," administered beatings to prisoners, and held many persons incommunicado in filthy, overcrowded jails during the Palmer Raids. ${ }^{41}$ The federal police were usually assisted in their activities by city police.

Red Squads as Social Movement Organizations

At the same time that the federal government was displaying a sustained drive against Wobblies and other radical types, municipal governments were cooperating in the movement to curb radicalism. On the state level, legislatures passed criminal syndicalism, criminal anarchy, and red flag laws.* City police, often operating is special units called red squads, enforced these laws. The purpose of these squads was to watch over, to harrass, and to intimidate left-wing radicals and union organizers. ${ }^{42}$

*Red flag laws prohibited the display of red flags in public. 
Seattle and Portland were two of the cities in which police red squads were formed to do battle with the "reds." As one might suspect, the exact dates on which the red squads were introduced into the Portland and Seattle police agencies are unknown. The creation of a red squad was officially announced to the Portland public in a press release on January $6,1920,43$ while the existence of a red squad was unofficially disclosed to the Seattle public in a news story about a police raid on November $18,1919.44$ These dates, however, are not in accord with other data bearing on the earliest days of red squad activity in Portland and Seattle. The activities of a quasi-red squad in Portland, as indicated earlier, were fairly pronounced from 1914 through World War I. ${ }^{45}$ As for the Seattle red squad, it appears that certain officers within the Seattle police department were assigned the task of handling the cases of Wobblies as early as February 20, 1918. ${ }^{46}$ Given the disparity between the publicly released dates for the inception of red squads and the actual occurrence of somewhat specialized anti-radical activities, it appears that both city police agencies attempted to conceal the real origins of red squads.

When the police wanted it to be known that the red squads were in action, almost a fanfare introduction was given to the new units. Portland Mayor Baker called the creation of the red squad the "most important change made" in the organization of the police department; ${ }^{47}$ the Seattle police as well as the Portland police were conspicuously careful about providing the names of red squad members to the press whenever the squad conducted a raid or made a major 
"pinch" on radicals. The names of Lieutenant Harvey Thatcher and Sergeant P. F. Keefe, the respective heads of the Portland and Seattle red squads, appeared so many times in print from 1919-1920 that they surely must have become household words in residences throughout the Pacific Northwest.

All of the publicity about the "patriotic" activities of the red squad probably served the purpose of maintaining the commitment of Thatcher, Keefe, and the other squad members to the main goal of the red squads which was to ferret out radicals. The incentive of public recognition may have reinforced the values of Americanism which were already deeply held by some members of the red squads.

Harvey Thatcher, a former soldier and a member of the American Legion Post No. 1 in Portland, revealed his personal anti-radical attitudes in this note to Chief of Police Jenkins:

The Communist and other undesirable characters: Since the drive on Communists there has been 97 of them arrested and this move is without doubt the work of Crime Prevention. This type of individual has no regard for our country and any crime that they may be able to commit does not mean anything to them. 48

As an organizational unit within the Seattle and Portland police departments, red squads must be vielved as part of the effort of municipal reformers to overcome the decentralization of the police function. The red squads in each city consisted fo a leader and at least one other full-time member. The permanent red squad members were often assisted by patrolmen on a temporary, part-time basis. Leaders, who were mere lieutenents and sergeants, as well as the patrolmen in red squads took orders only from the top police administrators in Portland and Seattle. 
Portland Chief of Police Leon V. Jenkins, who was appointed by Baker in 1920, revealed in his memoirs that the two members of the Portland red squad worked directly out of his office. ${ }^{49}$ Jenkins also strongly implied that this centralization of police work that had preciously been done by patrolmen working out of the precincts, resulted in "keeping activities of radicals and racketeers down to a minimum. ${ }^{50}$ The Seattle red squad appears to have been afforded a similar position within the police department. This is mainly a surmise based on the fact that the Seattle Chief of Police had an intimate working relationship with the Seattle red squad, occasionally leading the squad on raids.

Sources of Influence on Red Squad Activities

To a large extent, the environment of the red squads determined the actions and practices of squad members. The red hunting movement itslef comprised one segment of this environment, while the other major segment of the environment was the society in which the movement existed. Since the red hunting movement seems to have been directed and supported by the dominant political and economic interests it is useful to explore the red squads' activities vis a vis the specific national, local, and state interests which sponsored the movement.

National political leaders had perhaps the greatest influence upon the functioning of the red squads. The Department of Justice's policy of targeting Bolshevism for special attention in November $1919^{51}$ seems to have largely determined the volume of certain activities 
for the red squads. Seattle's red squad, for example, was more active in raiding and dragnet operations than Portland's red squad in 1919-1920. One explanation of this difference between the two is that the Workers' Union of Soviet Russia* was very active in Seattle, at this time, whereas the Bolshevik element was not nearly as strong in Portland. 52

The influence of the Department of Justice was also manifested in the tactics and procedures utilized by the red squads in both cities. For the most part, red squad members served as "foot soldiers" in the raids on the radicals' secret headquarters** and in the dragnets for specific types of radicals in Portland and Seattle. In a typical raid the red squad would enter a hall or meeting place accompanied by two patrolmen, a special agent of the Bureau of Investigation, and sometimes an inspector from the Immigration Service. Then the red squad would arrest suspects, search the premises, and seize property. Finally, thie red squad would take the suspects to jail where they were held for investigation on open charges and later were interrogated several times by federal authorities. 53 If the federal authorities failed to glean sufficient information to either deport the suspects or prosecute them under the Espionage or Sedition Acts. the suspects were turned over to

*The Workers' Union of Soviet Russia was comprised of Russianborn workers, some of whom may have been agents of the Bolshevik party in Russia.

**By April 1920 the I.W.W. had gone "underground" in Seattle. The I.W.W.'s secret headquarters included hotel rooms, private homes, and various other hiding places. 
the county attorney, who either proceeded against the suspects under the criminal syndicalism, criminal anarchy, and vagrancy läws, or released them from custody. 54

Dragnets tended to be longer in duration and more discriminating in character than raids in 1919-1920. In a dragnet the norma? procedure was to send the red squad and several patrolmen onto the streets for several hours or even several days in search of a particular type of radical. The alleged radicals were arrested and then treated to the same detention in jail, interrogation, and prosecution as the radicals who were taken into custody during a raid. In general, dragnets seem to have been utilized more often in 1919-1920 than in previous periods. The increased use of dragnets may be partially attributable to the fact that the I.W.W. and the other radical organizations were constantly on the move in an attempt to evade the police. These moving targets were probably more difficulty marks for the police than were the stationary radical organizations which existed prior to 1919.

A] though a raild and a dragnet were different procedures for the Seattle and Portland police, the two tactics became intermixed on at least one occasion. With Sergeant P. F. Keefe's red squad leading the way, a small army of federal and municipal police spent the entire night of January 19, 1920 rounding up Russians in Seattle. Three hundred and sixteen Russians were netted by the army of red hunters which included a Commissioner of the Immigration Service, a special agent of the Bureau of Investigation, 14 imnigration inspectors, and 100 city policemen along with the red 
squad. The army raided restaurants, hoteis, and pool rooms in a working class district in Seattle. ${ }^{55}$ When 289 of the 316 suspects were released from custody the next day by immigration authorities, it was evident that this police mission lacked the discriminating characteristic of many of the other dragnets conducted by red squads in 1919-1920. Additionally, the all night collection of police activities on the 19th was considerably longer than the usual 15 to 20 minute raid.

Red squads also held property as well as persons for investigative purposes. Membership lists, address books, and letters were seized and then utilized to track down radicals. 56 Financial records were also taken by the police in order to find out the names of the contributors to various prisoner's defense funds. In addition, thousands of I.W.W. five dollar gold pins were confiscated, presumably in order to sap the financial resources of the I.W.W. 57 Over and above all of this, the police continued their earlier practice of seizing and destroying literature, business supplies, and office equipment in order to disrupt the business operations of radical organizations. 58

The real gems mined by the red squads, however, were neither gold nor dollars. "Discoveries" of sinister plots to overthrow the government, of rival societs, 59 and of secret agreements between the I.W.W. and Lenin ${ }^{60}$ were the most highly prized things seized by the Portland and Seattle red squads. Although it is true that there was a flurry of propaganda and other related activities by members of the Bolshevik party and by workers who sympathized with 
the principles of the Bolshevik Revolution, * the alleged plots and agreements unearthed by the red squads were more like "inventions" than "discoveries."

It is a mistake to cavalierly dismiss these fabricated stories as merely hoaxes for they served a useful purpose for the red squads. By making the radicals appear to be more powerfut and more organized than they really were, the red squads, in effect, ingratiated themselves with the dominant economic and political interests that wanted to see all varieties of radicalism stamped out. That is, it is assumed that the red squad members exploited the local power wielders' concern about "reds" for personal gain and in order to strengthen the organizational domain of the red squads within the Seattle and Portland police departments. **

Apparently, this is precisely what happened with respect to the Portland red squad. Not only did it demonstrate organizational resilience by remaining in existence iong after the I.W.W. excitement had ebbed in the city, but individual members of the red squad also reaped personal gratuities from employers for performing labor espionage activities. Two of the red squad's money-making schemes were revealed in a report on the Portland red squad by the Oregon

*It is a fact, for instance, that the Workers' Union of Soviet Russia, a soviet-like organization, had local representatives in Seattle in 1919. It is also true that about 400 members of the Seattle International Longshoremen's Association (I.L.A.) tried to stop the flow of arms from the port of Seattle to the "white forces" in Siberia in September 1919.61

**J. Edgar Hoover was one of those who was able to parlay the concerns of propertied interests and national political leaders into an increase in personal power and an enlargement of the resource base of the Bureau of Investigation. See Michael R. Belknap, "The Mechanics of Repression: J. Edgar Hoover, the Bureau of Investigation and the Radicals, 1917-1925, Crime and Social Justice, 7 (Spring-Summer, 1977), pp. 49-58. 
Chapter of the National Lawyer's Guild. $* 62$ It is important to recognize that both of these arrangements involved Portland employers exerting direct influence over the activities of the red squad.

The first scheme consisted of the squad providing "labor spies" for private employers. The procedure for hiring police investigators was for the employer to approach the head of the red squad and to request a spy; the spy was then supplied by the red squad but paid by the employer. Under this arrangement those members of the red squads who were also under the hire of businessmen, received their usual salaries from the city of Portland as well as additional money from industrial employers. ${ }^{64}$

Another red squad scheme was to provide employers with information on the political affiliations of the union employees in exchange for monetary contributions to the secret coffers of the red squad. In the process of determining whether or not a person was a "red," squad members used the squad's red files** and based their decisions on personal definitions of what constituted "patriotic Americanism," "radicalism," and "Communism." Although the consequences of this operation are not known, it is suspected that

*Although the report covered the period of 1934-1937, one of the authors of the report claimed that the same schemes discoverefd in 1938 were in operation on an even larger scale in 1919-1920.63 Even if these schemes were not utilized by the red squad until 1934-1937, the proposition that the squad's spectacular "tales" about radicals in 1919-1920 endeared them to the local elites and had the consequences of facilitating the acquisition of resources for individual and organizational aggrandizement would retain its plausibility.

**The red files listed the liberal and radical affiliations of all persons suspected of being radical. 
the branding of union employees as Wobblies or Communists resulted in the firing of many of them by employers. In this respect, the red squad's activities had the appearance of deliberate anti-unionism. ${ }^{65}$

As for the sources of local influence, no evidence could be found to indicate that red squad activities were shaped by other political or economic interests. The role of local interests in influencing red squad functions in Seattle is unclear. Nonetheless, it is a reasonable conjecture that Mayor Hanson had a hand in the activities of the Seattie red squad in view of his own self-proclaimed super-patriotism and his personal outrage about a bomb that was delivered, allegedly by "reds," to his office on April 28, 1919.

The influence of political leaders in Washington and Oregon on red squads was more palpable than the influence of powerful interests at either the national or the rocal leve1. Criminal syndicalism laws passed by the Washington and Oregon state legislatures were the main source of the red squads: Taw enforcement authority. Indeed, the investigation and arrest of Wobblies, Socialists, and Communists was a proper and legal police function under the criminal syndicalism laws in both states.

The Washington state legislature passed its first criminal syndicalism law in 1917, but Governor Ernest Lister's veto postponed $i$ ts implementation until the next legislative session in 1919. In 1919 the legislature adopted the law over Lister's veto and despite the protests of 1abor-supported King County*

* Seattle, a bastion of labor power in the state of Washington, is located in King County. 
representatives by a vote of 85 to 6.66 George Cotterill, a King County state representative and a former Seattle Mayor, opposed the bill because he felt that "criminal violence" could be prevented by a "less sweeping bi11."67 In other words, Cotterill was concerned that the tentacles of the criminal syndicalism law would grasp members of the A.F.L. as well as the Wobblies. Most of the other representatives were apparently unaware of the implications of the bill or were too stirred with the passions of the hunt to take a stand against measure whose principles clearly violated the U.S. Constitution.

Then, too, opposition to the bill would not have been "good politics" since the media as well as most of the predominantly rural populace in Washington supported its passage. In this regard, it is important to note that electoral pressures in the state in 1919 almost mandated that some type of criminal syndicalism law be passed by the legislature. In short, given that public opinion was strongly in favor of a repressive policy toward radicals, the state government was constrained to legislate that type of policy into existence.*

As far as the Seattle red squad was concerned, the content of the new law was more important than its origins. The new law defined criminal syndicalism to be an doctrine advocating:

*Andrew Hopkins made a similar point in his analysis of the findings from five case studies of pressure groups and the law in Australia. For a more detailed discussion of these studies, see Andrew Hopkins, "Pressure Groups and the Law," Contemporary Crises 3 (January, 1979), pp. 69-82. 
. . crime, sedition, violence, intimadation, or injury as a means or way of effecting or resisting any industrial, economic, or political change. If a person joined or associated with any organization that had these purposes, he/she came under the jurisdiction of the $7 \mathrm{aw} .68$

The Washington legislature also passed another criminal syndicalism statute which outlawed "sabotage." Sabotage was defined as the attempt to obstruct or injure any business hiring wage earners with the intent to impair the owner's control over the enterprise. 69

In effect, the criminal syndicalism laws made active membership in the I.W.W. a felony punishable by incarceration in the state penitentiary. The same laws were used against members of the Communist Labor Party in 1920. Authorities in Washington utilized these new laws extensively, obtaining 86 convictions under them in the 13 years following the passage of the laws. 70

In Oregon, the state Bar Association, conservative Republicans, and the state's major newspapers supported the passage of a criminal syndicalism law. ${ }^{71}$ The Bar Association was most vehement in its sponsorship of criminal syndicalism legislation, demanding that a law be drafted which wouTd: ". . . check and stamp out Bolshevism, anarchism, I.W.W.ism and all other isms that are subversive of sound and stable government. ${ }^{72}$

The first criminal syndicalism bill to be introduced in the Oregon legislature was presented by K. K. Kubli, a Republican representative and a politician who was backed by the $\mathrm{Ku} \mathrm{Klux} \mathrm{Kl}$ an for most of his political career. After Kubli's bill was tabled, a more 
stringent bill was introduced and was approved by large majorities in the Senate and the House in February 1919. The Senate vote was nearly unanimous in favor of the bill, although there was some minor opposition in the House from representatives of organized labor who argued that a criminal syndicalism 1 aw could adversely affect al1 unions. ${ }^{73}$

In terms of state-wide public opinion, the passage of the criminal syndicalism law seems to have reflected the sentiments of the vast majority of Oregonians. The Oregon 1 aw defined criminal syndicalism as follows:

The doctrine that advocates crime, physical violence, arson, destruction of property, sabotage, or other unlawful acts or methods as a means of accomplishing or effecting individual or political ends or as a means of accomplishing or effecting individual or political ends or as means of effecting individual or political revenue, or for profit. 74

The Oregon authorities, like the Washington authorities, vigorously enforced their criminal syndicalism law. It has been estimated that 184 persons, most of them members of the I.W.W., were arrested on criminal syndicalism charges in Oregon between February 1919 and December 1920.75 The Portland police used the law to arrest Wobblies selling newspapers on the streets 76 and to justify raids on the I.W.W. hall in February 1919.

The Portland red squad also made use of the criminal syndicalism law in 1919 and through the 1920s. Late in 1919, red squad members played a highty visible role in the Multnomah County Deputy District Attorney's anti-radical campaign which resulted in the arrest of 
several prominent Wobblies, one of whom was also the organizer of Portland's Soldiers', Sailors', and Workingmen's Council, and three members of the Communist Labor Party. 78 The red squad assisted the District Attorney in this campaign, arresting several of those who later were prosecuted in court.

Organizational Maintenance and Goal Transformation in Red Squads

The fear about radicalism that apparently had moved the citizens in Washington and Oregon tc support the passage of criminal syndicalism laws had ended by 1920 , according to one of the foremost experts on the period of 1919-1920.79 Yet, the red squads in Portland and Seattle remained in existence long after the public's concern about Bolshevik invaders had passed away. In fact, the Portland red squad appears to have been more active in the period of 1921-1922 than in the preceding two-year period.

This anomalous state of affairs can onily be understood if the red squads are viewed as organizational units within the larger elite-sponsored red hunting movement. The existence of movement organizations, such as red squads, is not solely determined by the public. Instead, these organizations appear to be greatiy influenced by the pwoerful interests which sponsor them and by internal bureaucratic forces. Barring the occurrence of any cataclysmic events in the larger society, these types of movement organizations can remain in existence so long as the organizations maintain their internal stability and retain their utility to their sponsors. In sum, unless there are internal problems or a powerful interest 
withdraws its support, the organization is likely to survive at least until the goals of the organization are reached.

In the case of the Portland red squad the goal of suppressing radicals was not completely realized in 1920 even though the public's fears had dissipated by that time. In order to attain its goal, the Portland red squad stayed in existence to suppress the I.W.W.-led strike of longshoremen in 1922. After the red squad and hundreds of other Portland police had squelched this strike by arresting the entire membership of the Marine Transport Workers local union of the I.W.W.,* the original goal of the Portland red squad may have been accomplished. However, the squad was able to remain in existence because the squad and local elites established new goals (e.g., spying on union employees and identifying radical employees) which served to sustain the squad's organizational 1 ife.

The essential point to bear in mind here is that the activities of the red squads seem to be best understood as the outcome of an interactive process, mainly involving the dominant political and economic interests as well as the labor radicals. Then, too, class relations, the functioning of the governmental apparatus and the rationality of the processes through which resources were mobilized and goals were transformed in response to the problem of labor radicalism also need to be emphasized in order to explain red squad operations. Above al1, by focusing on the social movement aspects

*For a description of the police response to this strike, see William W. Pilcher, The Portland Longshoremen: A Dispersed Urban Community (New York: Holt, Rinehart, and Winston, 1972), pp. 18-19. 
of the red squads, it is possible to better appreciate the roots of the repressive collective action of the Seattle and Portland police in $1919-1920$. 
REFERENCES--CHAPTER IX

1. Roberta Ash, Social Movements in America (Chicago: Markham Publishing Company, 1972), p. 180.

2. Herbert Aptheker, "Anti-Sovietism in the United States: An Overall View," Political Affairs (June, 1979), p. 4.

3. Melvyn Dubofsky, We Shall Be All: A History of the I.W.W. (New York: Quadrangle, 1969), p. 446.

4. Kinnear Papers, Address by Roy John Kinnear before the annual meeting of the Associated Industries of Seattle, June 6, 1924 (Seattle: University of Washington Library).

5. Scrapbook \#79, newspaper article dated October 6, 1920 from unknown news paper (Portland: Oregon Historical Society), p. 131.

6. Fred Ross, H. F. Prendergast, M. Provo, Gust Anderson, and C. J. Hayes, Report From the Labor Spy Investigation Committee to the [Portland] Centra] Labor Council, October 26, 1926 in Bery A. Green Manuscript Col7ection (Eugene, Ore.: University of Oregon).

7. Robert Murray, Red Scare (Minneapolis: University of Minnesota Press, 1955), p. 9.

8. Ray S. Baker, Woodrow Wilson: Life and Letters, 8 volumes (New York: Greenwood Press, 1927-39), VI, 506, footnote 2.

9. Woodrow Wilson, Address of June 14, 1917. Congressional Record, LV (65th Congress, First Session), Appendix, p. 334.

10. Murray B. Levin, Political Hysteria in America (New York: Basic Books, Inc., Publishers, 1971), pp. 28-90.

11. Tribune, February 7,1919, p. 6.

12. Levin, op. cit., p. 31.

13. Wal1 Street Journal, September 12, 1919, p. 1.

14. Times, November 12,1919, p. 1.

i5. Waiter Lippmann and Charles Merz, Untitied report, New Republic, supplement, August 4, 1920. 
16. Harry N. Scheiber, The Wilson Administration and Civil Liberties (Ithaca, New York: Cornell University Press, 1960), p. 48.

17. Edwin P. Hoyt, The Palmer Raids, 1919-1920 (New York: The Seabury Press, 1969), p. 52.

18. Murray, op. cit., p. 210.

19. George SouTe, Prosperity Decade: From War to Depression, 19171929 (New York: Rinehart, 1947), pp. 83-84.

20. Murray, op. cit., p. 108.

21. Dubofsky, op. cit., p. 473.

22. Roger Sale, Seatile: Past to Present (Seattle: University of Washington Press, 1978), $\hat{p} .137$.

23. Harvey $0^{\prime}$ Connor, Revolution in Seattle: A Memoir (New York: Monthly Review Press, 1964), p. 206.

24. Len De Caux, The Living Spirit of the Wobblies (New York: International Publishers, 1978), p. 143.

25. Senate Committee on the Judiciary, Charges of the IIlegal Practices of the Department of Justice (Washington, D.C.: U.S. Government Printing Office, 1921), p. 613; Benjamin Gitiow, I Confess (New York, 1940), p. 53; and A. Mitchel Palmer, Red Radical ism as Described by Its Own Leaders (Washington, D.C.: U.S. Government Printing Office, 1920), p. 13, cited by Murray, op. cit., p. 53.

26. Theodore Draper, The Roots of American Communism (New York: Compass Books, 1963).

27. Frederic L. Paxson, "The Great Demobilization," The American Historical Review, XLIV (January, 1939), p. 240.

28. Ibid., pp. $241 ; 244$.

29. Levin, op. cit., pp. 106-107.

30. Murray, op. cit., p. 7.

31. Ibid.

32. Office of the City Auditor, Payroll Register (Portland: City Hall Archives, 1912-1920); August Volimer, Survey- of the Portland Police Bureau (Portland, 1934), p. 118; Seattle Police Pension Fund, List of Pensions of Retired Officers (Seattle: Pension office, 1912-1920) 
33. News, March 4, 1918, p. 1; Oregon Journal, March 5, 1918, p. 5.

34. Murray, op. cit., p. 72.

35. Oregon Journal, October 26, 1917, p. 4.

36. News, April 23, 1919, p. 1.

37. The Portland Telegram, Apri1 23, 1919, p. 1.

38. Levin, op. cit., pp. 198; 201.

39. Murray, op. cit., p. 85.

40. Ibid., p. 87.

41. National Popular Government League, Report on the Palmar Raids, cited by Hoyt, op. cit., pp. 115-116.

42. Robert M. Fogelson, Big-City Police (Cambridge, Mass.: Harvard University Press, 1977), p. 88.

43. News, January 6,1920, p. 1.

44. Star, November 18, 1919, p. 1.

45. Gree, op. cit., p. 7.

46. The Industrial Worker, June 11,1919, p. 1.

47. News, op. cit.

48. Harvey A. Thatcher, Note to Chief of Police Leon V. Jenkins in Leon V. Jenkins Manuscript Collection \#1479 (Portland Historical Society).

49. Leon V. Jenkins, unpublished memoirs in Portland Chamber of Commerce Papers, Box 170 36, Police Department Folder, p. 5.

50. Ibid.

51. Hoyt, op. cit., p. 52.

52. News, February 3, 1919, p. 1.

53. The Industrial Worker, April 16, 1920, p. 3.

54. Times, December 31, 1919, p. 1; United States Attorney Manuscript Collection, \$1704B Telegram From Fred Haney, U.S. Attorney, to W. G. Tri11, District Attorney for Wheeler County Oregon, November 22, 1919, Telegram Book \#3, p. 262. 
55. The Industrial Worker, January 31,1920, p. 1.

56. Times, November 29, 1919, p. 1; Star, Apri1 23, 1920, p. 1; Times, December 11, 1919, p. 1.

57. Times, April 23, 1920, p. 1; Star, Apri1 23, 1920, p. 1.

58. Times, November 6,1920, p. 1; Times, December 11, 1919, p. 1; Times, June 24, 1920, p. 1.

59. Times, December 31, 1919, p. 1.

60. Times, November 19, 1919, p. 1.

61. William Short, History of the Activities of Seattle Labor Movenient and Conspiracy of Employers to Destroy It and Attempted Suppression of Labor's Daily Newspaper, the Seattle Union Record (Seattle: Union Record Publishing Company, 1999, p. 17 .

62. Oregon Chpater of the National Lawyers' Guild, Report of the Civil Liberties Committee on the Portland Red Squad (Portland, 1938).

63. Interview with member of Civil Liberties Committee by Dennis E. Hoffman (Portland, July 2, 1979).

64. Oregon Chapter of the National Lawyers' Guild, op. cit., p. 10.

65. Ibid, p. 11.

66. Post-Intelligencer, January 15, 1919, p. 1.

67. Star, January 14,1919, p. 1.

68. Session Laws of the State of Washington, Sixteenth Session, January 13, 1919 to March 13, 1919, Chapter 174, pp. 510-511.

69. Ibid., Chapter 173, pp. 517-518.

70. H. W. Stone, Oregon Criminal Syndicalism Laws and the Suppression of Radicalism by State and Local Officials (Unpublished Master's Thesis, Eugene, University of Oregon, 1933), p. 2.

71. M. Paul Holsinger, "Patriotism and the Curbing of Oregon's Radicals, 1919-1937," paper presented to the Seventeenth Annual Conference of the Western History Association (Portland: October 14, 1977), pp. 1-2.

72. Oregonian, December 21, 1918, p. 1. 
73. Mildred Cline, A Study of Criminal Syndicalism in Oregon, Bachelors' Thesis, Portland, Reed College, 1933, .5.

74. General Laws and Joint Resolutions and Memorials, adopted by the Thirteenth Regular Session of the Legislative Assembly (Salem, Oregon, 1919), Chapter 12, pp. 25-25.

75. Cline, op. cit., p. 9.

76. Oregonian, February 9, 1919, p. 1.

77. Oregonian, February 26, 1919, p. 1.

78. Uregonian, November 15,1919, p. 16; Journal, January 6,1920 , p. 1.; Oregonian, April 5, 1920, p. 8.

79. Robert Murray, op. cit., p. 263. 
CONCLUSIONS 
CHAPTER $X$

CHECKING SOME PROPOSITIONS ABOUT THE

POLICING OF LABOR WARS

\section{The Class Base of Police Repression}

The labor radicalism that developed from 1900 posed an increasingly dangerous challenge as to the police institution which guarded that:order. Having described the ways in which this challenge was met by the police in two cities, it is now useful to examine the major findings from the study of the Seattle and Portland police in light of the theoretical framework that was developed in the first part of the dissertation.

Class relations, including economic as well as political factors, are an appropriate starting point for this appraisal of how the empirical data on police response bear upon the propositions in the framework. Can the response of the Seattle and Portland police to the protest of labor radicals be explained by reference to economic factors alone? The answer is "no." Economic factors by themselves do not provide an adequate understanding of police response in Seattle and Portland; still, these factors did exert a great deal of direct and indirect influence upon police policies and actions.

The indirect influence of economic factors upon police response was far more important than their direct influence. Indeed, the 
particular issues around which both the labor radicals and the employers organized grew out of class relations. These issues included free speech, exploitive working conditions, worker control of industry, Americanism, and the open versus closed shop. It was in response to clashes between social classes and interest groups over these issues that the Seattle and Portland police were mobilized into action from 1912-1920.

One particular area where police actions may have been indirectly shaped by economic forces is the ideology of political officials and police authorities. Similarities between the belief systems of Mayors Baker and Hanson and the economically dominant class seem to have had a decisive effect on police policy during the Great Lumber Strike of 1917. A7though it is reasonable to posit that the super-patriotic and anti-radical thinking of the mayors was nurtured in an educational system whose function was to socialize persons into the acceptance of $i$ deas supportive of the capitalist system and reinforced by a media whose content was largely shaped by members of the economically dominant class, no hard data were collected in this study to establish these connections between class power, ideology, and police policy.

The direct influence of economic factors, although less pronounced than their indirect influence, was still evident in police-radical encounters. For one thing, direct influence was revealed in the employers' ability to control the actions of special police and members of red squads. Additionally, employers provided direct input into the formulation of police policy by virtue of their occupancy of policy-making roles on state labor regulatory commissions 
and to a lesser extent in municipal government. The Oregon State Welfare Commission, for example, was composed of persons from business backgrounds who possessed elite social credentials. More to the point, the content of this regulatory agency's policies pertaining to the cannery strike reflected the backgrounds of the Commission's members.

The direct influence of economic interests upon the police policies devised by city officials was less clear than in the case of the Welfare Commission. While all of the Seattle and Portland mayors from 1919-1920 were drawn from business-related occupations, their policies did not always benefit the economically dominant class. Indeed, police policies under Portland llayor Rushlight ânis under Seattle Mayors Gi1l and Cotteri11 at times were incongruent: with the immediate goals of some employers. In order to understarid the policies of these mayors it is necessary to consider politiral factors.

The more purely political aspects of class relations from 1912-1920 definitely played a part in shaping the police response. Linkages between class power, state power, and police actions were critical in this regard. In fact, it seems that the two key political facts in this study were the inability of the political powers that be to respond to the legitimate demands of unorganized cannery workers, unemployed persons, and striking lumber workers, and concurrently, the willingness of the holders of political power to mobilize repressive force against militant workers and radical political people who dared to challenge the status quo. 
Antithetical political constituencies in the case of the Cotterill administration, the structure of a commission form a government in the case of the Albee mayorality, and the war aims and international goals of the national political-economic leadership largely seem to have shaped the policy options available to the Seattle and Portland authorities. In general,then, these political forces helped to forge the context in which police policy was formulated and police strategy and tactics were carried out. In regard to the heavy doses of repression that were administered within this context, a confluence of political and economic forces was responsible for police actions. Specifically, it is necessary to inspect two of the social processes that were in motion during the period of 1912-1920. One of these processes can be referred to as the "consolidation of power." It should be remembered that police policies in 1912-1913 alternated between toleration of labor radicals and repression of them. These policy shifts do not seem to have been due to the factor of political party affiliation since there was no consistent relationship between a mayor's party affiliation and the police policy under his administration. The most tolerant police policies, for instance, were established in 19121913 by Mayor Cotteri11, who was a Demiocrat and by Mayor Rushiight, who was Republican.

What explains the tolerant policies of some city authorities in 1912-1913? This tolerance may have stemmed from the weak ties that existed between economic and political interests in 1912-1913. During these early years of conflict the lumber "barons," the 
shipping magnates, and other major economic interests were neither as weli-organized themselves nor as conscious of the necessity of protecting their interests through the control of the state apparatus as they were in later years. Then, too, the levels of labor unrest and international class conflict were lower in 1912 than in the post-1916 years. Additionally, it is doubtfu? that these large corporate concerns could have dominated the municipal governments of Portland and Seattle in 1912-1913 even if they had wanted to do so. Working class union people, middle class merchants, and other community interests appear to have had too tight a grip on the reins of city government in these years to have had power wrested away by outside industrial concerns. Evidence supporting the latter point can be found in the way that the 1913 power struggle was resolved between the Seattle Times, representing the interests of both the legal and illegal business entrepreneurs, and Mayor Cotteri11, representing organized labor, middle class Progressives, and the municipal government itself. The final resolution was actually a stalemate with neither side emerging as the winner. The implications to be drawn from this political clash are two-fold. First, the police policy of minimal intervention during this power struggle is in line with the proposition that a conflict between class and state interests promotes a policy of toleration for labor radicalism. Second, in regard to the point at hand about the process of consolidating power, it is obvious that class and state interests were not firmly united in Seattle in 1912. Stated in another way, the economic power of those who owned the forests, the mills, the shipping companies, and the vice operations had not yet been translated into political power. 
What happened to change the power relations between 1912 and 1917? A series of events at the local, state, national, and international levels altered the power arrangements in both Seattle and Portland. Some of these events such as the Great Lumber Strike of 1917 heightened the class consciousness of employers and other businessmen, impelling them to pressure municipal officials to use the police to blunt the radical threat. Other events such as World War I made governmental authorities more susceptible to these pressures because of the extreme dependence of the state upon major industrial and business concerns. Still other events like the Bolshevik Revolution in 1917 tended to increase the awareness of the state authorities and the major business and industrial firms insofar as the necessity of protecting the capitalist system from the reovlutionary currents of international radicalism was concerned. Taken together, these events fostered a consolidation of power by the ecoromically dominant class.

Another social process that figured into the shaping of police actions might be called the "decomposition of power." The "decomposition" seems appropriate because radical labor's power separated into its constituent parts after 1917. More to the point, the moves of third parties fueled the process through which the labor radicals lost power in Portland and Seattle. To be specific, the media, A.F.L. unions, and other community interests in Seattle and Portland shifted their positions vis a vis the employers and the labor radicals in response to many of the same events that served to consolidate power for the dominant economic interests. The war was 
sufficiently powerful by itself to push the Seattle Star and the Portland News from one side of the class confrontation to the other. For the A.F.L. affiliates in Seattle, the collapse of the General Strike and the fear of reprisals in the strike's aftermath sufficed to drive a wedge between the labor radicals and them. The police, who were themselves somewhat divided over the issue of how to handle labor unrest in 1912-1913, were clearly on the side of the economical7y dominant class by 1920. Federal intervention into police affairs and postwar demobilization were two forces which served to insure that the allegiances of police workers did not vacillate between the capitalist class and the working class.

The intersection of the power consolidation and power decomposition processes was marked by extreme police repression. The key point here is that the working class did affect police policy from 1912-1920. The working class, acting through coalitions consisting of the A.F.L., the I.W.W., and other organizations, provided an impetus toward a police policy of toleration of labor radicals in 1912-1913 and during the Seattle General Strike. Conversely, the working class affected police policy in a way that was detrimental to the Wobblies, Socialists, and Communists when the working class power coalitions decomposed, leaving the labor radicals isolated from the rest of the working class and thus subject to repression. The fact that heavy police repression tended to occur during the times when there was a decline in radical labor power supports the proposition that a sudden decrease in labor power leads to a policy of repression or a "Thermidorian reaction." 
As for the repression itself, it was produced by social processes that operated in a zigzagging fashion rather than in a slow, evolutionary manner. Police repression did not exist continuously through all stages of the conflict between the dominant political and economic interests and the labor radicals. Instead, the rhythms of repression were spasmodic, not running in any natural order of sequence. For example, after a steady period of repression in Seattle and Portland from 1917-1918, repression subsided during the Seattle General Strike. In fact, the proposition that toleration is likely to be adopted as a police policy in a revolutionary situation was borne out by the data on police actions during the General Strike.

A related observation on the discontinuity of repression is that the authorities were compelled by the labor radicals to suspend repressive police acts during the General Strike. This fact seems to indicate that the power of the economically dominant class was not monolithic even after its' consolidation of political and economic resources. Stated in another way, militant workers were able to exert influence over police policy even though the employers and industrialists had achieved high levels of organization and power in 1919.

Following the General Strike the level of repression zoomed up in both cities, reaching its zenith in 1919-1920. The high level of repression also was partly attributable to the leaders of police red squads who exploited the concerns of the employers about radicalism in order to promote their own organizational and 
seif-interests. Red squad leaders used repression as a political resource.* What happened was that the dramatic "revelations" produced by the raids and other more sordid adventures of the red squads activated employers into the role of benefactors who then provided direct assistance to red squad members in the form of monetary contributions. As a consequence, the repression seems to have literally fed on itself in a self-perpetuating fashion.

\section{The Structuring of Police Mobilization and Collective Action}

While an examination of the class base of repression points out the general contours of the police response, it does not resolve the issues of why and how the police are mobilized to act collectively against the labor radicals. It is appropriate to address these issues at this point. When specifically considering the matters of police mobilization and collective action, the findings from the comparative study of Seattle and Portland are somewhat striking. They are striking because most of the propositions regarding the relationships between police actions and various social factors were supported by the data in Chapters IV-IX.

The data on police mobilization indicate that high levels of labor unrest as measured by strike activity tended to be related to increases in the size of the Seattle and Portland police departments and to the modification of organizational arrangements in order to more effectively police labor wars and to suppress radicals. In terms

*Michael Lipsky conceptualized some of the ways in which protest may be used as a resource in "Protest as a Political Resource," American Political Science Review, 62 (December, 1968), pp. 1144-1158. 
of the effect of labor unrest on size, it appears that most of the increases in police manpower that occurred because of strikes were due to the hiring of special police on a temporary basis. Hence, the effects of labor unrest on departmental size were short-term in nature. As for changes in organizational arrangements, it was almost customary for the Seattle and Portland police to alter deployment practices in precincts in accordance with the exigencies of labor unrest. Then, too, reserve forces, war emergency squads, and red squads were created for the purpose of dealing with the labor radicals.

One proposition about police mobilization that was not supported was the proposition that a high level of labor power calls forth a greater emphasis on commitment mechanisms in police departments. While there were minor increments in police salaries from 1912 to 1920 , it does not appear that wage increases for the police were spurred on by the acquisition of power by the labor radicals. Other commitment mechanisms, however, were utilized as substitutes for financial incentives by the police. For instance, public recognition for patriotic service in the pages of the daily newspapers may have boosted the morale and loyalty of red squad members. Still, this public recognition was accorded to the "red hunters" at a time when the level of labor's power was low rather than high.

Turning to the propositions on collective action, the data indicate that increases in the level of labor unrest were related to increases in the amount of emphasis placed on proactive police strategies. More specifically, police riots and attacks tended to 
decline in importance over the period of 1912-1920, while police raids became more frequent and prominent during this same period. While it must be acknowledged that police riots and attacks were to some extent police-initiated events, these phenomena largely were precipitated by things such as a wagon passing by with a red flag attached to it and free speech fighters refusing to obey police orders. Conversely, the raids involved a more planned, deliberate type of police action than did the riots and attacks.

The data are less clear with respect to preventive strategies. In fact, since the resources devoted to preventive activity were not compared over time, there is no way to evaluate the proposition that preventive strategies were stressed when there were low levels of unrest. However, one important finding emerged in regard to preventive strategies. It was discovered that there were no sharp divisions betwieen proactive strategies which have been typically associated with repression and preventive strategies which have usually been thought to be associated only with reform and pacifism. Indeed, it appears that the utilization of both proactive and preventive strategies reaped repressive outcomes in the case of the Portland police.

The significance of this finding resides more in the questions that it raises than in the answers it provides to the social scientist. If there was no fundamental difference between the outcomes of these two strategies, what choice did the police have in terms of their response to the labor radicals? If there was no choice to be made with regard to strategic outcomes, then was the element of choice present with respect to the types of political 
action possible for the police? Did the police have a choice between reactionary collective action and progressive collective action? The data in this study give the impression that the answer to all three of these questions is a qualified "no."

The query about the political cast of police actions seems to be the pivotal question. During the entire period of 1912-1920 the outstanding instance of progressive action on the part of the city police was the attempt of rank and file police in Portland to start a union in 1919. This endeavor was promptiy smashed by Mayor Baker and other city authorities. In a somewhat different manner, the sympathies of Guy Fuller and other street police for the plight of the striking fruit-sorters in Portland became submerged in the bureaucratic machinery of a reform administration. Moreover, is it difficult to imagine how the police could have behaved differentiy than they did in their encounters with the labor radicals, given their own position in the class structure. As the data on the years 1919-1920 seem to indicate, the police occupation was in a declining position relative to other occupations. This structural condition probably further propelled the police to participate in reactionary political action.

Some other propositions that were supported by the findings were those on the scope, size, and intensity of police action. Specifically, the evidence showed that when the I.W.W. broadened its scope of mobilization efforts by organizing the unemployed, the police also enlarged the scope of their actions by "vagging" unemployed persons. No data were collected on the relationship 
between labor unrest and changes in police arrest practices pertaining to the regular labor force. However, it would be surprising if the proportion of laborers arrested did not increase during the Great Lumber Strike of 1917.

As for the intensity of police action, one rather interesting observation can be gleaned from the data on the violence exhibited by the Seattle and Portland police in 1919-1920. This observation is that the proposition about the relative levels of police violence under a condition of public hysteria versus a condition of high labor unrest may be inappropriate since police violence in 1919-1920 apparently was neither begat by a "red scare" not caused by labor unrest. Instead, police actions vis a vis radicals in 1919-1920 must be regarded as part of a broad red-hunting movement that was mainly sponsored by national political and economic interests. Another finding in regard to police violence is that the riotous behavior of the Portland police in handling the cannery strike in 1913 did seem to radicalize some middle class persons who had previously been uncommitted to either side in the labor dispute. This finding is consistent with the proposition that the use of excessive force is likely to radicalize third parties to the class struggle.*

Besides breaking down police response into the above-discussed parts, it is useful to take a holistic view of the police response to the labor radicals. When police response is considered as a

*Due to data limitations, the other propositions about police violence were not explored in the dissertation. 
single entity, one can not help but be struck by the impression that the police response to labor radicalism in 1919-1920 was characterized by an incredible amount of structuring. Even the people who controlled the police seemed to be controlled at times; even the reforming of the structure of municipal government failed to produce a more humane, tolerant police response; the only way out for the individual officer seemed to be permanent, e.g., quit the department and procure better work elsewhere. In sum, the individual police officer's freedom of choice in terms of the policy, strategy, and tactics for dealing with labor radicals was drastically constrained by structural forces.

The Police Function Revisited

This dissertation began with a statement on the importance of understanding the police function in terms of economic interests, power relations, and class conflict within particular communities. Then, too, it has been asserted that linkages between the economically dominant class, political leaders and law enforcement officers must be regarded as dynamic phenomena which are in motion, shifting their course and altering the context in which the police policy is formulated and carried out by patrolmen and detectives. Above all, it has been argued that the interrelatedness of class, state, and police power is a central fact in police mobilization and collective action.

The criminal law is one of the concrete points at which an analysis of the police must commence in order to fully capture the interlocking nature of economic and political phenomena in shaping 
the police response. In the case of the Seattle and Portland police, data on the origins of the criminal syndicalism laws underscored the mutual and sometimes reciprocal relations between these social phenomena. It was shown that these laws in Oregon and Washington emerged in an environment that was largely formed by national economic and political interests and by international and national, and regional class conflict. The actual process of making it a crime to be a member of the I.W.W. Was managed by state political leaders who appear to have been supported by public opinion. Both the state politicians and the Oregon and Washington publics, in turn, probably were influenced by the ebb and flow of the national red hunting movement. The result of these ties between international, national, and state level forces was legislation which rendered the hunting of Wobblies, Socialists, and Communists to be a legitimate police function.

Another necessary point of concentration in the analys is of the police function is the application of criminal law. Here differences in power must be taken into account. Police actions in regard to the enforcement of criminal syridicalism and vagrancy laws in Portland and Seattle amplified the theme that law enforcement policy and practices are to some extent influenced by the power of labor radicals in relation to the power of the economically dominant class:

With respect to the application of the criminal syndicalism laws, the "spy for hire" scheme of Portland police exceeded the legal boundaries of the syndicalism statute. This excess was not 
due soleiy to the abuse of police discretion. Rather these extra curricular police activities were the result of the employers' direct influence over the police as well as the bureaucratic and financial interests of red squad members. At the same time, it must be recognized that the Wobblies and the other radicals lacked the power and status to be able to enter into a similar relationship with the authorities.

Similarly, the manner in which vagrancy laws were enforced protected the most powerfut interests in the community. Since labor lacked any representation in Portland's commission form of government, there was little chance of the lumber barons being "vagged" by the Portland police. This was true even though the behavior of many of the mill owners and logging company entrepreneurs may have been litile different from the behavior of those who were arrested for vagrancy. Indeed, the lumberman and the typical unemployed protestor in 1913-1915 seem to have shared the status of being one who wandered about idly and performed little or no work! The important difference between the lumberman and the unemployed person, of course, was that the former possessed considerably more power than the latter.

Power relations also affected the application of the law in the aftermath of the Seattle General Strike. The municipal authorities in Seattle displayed a great deal of selectivity in choosing the "whipping boys' for the strike. They sent a hail of repression down on the politically marginal and powerless Wobblies instead of attacking the stronger forces that were responsible for the strike. 
As important as power differences were in determining the response of the Seattle and Portland police, they do not suffice alone as an explanation of police repression. It is important to see that the conflict between the capitalist and the working class provided the backdrop for the day-to-day maneuvers of the police. This conflict was not a static phenomenon;* instead it was a social formation, arising from processes which evolved over a period of time.

The police function was enlarged or dirinished, strengthened or weakened, and stressed or downplayed depending upon the relations between these classes (and to a lesser extent upon the actions of other classes and groups such as the middle class and the unemployed). In 1912-1913, for instance, the Seattle and Portland police on occasion filled the role of a neutral arbiter in skirmishes under the conditions of a division between the dominant power interests and relatively low levels of conflict and unrest. By contrast, the role of the Seattle and Portland police in 1917-1919 often was that of a military warrior, raiding and attacking all opposition to the established social order under a different set of social conditions than existed in 1912-1913. Gains in cohesion and consensus among the dominant political and economic interests, along with much higher levels of unrest, were reflected in the tendency of the police to retain a repressive policy toward labor radicals throughout most of this period.

*Parts of this analysis derive from the thinking of $E$. P. Thompson, The Making of the English Working Class (New York: Vintage Books, 1966). 
Care needs to be taken, however, not to pigeonhole police response as being totally repressive or tolerant or to stop history at a given point and assert that the police function was "thus and such" in a given year. It must be recognized that the police function is not a thing. Instead it is a sociological phenomenon whose nature can be inferred by observing police actions in the context of specific class relations over a period of time. Taking this long view of police-radical encounters in Seattle and Portland from 1912-1920, it appears that the main continuity in these relations was that the police tended to invoke force and violence whenever class conflict became irreconcilable.*

The anti-radical police violence in Portland in 1913 and the refusal of the Seattle police to protect the property of Socialists in the same year can be viewed as expressions of the police functioning to perpetuate the class system in the specific situations where the cannery workers, the free speech fighters, and the Socialists refused to accept the pattern of social relations that made up their lives. During the period, 1917-1919, the contradictions and differences between the capitalist and working classes became even more apparent to both sides to the point where the relations between the two became highly conflict-laden. Again, the basic rationale of police work in Seattle and Portland under these sorts of conditions was the use or potential use of force. This observation is supported

*Paul Takagi offered this observation in "LEAA's Research Solicitation: Police Use of Deadly Force," Crime and Social Justice (Spring-Summer, 1979), p. 55. 
by the existence of raids, dragnets, and gargantuan displays of police firepower that characterized this period.

\section{Back to Social Theory}

As a concluding addendum to this discussion of the police function, it seems fitting to offer several observations on the apparent as well as the real weaknesses of the present study. First, a statement about the generalizeability of the findings is in order. An obvious criticism of this research is that police behavior in Seattle and Portland from 1912-1920 may not have been representative of police behavior in other cities and in other times. This is a valid point to make in regard to this study. A closely related, yet not entirely appropriate criticism is that this study lacks external validity because of the crises that occurred in the period that was under investigation.

The latter criticism is sumewhat inappropriate because wars and massive unemployment are integral parts of the capitalist system which have recurred on a fairly regular basis throughout the twentieth century in the U.S. Crises in parts of the capitalist system are often produced by the system itself in order to restore equilibrium in other parts of the system. ${ }^{1}$ Specifically, the unemployment crisis of 1913-1915 seems to have been precipitated by overproduction, while U.S. involvement in World War I was due, in part, to the perception that the survival of the capitalist system depended upon overseas economic expansion. ${ }^{2}$

Suffice it to note here that crises serve to galvanize class conflict in general and to stimulate the police in particular to perform 
the function of preserving the class system. To support this claim, it can be noted that the Portland police employed force against the "Hungry Hundred" in an effort to blunt the thrust of the unemployed army's protest during the crisis of 1913-1915. Additionally, World War I served as a proximate force that led to a quasi-nationalization of the Seattle and Portland police in 1917-1918. The national influence that was exerted over the city police and the manifestations of this control benefitted the dominant political and economic interests in the U.S. While it is clear that the unemployment and war crises affected police response in important ways, it is still necessary to keep in mind that these crises and the outcomes wrought by them were part and parcel of larger conflicts and contradictions within the capitalist system in 1912-1920.

Another possible criticism of this dissertation is that the analysis is somewhat mechanical and features an over-socialized conception of reality. This is a criticism that is to be expected given the limitations of the framework that has been constructed. Inasmuch as the mobilization perspective that has been integrated into the framework is a purposive model, it is not a surprise that the analysis in this dissertation depicts the Seattle and Portland police as acting with some sort of design in mind.* Neither is it a shock that police actions were seen as serving a specific function in a capitalist society in view of the emphasis on Marxian social theory.

*Much of the commentary in this section is drawn from the observations made by Charles Tilly in From Mobilization to Revolution (Reading, Mass.: Addison-Wesley Publishing Company, 1978), pp. 229231 . 
It is hoped that other studnets of police collective action will be able to "bring human beings" into their analysis.* It should be pointed out, however, that if accounting for individual differences and personality characteristics is a perplexing task in contemporary social scientific studies, it is even more difficult in historical research. Diaries, scrapbooks, and other similar documents are required in order to even begin to measure these types of factors in historical studies. There was a paucity of this type of data available for the investigation of police response in Seattle and Portland.

Another problem with the present study of the police response to labor radicalism is that there has been no clear delineation between the descriptive and causal explanations of police actions.** For the most part, the observations about the police response in Seattle and Portland were surted into the categories of interests, organization, mobilization, repression, power, and collective action itself. This ordering of categories led to the view that the police attempted to achieve their interests with the resources available to them within the limits set by their class position, their function as part of the state apparatus, and so on. A causal explanation also implicitly figured inio this analys is of police response. In

*For an argument in favor of bringing human beings back into social research, see George C. Homans, "Bringing Men Back In," Americal Sociological Review, 29 (December, 1964), pp. 809-818. ATso see Dennis Wrong, "The Oversocialized Conception of Man in Modern Sociology," American Sociological Review, 26 (Apri1, 1961), pp. 183-193.

**This is a general problem of historical interpretation. 
adhering to Marxian social theory, it was stressed that large scale social changes affected the interests of organizations contending for power and, as a consequence, affected their mobilization and collective action.

Two points must be understood with respect to both types of explanation. First, the descriptive and causal types of explanation, as they were utilized in this study, involved two different levels of analysis. Whereas the descriptive form mainly operated at the organization level, the causal form operated at a social structural level. Second, the level of explanation achieved in this dissertation reflects a very primitive stage in the development of a theoretical perspective on police collective action. Again, however, this is a result that is to be expected given the exploratory nature of the study. Should students of police response choose to move beyond this primitive stage, the tasks of explicating the major dimensions of causation, identifying the role of other etiological processes such as the proletarianization of police labor, and then specifying the linkages bewteen the different levels of analysis remain to be accomplished. In addition, the problem of integrating descriptive and causal models must be resolved in order for knowledge to develop cumulatively in this area of police studies.

With this great amount of unfinished business left for those interested in studying police collective action, what should be the overarching goal of future research in regard to this area of study? This question brings the dissertation around full circle from the heights of social structural forces down to the level of the individual 
social scientist. The best reserach agenda for future police studies would seem to be one that includes problems that are relevant to the contemporary urban crises. "Relevant" problems refer, in particular, to topics and episodes of police collective action that might shed light upon how individual human beings can effectively resist some of the large-scale structural transformations of the past and present which rob individuals of their power and hope. 


\section{REFERENCES--CHAPTER $X$}

1. Charles H. Anderson, The Political Economy of Social Class (Englewood Cliffs, N.J.: Prentice-Hal1, Inc., 1974), p. 37.

2. William Appleman Williams, The Contours of American History (Chicago: Quadrangle Books, 1966), p. 415.

3. Anderson, op. cit., p. 37. 


\section{BIBLIOGRAPHY}

I. BOOKS

A. Police

Center for Research on Criminal Justice 1977. The Iron Fist and the Velvet Glove, 2nd ed., San Francisco: Garrett

Press.

Cobb, Richard 1970. The Police and the People: French Popular Protest, 1789-1820, New York: Oxford University Press.

Fogelson, Robert M. 1977. Big-City Police, Cambridge, Mass.: Harvard University Press, 1977.

Gibbons, Don C. 1977. Society, Crime, and Criminal Careers, 3rd ed., Englewood Cliffs, N.J.: Prentice-Ha!T, Inc.

Graham, Hugh D. and Ten R. Gurr 1969. The History of Violence in Americá, New York: Bantam Books.

Hartjen, Clayton A. 1974. Crime and Criminalization, New York: Praeger Publishers.

Hoyt, Edwin P. 1969. The Palmer Raids, 1919-1920, New York: The Seabury Press.

Kah10, Dorothy Mi1ler 1907. History of the Police and Fire Departments of the City of Seattle, SeattTe: The Lumbermen's Printing Co.

La Fave, Wayne R. 1965. Arrest: The Decision to Take a Suspect Into Custody, Boston: Little, Brown and Company.

Lane, Roger 1975. Policing the City: Boston, 1822-1885, New York: Atheneum.

Manning, Peter K. and John Van Maanen (eds.) 1978. Policing: A View From the Street, Santa Monica, Calif.: Goodyear Publishing Company, Inc.

Momboisse, Raymond M. 1967. Riots, Revolts, and Insurrections, Springfield, Ill.: Charles C. Thomas Publisher. 
O'Connor. Robert J. and Bernard Gilman 1978. Preventing Crime, Beverly Hills, Calif.: Sage Publications.

Preston, William 1963. Aliens and Dissenters: Federal Suppression of Radicals, 1903-1933, Cambridge, Mass.: Harvard University Press.

Reiss, Albert J. 1971. The Police and the Public, New Haven, Conn.: Vale University Press.

Richardson, james F. 1974. Urban Police in the United States, Port Washington, N.Y.: Kennikat Press.

Schur, Edwin 1973. Radical Non-Intervention: Rethinking the Delinquency Problem, Englewood Cliffs, N.J.: Prentice-Hall.

Skolnick, Jerome H. 1967. Justice Without Trial, New York: John Wiley and Sons, Inc.

Stark, Rodney 1972. Police Riots, Belmont, Calif.: Wadsworth Publishing Company.

Walker, Samuel 1977. A Critical History of Police Reform, Lexington, Mass.: Lexington Books.

Wilson, James Q. 1977. Thinking About Crime, New York: Vintage. 1968. Varieties of Police Behavior, Cambridge, Mass.: Harvard University Press.

\section{B. Labor}

Bernstein, Irving 1970. The Lean Years: A History of the American Worker, 1920-1933, Baltimore: Penguín Books.

Brooks, John G. 1971. Labor's Challenge to the Social Order, Port Washington, N.Y.: Kennikat Press.

DeCaux, Len 1978. The Living Spirit of the Wobblies, New York: International Publishers.

Draper, Theodore 1963. The Roots of American Communism, New York: Compass Rooks.

Dubofsky, Melvyn 1969. We shall Be All: A History of the IWW, New York: Quadrangle.

Foner, Phillip S. 1976. History of the Labor Movement in the United States, Volume IV, New York: International Publishers. 
Friedheim, Robert 1964. The Seattle General Strike, Seattle: University of Washington Press.

Gitlow, Benjamin 1940. I Confess, New York.

Gutman, Herbert 1976. Work, Culture, and Society in Industrializing America, New York: Vintage Books.

Hawley, Lowe11 S. and Ralph Bushne11 Potts 1953. Counsel for the Damned: A Biography of George Francis Vanderveer, Philadelphia: Lippincott.

Hoffman, Claude E. 1968. Sit-Down in Anderson: UAlW Local 663, Anderson, Indiana, Detroit: Wayne State University Press.

Lens, Sidney 1969. Radical ism in America, New York: Thomas Y. Crowell Company.

Lynd, Staughton (ed.) 1973. American Labor Radicalism, New York: John Wiley and Sons, Inc.

Mi11s, C. Wright 1948. The New Men of Power, New York: Harcourt Brace Jovanovich, Inc.

Mortimer, Wyndham 1971. Organize! My Life As A Union Man, Boston: Beacon.

0'Connor, Harvey 1964. Revolution in Seattle: A Memoir, New York: Monthly Review Press.

Pilcher, William W. 1972. The Portland Longshoremen: A Dispersed Urban Community, New York: Holt, Rinehart, and Winston.

Root and Branch (eds.) 1975. The Rise of Workers'Movements, Greenwich, Conn.: Fawcett Publications, Inc.

Ross, Car7 1977. The Finn Factor in American Labor, Culture, and Society, New York MiTTs, N.Y.: Parta Printers, Inc.

Short, William 1979. History of the Activities of Seattle Labor Movement and Conspiracy of Employers to Destroy It and Attempted Suppression of Labor's Daily Newspaper, the Seattle Union Record, Seattle: Union Record Publishing Company.

Smith, Walker C. 1975. The Everett Massacre, Chicago: I.W.W. Publishing Bureau.

Soule, George 1947. Prosperity Decade: From War to Depression, 1917-1929, New York: Rinehart. 
Strong, Anna Louise 1935. I Change Worlds, New York: Henry Holt and Company.

Tawney, Richard Henry 1967. The Agrarian Problem in the Sixteenth Century, New York: Harper and Row.

Thompson, E. P. 1966. The Making of the English Working Class, New York: Vintage Books.

Thompson, Fred W. and Patrick Marfin 1976. The I.W.W.: Its First Seventy Years, 1905-1975, Chicago: Industrial Workers of the World.

Tyler, Robert 1967. Rebels of the Woods: The I.W.W. in the Pacific Northwest, Eugene, Ore.: University of Oregon Books.

\section{Politics, Economy, and Society}

Anderson, Charles H. 1974. The Political Economy of Social Class, Englewood Cliffs, N.J.: Prentice-Hall, Inc.

Ash, Roberta 1972. Social Movements in America, Chicago: Markham Publishing Company. Company.

1977. Social Change, Chicago: Rand McNally Publishing

Baker, Ray S. 1927-39. Woodrow Wilson: Life and Letters, 8 volumes, New York: Greenwood Press.

Broom, Leonard and Philip Selznick 1973. Sociology, 5th ed., New York: Harper and Row.

Domhoff, G. William 1976. Who Rules America, Englewood Cliffs, N.J.: Prentice-Ha71, Inc.

Dun and Bradstreet. Seattle (New York: Dun and Bradstreet, Inc.

Gamson, William A. 1968. Power and Discontent, Homewood, I11.: Dorsey Press.

Gaston, Joseph 1911. Portland, Its History and Builders, Volume I, Portland.

Gurr, Ted R. 1970. Why Men Rebel: Princeton, N.J.: Princeton University Press.

Hancock, R. Kelly 1971. "Collective Behavior and Social Movements," in Reece McGee (ed.) Sociology: An Introduction, Hinsdale, 111.: The Dryden Press. 
Hanson, 01e 1920. Americanism Versus Bolshevism, New York: Doubleday, Page and Company.

Kolko, Gabriel 1976. Main Currents in Modern American History, New York: Harper and Row Publishers.

Levin, Murray B. 1971. Political Hysteria in America, New York: Basic Books, Inc., Publishers.

MacCoil, E. Kimbark 1976. The Shaping of a City, Business and Politics in Portland, Oregon 1885 to 7915 , Portland: The Georgian Press Company.

Marx, Karl 1904. A Contribution to the Critique of Political Economy, Chicago: Charles H. Kerr and Company.

Morgan, Murray 1978. Skid Road: Seattle: Her First 125 Years, Sausalito, Calif.: Comstock.

Murray, Robert 1955. Red Scare, Minneapolis: University of Minnesota Press.

Oberscha17, Anthony 1973. Social Conflict and Social Movements, Englewood Cliffs, N.J.: Prentice-Hall, Inc.

Piven, Francis Fox and Richard A. Cloward 1971. Regulating the Poor: The Functions of Public Welfare, New York: Vintage Books.

Platt, Anthony 1977. The Child Savers: The Invention of Delinquency, 2nd ed., Chicago: University of Chicago Press.

Rude, George 1964. The Crowd in History, New York: John Wi Tey and Sons, Inc.

Sale, Roger 1978. Seattle: Past to Present, Seattle: University of Washington Press.

Scheiber, Harry N. 1960. The Wi ison Administration and Civil Liberties, Ithaca, N.Y.: Cornell University Press.

Stave, Bruce (ed.) 1975. Socialism and the Cities, Port Washington, N.Y.: Kennikat Press.

Tilly, Charles 1978. From Mobilization to Revolution, Reading, Mass.: Addison-Wes ley Publishing Company.

Weinstein, James 1967. The Decline of Socialism in America, 19121925, New York: Monthly Review Press.

Williams, William Appleman 1966. The Contours of American History, Chicago: Quadrangle Books. 
D. Miscellaneous

Fisher, David Hackett 1970. Historians Fallacies, New York: Harper and Row.

Larson, Margali 1977. The Rise of Professionalism: A Sociological Analysis, Berkeley, Calif.: University of California Press.

Teggart, Frederick J. 1977. Theory and Processes of History, Berkeley, Calif.: University of California Press.

II. PUBLISHED REPORTS AND OTHER DOCUMENTS

A. Portland

City of Portland 1913. City Directory, Portland: R. L. Polk and Company, Inc.

Portland. 1912-1920. Mayor's Message and Annual Report, HalT Archives.

1912-1920. Payroll Register, Portland: City

\author{
B. Seattle
}

City of Seattle 1912; 1913; 1920. Annual Report of the Police Department, Seattle. 1912-1920. List of Pensions of Retired Officers, Seattle: Pension Office.

$$
\text { C. Oregon }
$$

Oregon State Legislature 1919. General Laws and Joint Resolutions and Memorials, Thirteenth Regular Session of the Legislative Assembly, SaTem, Ore.: State Printing Company.

0'Hara, Edwin 1916. A Living Wage By Legislation: The Oregon Experience, Salem, Ore.: State Printing Company. 
0'Hara, Edwin 1912. "Welfare Legislation for Women and Minors," in Report of the Social Survey Committee of the Consumer's League of Oregon, Portland: Keys tone Press.

Oregon Chapter of the National Lawyers' Guild 1938. Report of the Civil Liberties Committee on the Portland Red Squad, Portland.

Oregon State Board of Control 1913-1969. Minutes, RGC9 Session 76A-39, Item 3, Salem, Ore.: Board of Control.

Ross, Fred, H. F. Prendergast, M. Provo, Gust Anderson, and C. J. Hayes 1926. Report Fran the Labor Spy Inves ti gation Committee to the [Port]and] Central Labor Counci], Portland.

Wood, Arthur Evans 1914. A Study of the Unemployed in Portland, Oregon, Portland: Reed College Social Service Bulletin.

D. Washington

Washington State Legislature 1919. Session Laws of the State of Washington, Sixteenth Session, Olympia, Washington.

\section{E. United States}

Palmer, A. Mitchel 1920. Red Radicalism as Described by Its Own Leaders, Washington, D.C.: U.S. Government Printing Office.

Senate Committee on the Judiciary 1921. Charges of the Illegal Practices of the Department of Justice, Washington, D.C.: U.S. Government Printing Office.

Wilson, Woodrow 1917. Address of June 14, 1917, Congressional Record, LV 65th Congress, First Session, Appendix, Washington, D.C.: U.S. Government Printing Office.

E. Miscellaneous

Dowe11, Eldridge F. 1939. "A History of Criminal Syndicalism Legislation in the United States," The Johns Hopkins University Studies in Historical and Political Science Series, LVI, No. T, Baltimore.

Harvard University 1963. A Yearbook of the Graduate School of Public Administration, Cambridge, Mass.: Harvard University.

Illinois Supreme Court 1922. Transcripts of People v. Lloyd, 304 Illinois 23 (136 N.E. 505), Springfield, Ill.: RemingtonRand microfilm. 


\section{UNPUBLISHED REPORTS AND THESES}

Abramson, Paul 1952. The Industrial Workers of the World in the Northwest Lumber Industry, Portland: Bachelor of Arts Thesis, Reed College.

Cline, Mildred 1933. A Study of Criminal Syndicalism in Oregon, Portland: Bachelor's Thesis, Reed College.

Nelson, Doug 1971. "The Portland Industrial Workers of the World: Their Politics and Activities, 1917-1924," Portland: Manuscript, Portland State University.

Portland Police Bureau 1913. Portland Police Detective Notebooks, Volume 30, Portland: Portland State University Archives.

Saville, M. E. Colonel 1918. Report to the Commanding General of the U.S. Army, March 30, 1918, Washington, D.C.: Department of Justice File 186701-49-88.

Stone, H. W. 1933. Oregon Criminal Syndicalism Laws and the Suppression of Radicalism by State and Local Officials, Eugene, Ore.: Master's Thesis, University of Oregon.

Vollmer, August 1934. Survey of the Portland Police Bureau, Portland.

IV. UNPUBLISHED MANUSCRIPTS AND SCRAPBOOKS

A. Oregon

Green, Bery1 A. 1962. Untitled Autobiography, Volume 4, Eugene, Ore.: University of Oregon.

Jenkins, Leon V. Unpublished Memoirs, Port:1and: Portland Chamber of Commerce Papers, \#1473, Bü 170 36, Po7ice Department Folder.

Kosokoff, Sandra 1971. "The Radicalization of Marie Equi," Portland: Oregon Historical Society.

Scrapbook \#79, Portland: Oregon Historicai Scciety.

United States Attorney Manuscripts \#1704B 1919. Portland: Oregon Historical Society. 


\section{B. Washington}

Industrial Espionage Papers 1920. Seattle: Univeristy of Washington Library.

Kinnear Papers 1924. Seattle: University of Washington Library.

Merrill Ring Company Papers 1916-1918. Seattle: University of Washington Library.

Puget Mill Company Papers 1916-.1919. Seattle: University of Washington Library.

U.S. Department of Labor File 33/574 1916-1918. Record Group 280, Washington, D.C.: National Archives.

U.S. Department of Justice File 186701-49-2 1916-1918. Record Group 60, Washington, D.C.: National Archives.

--File 186701-49-51.

--File 190159-48.

--File 186701-49-52.

--File 186701-61-1.

V. ARTICLES IN JOURNALS AND BOOKS; PAPERS

PRESENTED AT'PROFESSIONAL MEETINGS

\section{A. Police}

Belknap, Michael R. 1978. "The Mechanics of Repression: J. Edgar Hoover, the Bureau of Investigation and the Radicals, 19171925," Crime and Social Justice, 7 (Spring-Summer), pp. 49-58.

Black, Donald J. 1978. "The Mobilization of Law," in Peter K. Manning and John Van Maanen (eds.), Policing: A View From the Street, Santa Monica, Calif.: Goodyear Publishing Company, Inc., pp. 167-187.

Ga17iher, John F. 1976. "Explanations of Police Behavior: A Critical Review and Analysis," in Arthur Niederhoffer and Abraham S. Blumberg (eds.), The Ambivalent Force, 2nd ed., Hinsdale, I11.: The Dryden Press, pp. 65-72.

Haller, Mark H. 1976. "Historical Roots of Police Behavior: Chicago, 1890-1925," Law and Society Review, 10 (Winter), pp. 303-324. 
Harring, Sidney 1977. "Class Conflict and the Suppression of Tramps in Buffa10, 1892-1894," Law and Society Review, 11 (Summer), pp. 873-911.

1976. "The Development of the Police Institution in the United States," Crime and Social Justice, 5 (Spring-Summer), pp. 54-59.

Harring Sidney L. and Lorraine M. McMullin 1975. "The Buffalo Police 1872-1900: Labor Unrest, Political Power and the Creation of the Police Institution," Crime and Social Justice, 4 (Fal1-Winter), pp. 5-14.

Harring, Sidney Tony Platt, Richard Speiglman, and Paul Takagi 1977. "The Management of Police Killings," Crime and Social Justice, 6 (Fall-Winter), pp. 34-44.

Hartjen, Clayton A. 1972. "Police-Encounters," Criminology, 10 (May), pp. 61-84.

Hoffman, Dennis E. and Gary R. Perlstein 1979. "A Social History of Police Work With Juveniles," LEA Journal (to be published).

Robinson, Cyril D. 1975. "The Mayor and the Police--The Political Role of the Police in Society," in George L. Mosse (ed.), Police Forces in History, Beverly Hills, Calif.: Sage Publications, pp. 277-315.

Schlossman, Steven and Stephanie Wallach 1978. "The Crime of Precocious Sexuality: Female Juvenile Delinquency in the Progressive Era," Harvard Educational Review, 48 (February), pp. 65-94.

Takagi, Paul 1979. "LEAA's Research Solicitation: Police Use of Deadly Force," Crime and Social Jusitce (Spring-Summer), p. 55.

Tracy, Charles A. 1979. "Police Function in Portland, 1851-1874 Part I," Oregon Historical Quarterly, LXXX (Spring), pp. 5-30.

Walker, Samuel 1976. "Police Professionalism: Another Look at the Issues," Journal of Sociology and Social Welfare, III (July), pp. 701-7T0.

White, Susan 1972. "A Perspective on Police Professionalization," Law and Society Review, 7 (Fal1), pp. 61-86. 


\section{B. Labor}

Gutman, Herbert 1965. "The Tompkins Square 'Riot' in New York City on January 13, 1874: A Re-examination of $i$ ts Causes and its Aftermath," Labor History, 6 (Winter), pp. 44-70.

Miller, Sally M. 1975. "Milwaukee: Of Ethnicity and Labor," in Bruce M. Stave (ed.), Socialism and the Cities, Port Washington, N.Y.: Kennikat Press, pp. 4T-7T.

Preston, William 1971. "Shall This Be All? U.S. Historians Versus William D. Haywood Et al." Labor History, 6, pp. 3-43.

Tobin, Eugene M. 1979. "Direct Action and Conscience: The 1913 Paterson Strike as an Example of the Relationship Between Labor Radicals and Liberals," Labor History, 20 (Winter), pp. 73-88.

Trible, William E. 1978. "Haymarket Riot: May 4, 1886," FBI Law Enforcement Bulletin, 47 (May), pp. 16-22.

\section{Politics, Economics, and Society}

Aptheker, Herbert 1979. "Anti-Sovietism in the United States: An Overal1 View," Political Affairs (June), pp. 1-4.

Adamek, Raymond J. and Jerry M. Lewis 1975. "Social Control Violence and Radicalization: Behavioral Data," Social Problems, 22, 5, pp. 663-674.

Barton, Allen H. 1968. "The Columbia Crisis: Campus, Vietnam, and the Ghetto," Public Opinion Quarterly, 32 (Fal1), pp. 333-351.

Chambliss, William J. 1964. "A Sociological Analysis of the Law of Vagrancy," Social Problems, 12 (Summer), pp. 67-77.

1971. "Vice, Corruption, and Power," Wiscons in Law Review, 4, pp. 1130-1155.

Gibbons, Don C. 1978. "Radical Criminology Revisited: Social Interests, Social Change, and the Criminal Justice System," Paper Presented at the Pacific Sociological Association Meetings in Spokane, Washington.

Hedrick, Paul C. 1919. "The I.W.W. and Mayor Hanson," The Unpartizan Review, xi i (July-December), pp. 35-45. 
Holbrook, Steward 1958. "Some Notes on an 01d School Radical," The Call Number (Fa11), pp. 4-7.

Holsinger, M. Paul 1977. "Patriotism and the Curbing of Oregon's Radicals, 1919-1937," Paper Presented to the Seventeenth Annual Conference of the Western History Association, Portland.

Homans, George C. 1964. "Bringing Men Back In," American Sociological Review, 29 (December), pp. 809-818.

Hopkins, Andrew 1975. "On the Sociology of Criminal Law," Social Problems, 22, 5, pp. 608-619.

1979. "Pressure Groups and the Law," Contemporary Crises, 3 (January), pp. 69-82.

Huntington, Samuel P. 1974. "Post-Industrial Politics: How Benign Wil1 It Be?" Comparative Politics, 6 (January), pp. 163-191.

Krasner, Stephen D. 1979. "A Statist Interpretation of American 0 il Policy Toward the Middle East," Political Science Quarterly, 94 (Spring), pp. 77-97.

Lippmann, Walter and Charles Merz 1920. Untitled report, New Republic, supplement (August 4), pp. 1-42.

Lipsky, Michael 1968. "Protest as a Political Resource," American Political Science Review, 62 (December), pp. 1144-1158.

Miller, Walter B. 1973. "Ideology and Criminal Justice Policy: Some Current Issues," The Journal of Criminal Law and Criminoiogy, 64 (June), pp. 14T-162.

Molotch, Harvey 1979. "Media and Movements," in John McCarthy and Mayer Zald (eds.), Social Movements and Resource Mobilization, Beverly Hills, Calif.: Sage Publications.

Oberscha11, Anthony 1970. "Group Violence," Law and Society Review, 5 (August), pp. 67-92.

Paxson, Frederic L. 1939. "The Great Demobilization," The American Historical Review, XLIV (January), pp. 237-251.

Sptizer, Steven 1975. "Toward a Marxian Theory of Deviance," Social Problems, 22 (June), pp. 638-651.

Wrong, Dennis 1961. "The Oversocialized Conception of Man in Modern Sociology," American Sociological Review, 26 (Apri1), pp. 183193. 
VI. NEWSPAPERS AND MAGAZINES

A. Seattle

Daily Times

Post-Intelligencer

Star.
Sun

Union-Record

B. Portland

News

The Portland Telegram

Oregonian

Oregon Journal

C. New York

New York Times

Wall Street Journal

D. Other Cities

Bremerton News (Bremerton, Washington)

Industrial Worker (Seattle and Spokane, Washington)

Solidarity (Chicago)

Spokane Spokesman Review (Spokane, Washington)

The Evening Telegram (New Bedford, Massachusetts)

Tribune (Chicago)

VII. INTERVIEWS

A. In Person

Frank Braillard, former Seattle police officer, interviewed by Bruce Rayborn, Portland police officer, in Seattle, Washington, March 10, 1979.

Julia G. Ruuttila, labor activist, interviewed by Dennis E. Hoffman, in Portland, Oregon, on July 1, 1979. 


\section{B. By Phone}

Unidentified Member of Civil Liberties Committee interviewed by Dennis E. Hoffman in Portland, Oregon, on July 2, 1979. 
APPENDIX A

POLICE - IWW ENCOUNTERS SHEET

Source:

Page _ Column

Type of Report: News article_ Editorial_ Advertisement Notice Other

General Description ( $1-3$ sentences describing encounter)

Type of Event:

Demonstrations General Strikes

Parades - Meetings between police \& IWW

Assemb Ties, crowds, mobs - IWW meetings

Gatherings

Rallies

Strikes

- Special celebrations

- Police raids

- Other (specify)

Police Actions:

Isolate and ignore

Mass arrests $(+10)$

Deny workers access to an area -

Arrests

Seizure of property

Searches

Order to disperse

No. Police Shootings:

Victim precipitated Yes__ No _

No. Police Killings: 
No. Police Assaults:

Harrassment (verba1)

Harrassment (physical)

Number of Personal Injuries

Property Damage

Objective of Police Action:

Police Strategy:

Reactive (IWW initiated)

Proactive (police/mayor or council-initiated)

Preventive

Numbers at Scene:

City Police

Other Police

IWW

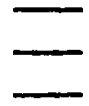

Names of Leaders:

City Police

IWW

Geographical Location:

Type of Building:

Warehouse

Audi tori um

Private Residence

Municipar Bui iúing

Union Meeting Half

Police Headquarters

other (specify) 
APPENDIX B

POLICE INTERVIEW GUIDE

1. How much contact did you have with the I.W.W. When you were a police officer? (If respondent answers "a lot," ask: What do you mean by "a lot"?)
a) Do you recall any particular police cases involving the I.W.W. in which you were a participant? If so, please describe one or two of these cases.

2. To what extent, if at all, did you feel that you had to pay attention to city politicians or busienssimen in your job?
a) Did either city politicians or businessmen influence how you handled labor disputes involving the I.W.W.?
b) As far as you know, were there any differences in what the Republican politicians wanted the police to do with the I.W.W. compared to what the Democrats wanted them to do?

3. Would you say there was much corruption in the police department when you were on the force? If so, what kinds of corrpution were there?
a) Were there any efforts to get rid of some of the corruption when you were on the force?
b) Did any of the reform activities have anything to do with the I.W.W.?
4. Did you feel free to administer the law on the street in situations involving the I.W.W. as you saw fit? If not, why didn't you feel free to do things as you wanted to?
5. Did you notice any changes in the police department that were made because of the I.W.W.? (Examples of changes: increases in size of force, increases in salary, more training, more specific plans for handling labor problems, etc.)

6. What tactics did the police use to handle strikes, riots, street meetings, and other types of I.W.W. gatherings?
a) Did the police use things such as "red" files or "plants" (i.e., undercover police officers)? 
7. What tactics, if any, did the police use to "prevent" I.W.W. organizing activities?
a) Did tine work that the police were doing with juveniles (e.g., supervising juvenile activities in skating rinks, shooting galleries, and the like) have anything to do with the I.W.W.?

8. Were you ever involved in a police raid on an I.W.W. hall? If so,
a) What happened?
b) What was the purnose of the raid?

9. Do you think most of the general public supported the way that the police handled the Wobbly situation?
a) Were there certain groups in the city that were very critical of the way that the police handled the labor disputes involving the I.W.W.? Did any of these groups have an important influence on police behavior? supportive of the police? Were there any groups that were
b) Did the newspapers have any influence on police response to the I.W.W. difficulties?

10. Today, in 1979, professionalism is a very popular idea. Was there much emphasis on "professionalizing" the police when you were on the force?
a) What was done to professionalize the force?
b) Do you think that these changes (related to professionalism) made a difference in how the police responded to the I.W.W.?

11. Many books have been written about the I.W.W. What was the I.W.W. really like? What were the goals and objectives of the I.W.W.?
a) Some people have argued that the I.W.W. posed a challenge to the institution of private property and to the entire "free enterprise" system in the United States. How do you feel about this statement? Is this the way you felt when you were a police officer?

12. As you know, there was quite a bit of violence in places like Everett and Centralia, Washington. Was there much police violence against the I.W.W. in (Seattle/Portland)? 
a) Were there certain events, periods, or years in which you think that police violence against the I.W.W. Was especially high? When? Why?

b) Did you ever "rough up" or shoot a Wobbly? If so, why did you do it? 